\begin{abstract}
UniVERsidade de São Paulo
FaCUldade de Filosofia, Letras e CiênCias Humanas

DEPARTAMENTO DE LINGUÍSTICA

Programa de Pós-GraduaÇão em Semiótica e Linguística Geral
\end{abstract}

FERNANDA ROSA DA SILVA

FOCO E RELAÇÕES DE ESCOPO:

UM ESTUDO DE CASO NO PORTUGUÊS BRASILEIRO

Versão corrigida

São Paulo 
FERNANDA ROSA DA SILVA

\section{FOCO E RELAÇÕES DE ESCOPO: UM ESTUDO DE CASO NO PORTUGUÊS BRASILEIRO}

Dissertação apresentada ao Programa de Pós-Graduação em Semiótica e Linguística Geral do Departamento de Linguística da Faculdade de Filosofia, Letras e Ciências Humanas da Universidade de São Paulo, para obtenção do título de mestre em Linguística.

Orientador: Prof. Dr. Marcelo Barra Ferreira

Ass:

Versão corrigida

São Paulo - 2012 
A Maria Aparecida e José Carlos, meus pais Ao Carlos Fernando e Lucas Fernando, meus irmãos Ao Tiago, meu sobrinho querido! 


\section{AgRADECIMENTOS}

Agradeço primeiramente a Deus, por sempre estar presente em minha vida, cuidando de mim, iluminando meus passos e me dando sabedoria para fazer escolhas, suportar as dificuldades e vencer os desafios postos em meu caminho.

Agradeço imensamente ao meu querido orientador, Marcelo Ferreira, por ter acreditado em mim e por ter investido tanto de seu tempo em minha formação. Apesar de todas as minhas limitações e do tão pouco conhecimento em semântica formal, ele pacientemente me conduziu a este mundo fascinante dos $\lambda$. Sou muito grata por ser tão criterioso e rigoroso na discussão de meu trabalho, pois graças a essa exigência e ao seu comprometimento profissional com a pesquisa científica, pude desenvolver essa dissertação.

Não posso deixar de reservar um agradecimento especial à Ana Müller, que foi a responsável por abrir as portas da USP para mim. Se não fosse ela em meu caminho, jamais teria tido a oportunidade de ingressar nesta universidade tão bem conceituada. Por algum motivo que não sei bem, ela acreditou em mim e apostou que poderia crescer e desenvolver um bom trabalho na área semântica formal. Agradeço pelas aulas, pelas discussões no grupo, pelas contribuições ao meu trabalho e especialmente pelo carinho e atenção que sempre dedicou a mim e a minha pesquisa.

Agradeço à Profa. Esmeralda Negrão, pelas valiosas contribuições no meu exame de qualificação. Também sou muito grata pela sua pesquisa com quantificadores que me inspirou e me levou a trilhar por estes caminhos. Agradeço muito ao carinho e ao cuidado que dispensou e dispensa não só a mim, mas a todos os alunos do departamento. Costumo dizer que ela é a "maezona" da linguística.

Agradeço aos professores do DL que ministraram disciplinas das quais tive a honra de participar: Elaine Grolla, Marcello Modesto, Ana Müller, Esmeralda Negrão. O conhecimento que adquiri com cada um desses profissionais foi imprescindível para a minha formação e para o desenvolvimento do meu trabalho. E através deles, agradeço a todos os professores do Departamento de Linguística.

Ainda em relação à formação, não posso deixar de registrar aqui meu agradecimento a minha professora da graduação, Clarice Assalim, que sempre me incentivou e me deu as primeiras dicas para ingressar no mestrado na USP.

Agradeço a CAPES pelo apoio financeiro

Agradeço à Érica, ao Robson e ao Bem Hur pela competência e dedicação com que 
sempre desenvolvem seu trabalho e pela ajuda aos trâmites burocráticos. Se não fosse eles, com certeza sofreria muito mais com a burocracia.

Sou muito grata às amizades verdadeiras que pude fazer nesses dois anos. Aos amigos do grupo de semântica formal. Lídia, minha companheira de estudos, de viagens e com quem eu pude compartilhar momentos de angústia e desespero, não só relacionados à pós-graduação, mas à vida. Tenho certeza que a amizade que desenvolvemos é pra toda a vida. Luciana, muito obrigada pela amizade, pela companhia nos congressos e pelos nossos momentos de descontração e alegria. Roberlei, meu amigo e companheiro do Helena's Garden. Quanto eu o aluguei com minhas dúvidas de semântica, e com os procedimentos da pós em geral. E ele atencioso, como um gentleman que é, sempre esteve disposto a me ajudar. Não posso me esquecer do meu amigo sintaticista querido, Marcus Lunguinho, pela companhia de sempre, pelas idas ao supermercado nos momentos de fuga à tese e é claro, pela ajuda com a sintaxe, já que sempre me enroscava. Agradeço à Lara, Wania, Michel, Renato Lacerda, Indaiá, Paula, Karin, Jéssica, Victor e demais colegas da pós pelas conversas e pela companhia.

Saindo um pouco deste mundo da linguística, agradeço ao Víctor pela amizade, companheirismo e cumplicidade de sempre. Agradeço pelo seu incentivo e pela sua força que me impulsionou a trilhar pelos caminhos da pesquisa. Agradeço também por sempre estar disposto a ouvir minhas lamentações e por sempre ter uma palavra amiga e de carinho.

Agradeço a minha amiga e irmã, Monica (não de sangue, infelizmente), por sempre acreditar em mim e por acompanhar toda a minha trajetória, desde criança, chorando comigo nos momentos difíceis e comemorando as minhas conquistas.

Agradeço à Lucia, Selma, Cleusa, André, Robson, Levi, Rosa Helena, Grazi, Roberta, Michele, Adriana e a todos os outros amigos que sempre me acompanham e que me proporcionaram momentos de descontração, alegria e reflexões, fora do universo linguístico. Muito obrigada pela amizade e carinho!

Por fim, mas longe de ser menos importante, sou eternamente grata aos meus pais, José Carlos e Maria Aparecida pelo apoio e incentivo de sempre. A eles dedico este trabalho, pois se não fosse o esforço e sacrifício que dispensaram a mim, durante toda a minha vida, com certeza não chegaria até aqui. Agradeço aos meus irmãos Carlos e Lucas e é claro, ao meu sobrinho querido, Tiago, que me faz retornar ao fascinante mundo infantil das brincadeiras e das fantasias. Agradeço pelos abraços, beijos, carinho e amor sinceros que sempre me dispensou. Agradeço também às minhas filhinhas de quatro patas: Talita, Meg, Pitty e Belinha, pelo amor, carinho e companhia incondicionais! 
"... o tempo é um tecido invisível em que se pode bordar tudo, uma flor, um pássaro, uma dama, um castelo, um túmulo. Também se pode bordar nada. Nada em cima de invisível é a mais sutil obra deste mundo, e acaso do outro." 


\section{RESUMO}

Este trabalho investiga os efeitos semânticos e pragmáticos de um tipo específico de foco - que chamamos foco sobreinformativo - e como ele afeta relações de escopo entre sintagmas quantificadores em português brasileiro. Discutimos como a estrutura informacional e o escopo de quantificadores interagem, com atenção especial a vários tipos de quantificadores, como universais, existenciais, e cardinais.

Relações de escopo em português brasileiro foram investigadas em Negrão (1999), que concluiu trata-se de uma língua bastante rígida nesse aspecto, não permitindo inversão de escopo na maioria dos casos. Tal trabalho, entretanto, se restringiu a contextos neutros. Nosso objetivo é investigar como o foco sobreinformativo pode afetar essa aparente rigidez.

No decorrer do trabalho fornecemos análises sintáticas e semânticas detalhadas da interação entre quantificação e focalização e uma caracterização pragmática dos contextos em que o foco sobreinformativo é lícito.

Palavras-chave: inversão de escopo; foco; tópico, estrutura da informação; perguntas. 


\begin{abstract}
This work investigates the semantic and pragmatic effects of a specific kind of focus - which we call over-informative focus - and how it affects scope relations among quantifier phrases in Brazilian Portuguese. We discuss how information structure and quantifier scope interact paying attention to many types of quantifiers such as universals, existential and cardinals.
\end{abstract}

Scope relations in Brazilian Portuguese were investigated by Negrão (1999), who have concluded that the language is very rigid disallowing scope inversion in most cases. Her work, however, was restricted to neutral (out-of-the-blue) contexts. Our goal is to investigate how over-informative focus affects this apparent rigidity.

Throughout this work, we give a detailed syntactic and semantic analysis of the interaction between quantification and focalization and a pragmatic characterization of contexts in which over informative focus is licit.

Key-words: scopal inversion; focus; topic, informational structure; questions. 


\section{SUMÁRIO}

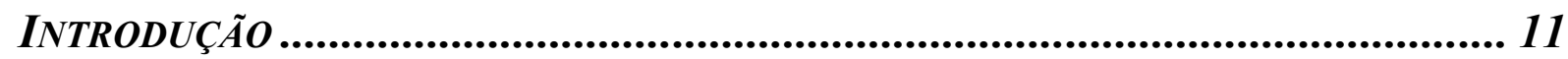

CAPÍtulo 1: ESCOPO E FoCALIZAÇÃo No PoRTUGUÊS BRASILEIRO................ 13

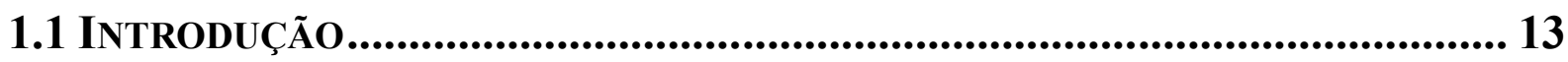

1.2 QUANTIFICAÇÃ̃o E ESCOPO........................................................................ 14

1.2.1 Teoria de CheCagem: Beghelli \& Stowell (1997) ....................................... 14

1.2.2 RELAÇÃo DE ESCOPO ENTRE QUANTIFICADORES EM PORTUGUÊS: NEGRÃo (1999). 17

1.3 FOCALIZAÇÃO E ESTRUTURA INFORMACIONAL ....................................... 20

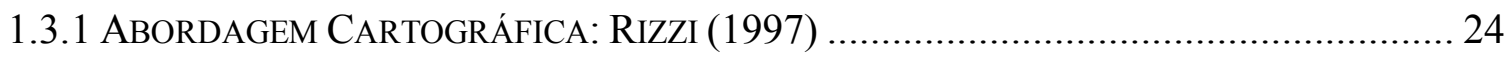

1.3.2 FocalizaÇÃo no Português Brasileiro: Mioto (2003) .................................... 28

1.4 SintaXe E SEMÂnTICA do Foco Sobreinformativo ......................... 31

1.5 RESUMO dO CAPÍTULO ......................................................................... 38

CAPÍtULO 2: Foco SOBREINFORMATIVO E ESTRATÉGIAS DE RESPOSTA............ 41

2.1 INTRODUÇÃ̃O ..................................................................... 41

2.2 As Máximas Conversacionais: Grice (1975) .............................. 43

2.3 Estratégias de Perguntas e Respostas: Roberts (1996) ................ 45

2.4 Tópico Contrastivo 1: BüRIng (1999) ..................................... 51

2.5 Tópico Contrastivo 2: Büring (2003) ........................................... 56

2.6 Estratégias de Respostas Sobreinformativas em PortuguêS ....... 61

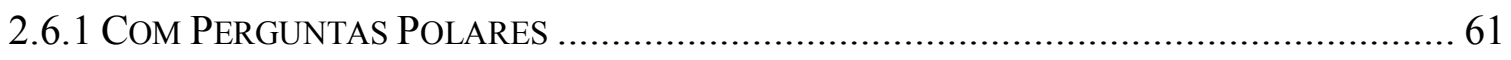

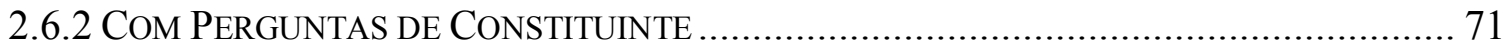

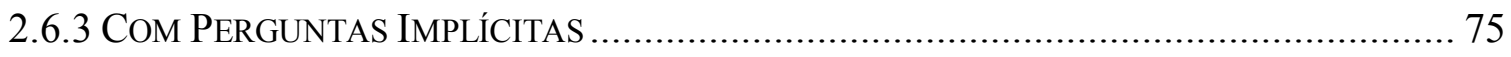

2.7 ESTRATÉGIAS DE RESPOSTA SOBREINFORMATIVA E INVERSÃO DE ESCOPO77

2.8 RESUMO do CAPÍtULO ............................................................ 79 
CAPÍTULO 3: FoCO SOBREINFORMATIVO E INVERSÃO DE ESCOPO........................ 81

3.1 INTRODUÇÃ

3.2 ANÁLISE DOS DADOS .......................................................... 81

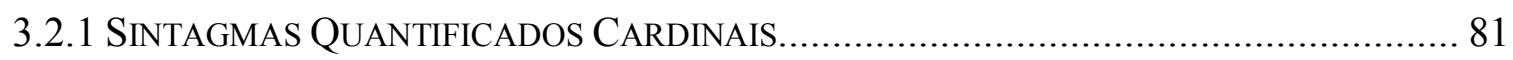

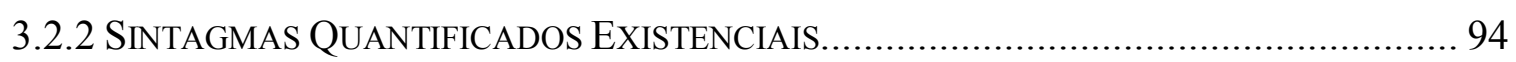

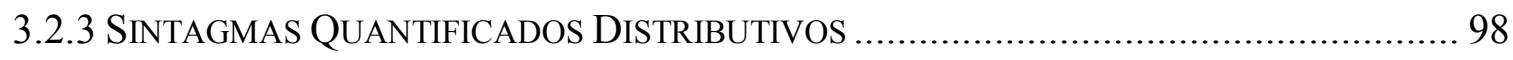

3.3 RESUMO do CAPÍtulo ........................................................ 102

CONSIDERAÇÕES FINAIS.................................................................. 104

APÊNDICE

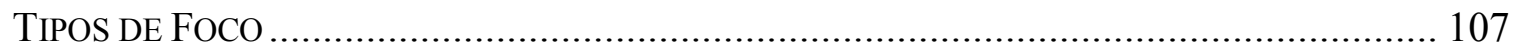

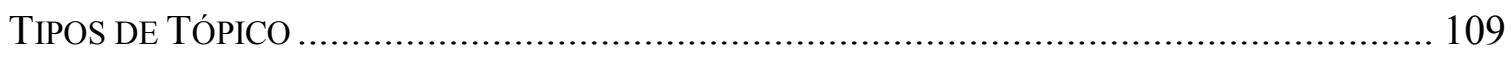

REFERÊNCIAS BIBLIOGRÁFICAS............................................................... 110 


\section{INTRODUÇÃo}

O presente trabalho tem como tema principal as relações de escopo entre quantificadores em sentenças do português brasileiro (PB). Mais especificamente, o objetivo desta pesquisa é investigar os efeitos semânticos e pragmáticos de um tipo especifico de foco, a que chamamos de foco sobreinformativo nas relações de escopo em sentenças declarativas do PB. Nossa proposta é buscar compreender de que maneira as noções semânticopragmáticas da estrutura informacional interagem com a noção sintático-semântica de escopo atrelada a sintagmas quantificadores de diversos tipos como: universais (todo), cardinais (dois), cardinais modificados (mais de, menos de) e existenciais $(\operatorname{algum}(s))$.

Relações de escopo entre sintagmas quantificadores tem sido objeto de estudo de diversos pesquisadores e em especial, no PB, destaca-se a pesquisa de Negrão (1999), na qual a autora conclui que nossa língua se mostra bastante rígida no que diz respeito à inversão de escopo. Porém, seu trabalho restringiu-se à análise de sentenças em contextos neutros. A proposta deste trabalho é verificar a possibilidade de inversão de escopo em sentenças com mais de um sintagma quantificado inseridas em contextos marcados pelo foco sobreinformativo.

A hipótese é de que, apesar do Português Brasileiro ser uma língua voltada para o discurso, conforme afirma Negrão, e priorizar interpretações das sentenças a partir da estrutura fornecida pela sintaxe aberta, em contextos marcados por foco, poderá haver inversão de escopo na estrutura lógica em sentenças que contenham quantificadores nas posições de sujeito e objeto. Ressaltamos que o foco tratado aqui será o foco in situ, elemento que se mantém em sua posição sintática original e que precisa de um acento prosódico para ser identificado. Não serão observadas sentenças com focalização geradas a partir de deslocamento, como clivadas, por exemplo.

Para verificar a consistência desta hipótese, foram testadas sentenças com quantificadores dos tipos citados acima nas posições de argumento externo e interno do verbo em contextos de foco. Essas sentenças foram examinadas a partir da criação de contextos específicos que privilegiassem a focalização. Os testes foram realizados a partir da aplicação de ferramentas lógicas baseadas numa teoria semântica composicional (cf. Heim e Kratzer (1998)) e da intuição de falantes nativos da língua.

O trabalho está organizado da seguinte forma: no capítulo 1, será proposta uma 
primeira análise sintática e semântica de inversão de escopo, a partir de um breve panorama das teorias de escopo e focalização mais gerais e especificamente aquelas que trataram do português brasileiro. No capítulo 2, serão analisadas sentenças do PB em contextos marcados por foco sobreinformativo, com base em teorias pragmáticas e de interface semânticopragmáticas que se debruçaram sobre os fenômenos estudados. Estes fenômenos serão observados nas respostas sobreinformativas e suas peculiaridades serão importantes para a análise das relações de escopo. Capítulo 3 está reservado para análise dos dados em sentenças que apresentem interação com diversos tipos de sintagmas quantificados em contextos marcados pelo foco sobreinformativo. Por fim, serão apresentadas as considerações e conclusões da presente pesquisa. 


\section{Escopo e FoCAlizaÇão No PORTuguês Brasileiro}

\subsection{INTRODUÇÃ̃O}

Neste capítulo, a partir de uma breve exposição das teorias que servem de background para a presente pesquisa, propomos uma análise sintática e semântica para inversão de escopo no português brasileiro. Tal análise vai ao encontro de nossa hipótese de que em contextos marcados por foco, mais especificamente, por foco sobreinformativo, poderá haver inversão de escopo na estrutura lógica de sentenças que contenham quantificadores nas posições de sujeito e objeto.

O capítulo está dividido em três partes. Na primeira parte, apresentamos algumas teorias sobre quantificação e escopo, em especial, a teoria de checagem de Beghelli \& Stowell (1997). Tal teoria propõe que escopo de quantificadores não ocorre de maneira uniforme e cada tipo de quantificador tem uma posição diferenciada na árvore sintática. Ainda, dentro das teorias de quantificação e escopo, destacamos a proposta de Negrão (1999) para escopo de quantificadores em PB que, a partir da teoria de Beghelli e Stowell, defende que o português brasileiro é uma língua bastante rígida no que diz respeito à inversão de escopo. O PB prefere manter em LF (forma lógica) a mesma estrutura sintática da sintaxe aberta ou PF (forma fonológica).

A segunda parte do capítulo é reservada para a apresentação de alguns elementos básicos sobre focalização e estrutura informacional. Nesta, são dadas definições de elementos discursivos como foco e tópico (cf. Halliday (1967); Zubizarreta (1998); Erterschik-Shir (2007)). Também é feita uma breve apresentação da Cartografia de Rizzi (1997), proposta que subdivide a categoria $\mathrm{CP}$ em diversas categorias funcionais, dentre as quais FocP, para constituintes com traço de foco e TopP, para constituintes com traço de tópico. Após, serão apresentadas a proposta sintática para constituintes focalizados no PB de Mioto (2003), que defende que no PB focos contrastivos ocupam uma posição mais alta na árvore sintática do que focos meramente informacionais. Na última seção, propomos uma estrutura sintática que une a teoria de checagem para sintagmas quantificados de Beghelli \& Stowell (1997) (e sua aplicação no PB a partir de Negrão (1999)) com a proposta de Rizzi (1997) para elementos de tópico e foco, assim como a proposta de Mioto (2003) para focos contrastivos e 
informacionais em PB. Então, apresentaremos uma proposta de análise sintática e semântica inversão de escopo em uma sentença com dois sintagmas quantificados.

\subsection{QUANTIFICAÇÃO E ESCOPO}

Relações de escopo entre sintagmas quantificadores sempre foram alvo da atenção de linguistas na tradição gerativa. Sobretudo a partir do trabalho seminal de May (1977), muito se descobriu sobre o comportamento sintático-semântico dessas expressões e diversas teorias foram elaboradas tendo as relações de escopo como pano de fundo (ver Hornstein 1995 para discussão). Para este estudo, destacamos a Teoria de Checagem, de Beghelli \& Stowell (1997), que será apresentada brevemente na próxima seção.

\subsubsection{Teoria de Checagem: Beghelli \& Stowell (1997)}

A Teoria de Checagem de Beghelli \& Stowell (1997) (ver também Beghelli 1995) apresenta um diferencial em relação às várias outras teorias que se debruçaram sobre os fenômenos de escopo. Nesta, a estrutura hierárquica das relações sintáticas é fundamental na definição das relações de escopo e essas relações não se dão de maneira uniforme com todos os quantificadores. O estudo dos autores os levou à seguinte classificação (damos aqui exemplos das contrapartes mais óbvias dos originais em inglês):

- QPs negativos (NQPs): não, ninguém; ${ }^{1}$

- QPs distributivos universais (DQPs): todo, cada;

- QPs de contagem (CQPs): mais de dois, um terço, metade;

- QPs denotadores de grupo (GQPs): um, algum, alguns, dois (dentre outros).

Beghelli e Stowell apresentam uma teoria híbrida entre a proposta de May (1977, 1985), segundo a qual qualquer quantificador pode se mover através de QR (alçamento de quantificador), e a proposta de Hornstein (1995), segundo a qual nenhum quantificador se move. Os autores defendem que certos tipos de QPs podem tomar escopo em sua posição de caso e outros QPs devem mover, em LF, para distintas posições de escopo reservadas para eles. Cada tipo tem uma posição de escopo designada, definida na estrutura hierárquica de

\footnotetext{
${ }^{1} \mathrm{QP}:$ abreviatura de sintagma quantificado em inglês.
} 
sintagmas da oração como a abaixo ${ }^{2}$ :

(1)

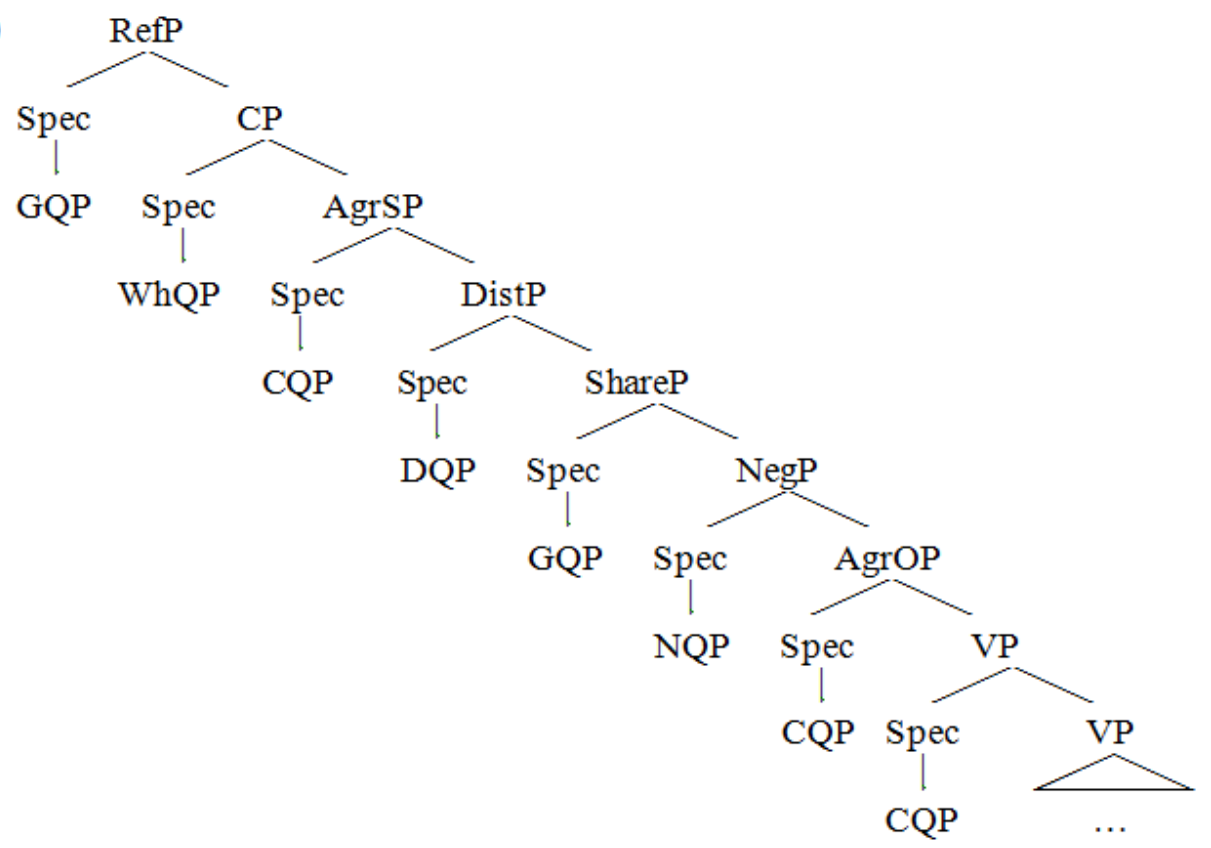

De acordo com esta teoria, os QPs se movem para posições distintas, a fim de checar seus traços. A ambiguidade em sentenças com interação de QPs se dá pela possibilidade de um mesmo sintagma quantificado poder ocupar mais de uma posição na estrutura hierárquica proposta pelos autores. Um GQP, por exemplo, pode ser ambíguo ao interagir com outro QP, pois este tipo de sintagma pode ocupar duas posições na estrutura: Spec de ShareP, quando apresenta um traço [+ existencial], ou Spec de RefP, quando apresenta, além do traço existencial, um traço [+ referência de grupo], que indica que o QP se refere a um grupo específico. A sentença abaixo, em inglês, pode apresentar duas leituras.

(2) Every student read two books. ${ }^{3}$

A primeira leitura possível é a de escopo linear, em que o DQP "every student" ccomanda "two books", em que cada aluno leu dois livros distintos. Em outra leitura, de escopo inverso, o GQP "two books" c-comanda "every students". Esta leitura é de que existem dois livros e estes livros foram lidos por todos os alunos.

Tal ambiguidade se dá pelo motivo de que enquanto o DQP pode ocupar apenas uma

\footnotetext{
$2 \mathrm{Na}$ estrutura, as abreviaturas das categorias são: $\mathrm{RefP}=$ sintagma referencial; DistP = sintagma distributivo; $\mathrm{ShareP}=$ sintagma indefinido ou quantificador existencial de eventos.

${ }^{3}$ Exemplo no $^{\circ}(4)$ de Beghelli \& Stowell (1997), p. 80.
} 
posição na árvore apresentada em (1), Spec de DistP, GQPs podem ocupar tanto a posição de Spec de ShareP, sob o domínio de DistP, quanto Spec de RefP, que se localiza acima de DistP. ${ }^{4}$ Se houver um GQP na posição de sujeito, como no exemplo abaixo, a sentença também é ambígua e pode apresentar tanto a leitura de escopo linear como a de escopo invertido.

(3) Two students read every book. ${ }^{5}$

Neste caso, a leitura de escopo invertido ocorre porque o GQP na posição de sujeito, segundo os autores, sofre reconstrução de sua posição de caso para a posição de Spec de ShareP. O DQP na posição de objeto, por sua vez, move-se para a posição de Spec de DistP, a fim de checar de traço [+ distributivo].

Um CQP, na posição de objeto, no entanto, não pode se mover para uma posição mais alta que um GQP na posição de sujeito, como demonstra o exemplo abaixo, dado por Beghelli \& Stowell.

(4) Some students visited more than two girls. ${ }^{6}$

Na sentença (4), só há uma leitura possível, a de escopo linear, em que existe um grupo de alunos e cada um visitou mais de duas meninas. Isto porque CQPs, segundo os autores, não necessitam checar traços, por isso se mantêm em sua posição de caso. O GQP "some students" mantém-se em sua posição de caso e, mesmo que sofra reconstrução para a posição de Spec de ShareP, terá escopo sobre o CQP na posição de objeto. Por isso, a leitura de escopo inverso não é possível nessa sentença.

Se a sentença apresentar dois GQPs, um na posição de sujeito e outro na posição de objeto, entretanto, as duas leituras são possíveis.

\footnotetext{
${ }^{4}$ Entre os tipos de DQPs, o DQP-every e o DQP-each, segundo Beghelli \& Stowell, apresentam algumas características diversas. Every, diferentemente de each, pode receber uma interpretação universal não distributiva, comportando-se essencialmente como All. Each, mas não every ocorre em construções de quantificador flutuante. Each tem uma interpretação distributiva forte, enquanto every pode ter uma interpretação coletiva universal. Every aceita ser modificado por almost, each não. A partícula "not" combina com uma variedade de quantificadores proporcionais, incluindo o every e o all, mas não combina com each. Every tem uma característica mais universal que each. Each, por sua vez, é um operador mais distributivo que every. Diante destas observações os autores concluem que each é um QP distributivo verdadeiro e every não. Each é obrigatoriamente distributivo e every é opcional, por isso pode assumir posições distintas na estrutura proposta por Beghelli \& Stowell.

${ }^{5}$ Exemplo (4)b de Beghelli \& Stowell (1997), p. 80.

${ }^{6}$ Exemplo (8) de Beghelli \& Stowell (1997), p. 83.
} 
(5) Five boys read two books. ${ }^{7}$

Neste caso, em inglês, pode-se ter a leitura de que existem cinco meninos que leram dois livros cada, leitura de escopo linear. Ou, ainda, de que dois livros foram lidos por cinco meninos, leitura de escopo inverso. Esta ambiguidade se dá pelo motivo de que GQPs podem ocupar duas posições distintas na árvore em (1). Se o GQP na posição de sujeito se mover para Spec de RefP e o GQP na posição de objeto, para Spec de ShareP, teremos a primeira leitura, de escopo linear. Porém, se "two books" se mover para a posição de Spec de RefP, por apresentar um traço [+ referência de grupo], teremos, neste caso, uma leitura de escopo inverso.

Desta teoria, o que será mais importante para a pesquisa é que os quantificadores podem assumir posições distintas na árvore. Alguns permitem escopo amplo, movendo-se para uma posição superior a sua posição original, enquanto outros não são capazes de se mover para uma posição mais alta na árvore e se mantém em sua posição de caso, como por exemplo, os CQPs. ${ }^{8}$

\subsubsection{Relação de escopo entre quantificadores em português: Negrão (1999)}

No Brasil, quanto à relação de escopo entre sintagmas quantificados, destaca-se o trabalho de Negrão (1999), que se baseia na teoria proposta por Beghelli e Stowell (1997). Este mostrou que as relações de escopo em PB parecem bastante rígidas, sobretudo no que diz respeito a sentenças SVO, em que um sintagma quantificado na posição sujeito parece quase sempre ter escopo sobre um sintagma quantificador na posição de objeto.

(6) Muitos alunos leram cinco textos. ${ }^{9}$

Negrão afirma que há apenas uma leitura possível para a sentença (6), diferentemente de uma sentença correspondente em inglês, que apresenta ambiguidade. Tal leitura é a de escopo linear, em que o sintagma quantificado na posição de sujeito, assim como na sintaxe aberta, ocupa uma posição superior ao GQP na posição de objeto também em LF. A leitura de

\footnotetext{
${ }^{7}$ Exemplo (13)b de Beghelli \& Stowell (1997), p. 86.

${ }^{8} \mathrm{Um}$ sintagma $\mathrm{S}_{1}$ tem escopo amplo em relação a $\mathrm{S}_{2}$ quando $\mathrm{S}_{1}$ está em uma posição que c-comande assimetricamente $S_{2}$. Um sintagma $S_{1}$, por outro lado, tem escopo estreito em relação a $S_{2}$ se $S_{1}$ está em uma posição em que seja comandado por $\mathrm{S}_{2}$.

${ }^{9}$ Exemplo (28)a de Negrão (1999), p. 159.
} 
escopo linear pode ser parafraseada por: para cada membro do grupo de alunos, que são muitos, existem cinco textos quaisquer que este tenha lido. A única possibilidade de leitura, segundo Negrão, se dá porque em PB, GQPs na posição de sujeito sempre se movem para a posição de Spec de RefP e não podem sofrer reconstrução para sua posição de origem, dentro de VP. Uma leitura em que existem cinco textos que foram lidos pelo grupo de alunos, para a autora, só é possível em uma sentença que apresente uma estrutura como a abaixo, que destaca a relação de escopo na sintaxe aberta, com o QP entre o verbo existencial "ter" e uma oração relativa.

(7) Tem cinco textos que muitos alunos leram. ${ }^{10}$

Outro exemplo dado por Negrão, em que não ocorre inversão de escopo em PB, é quando a sentença apresenta um DQP-todo na posição de objeto, interagindo com um GQP, como a sentença abaixo. ${ }^{11}$

(8) Um aluno diferente leu todo texto indicado para o curso. ${ }^{12}$

A sentença (8), de acordo com Negrão, possui apenas a leitura de escopo linear, em que o DQP-todo na posição de objeto não pode se mover, em LF, para uma posição mais alta do que o GQP na posição de sujeito. A única leitura possível é de que um aluno, fora do padrão, leu todos os textos que foram indicados para o curso. Tal impossibilidade de inversão de escopo ocorre, segundo Negrão, porque "todo" na posição de objeto em PB não se move para Spec de DistP. Mantém-se em sua posição de caso, sob o domínio do GQP na posição de sujeito, que se move para Spec de RefP.

A exceção apresentada no trabalho de Negrão, em que um quantificador na posição de objeto toma escopo amplo na sentença, ocorre apenas em construções que contenham o quantificador "cada" nessa posição. Este fenômeno pode ser explicado por características exclusivas de "cada", que apresenta uma marca forte de distributividade e sempre se move em LF para a posição de Spec de DistP. Veja o exemplo abaixo dado por Negrão (1999: 154):

\footnotetext{
${ }^{10}$ Exemplo (28)b de Negrão (1999), p. 159

${ }^{11}$ Negrão afirma que algumas sentenças com DQPs na posição de objeto em PB sem um modificador são agramaticais. Isto porque DQPs necessitam de um elemento sobre o qual possam exercer distribuição. Por este motivo, os exemplos utilizados nesta pesquisa com "todo" na posição de objeto serão apresentados com um modificador.

${ }^{12}$ Exemplo (31b) de Negrão (1999), p. 161
} 
(9) a. Mais de cinco alunos leram cada texto escrito por Chomsky.

b. Um aluno diferente leu cada texto escrito por Chomsky.

Nos casos acima, o DQP-cada na posição de objeto move-se para posição de Spec de DistP, acima do CQP "Mais de cinco alunos" que sofre reconstrução para sua posição de base.

Negrão não apresenta, em seu trabalho, sentenças com CQP do tipo "mais de três alunos" na posição de sujeito interagindo com o DQP-todo na posição de objeto. Porém, se assumirmos com ela que o DQP "todo" na posição de objeto não pode se mover para Spec de DistP e, consequentemente, c-comandar o CQP na posição de sujeito, uma sentença como a abaixo não poderá apresentar inversão de escopo em contexto neutro. Uma sentença como a abaixo, terá, portanto, apenas a leitura de que um grupo de alunos, cuja quantidade é maior que dois, leu todos os textos indicados para o curso.

(10) Mais de dois alunos leram todo texto indicado para o curso.

A previsão da autora parece estar de acordo com a intuição dos falantes, visto que a sentença (10) é considerada falsa em um contexto no qual para cada palestra do congresso, há um número de alunos, maior do que dois que reclamou desta palestra, sem que necessariamente os alunos sejam os mesmos.

Ainda, segundo Negrão, GQPs ocupando a posição de objeto não podem se mover em LF para a posição a partir da qual se tornam sujeito da predicação e ocupem a posição de Spec de RefP da estrutura proposta por Beghelli \& Stowell (1997).

(11) Alguns alunos leram dois textos reservados para o curso. ${ }^{13}$

Na sentença (11), não se espera que o QP “dois textos” tenha escopo sobre o QP “alguns alunos”. Segundo Negrão, a interpretação mais saliente, senão a única, é de que existe um grupo de alunos que leu dois textos. A explicação da autora é de que em PB, GQPs na posição de objeto não podem se mover em LF para uma posição em que sejam o sujeito da predicação. Isto porque essa posição, que para Beghelli e Stowell é a posição de Spec de RefP, em PB já está preenchida na sintaxe aberta pelo sujeito da sentença.

\footnotetext{
${ }^{13}$ Exemplo (31b) de Negrão (1999), p. 161.
} 
Todas estas constatações vêm corroborar com a tese central da autora de que o português brasileiro é uma língua voltada para o discurso e que, portanto, privilegia marcar na sintaxe aberta ou visível, propriedades que em outras línguas resultam dos processos ocorridos em Forma Lógica.

Apesar da importância deste estudo, nota-se que as relações de escopo foram estudadas apenas nos chamados contextos neutros, em que uma sentença inicia um discurso ou responde a uma questão (explícita ou implícita) do tipo “o que aconteceu?". Sabe-se, entretanto, que contextos marcados, em que o tópico da conversação é mais restrito, ou perguntas menos gerais estão em discussão, podem influenciar não só a prosódia como também a organização interna dos constituintes sentenciais (ver Erteschik-Shir 2007), o que leva a crer que possam afetar relações de escopo quando sintagmas quantificadores estejam envolvidos. Diante disso, na próxima seção, apresentaremos um pouco das teorias gerais de focalização e específicas do PB para, em seguida, apresentarmos um exemplo de inversão de escopo em português brasileiro.

\subsection{FOCALIZAÇÃO E ESTRUTURA INFORMACIONAL}

Estrutura informacional, termo introduzido por Halliday (1967), calcula as distinções de foco e pressuposição em relação a entidades do discurso. Os elementos presentes são foco e tópico e ambos podem ser identificados pelo teste questão/resposta (cf. Zubizarreta (1998)). O elemento que responde à questão corresponde a uma nova informação e recebe a função de foco. O elemento introduzido pela questão tem função de tópico e traz uma pressuposição ou informação dada pelo contexto. ${ }^{14}$

(12) A: Quem chegou?

B: O JOÃO ${ }_{\mathrm{F}}$ chegou.

Em (12), o sintagma representado pelas letras maiúsculas "O JOÃO” tem a função do foco na sentença $B$, isto porque traz ao contexto uma informação nova, requerida pela questão em A. Já a pressuposição de que "alguém chegou" trata-se de uma informação já presente na questão e é denominada de tópico. A este tipo de foco, que se limita a trazer a

\footnotetext{
${ }^{14}$ No final do trabalho, em apêndice, apresento uma tabela resumida com os principais conceitos de tópico e foco apresentados e discutidos.
} 
informação requerida, Zubizarreta denomina de foco de informação ou não-contrastivo ${ }^{15}$. Se assumirmos que toda sentença é formada pelo que é conhecido e o que é informação nova, conforme Chomsky (1971), que defende que para cada sentença existe um par (F,P), F de foco e P, pressuposição, então, as sentenças em geral apresentam um foco de informação. Zubizarreta apresenta uma estrutura de asserção (AS) para este tipo de foco como o exemplo abaixo:

(13) $\mathrm{A}_{1}$ : Existe $\mathrm{x}$, tal que $\mathrm{x}$ chegou.

$\mathrm{A}_{2}$ : O x tal que $\mathrm{x}$ chegou é [F o João].

$\mathrm{Na}$ estrutura acima, $\mathrm{A}_{1}$ representa a pressuposição e $\mathrm{A}_{2}$ a informação nova. Além do foco de informação, Zubizarreta apresenta outro tipo de foco, em que a resposta não representa a informação solicitada para o elemento dado pelo contexto e sim para um novo elemento.

(14) A: O João chegou?

B: O PEDROF chegou, (não o João).

Em (14), o falante ao ser questionado sobre "o João", responde que "o Pedro chegou", contrariando a informação solicitada. Focos como estes são chamados pela autora de contrastivos. Este tipo de foco tem a estrutura de asserção como segue:

(15) $\mathrm{A}_{1}$ : Existe $\mathrm{x}$, tal que $\mathrm{x}$ chegou.

$\mathrm{A}_{2}$ : É falso que o x (tal que x chegou) é o João \& o x (tal que x chegou) é [F o Pedro]

Foco contrastivo, como no exemplo acima, contém, em sua asserção uma negação, a qual identifica que a propriedade dada, no caso "x chegou", não pertence ao indivíduo em questão, “o João", mas sim a outro indivíduo que é inserido no discurso, "o Pedro". 16

Outra proposta para foco contrastivo é a de Erteschik-Shir (2007), que defende que a

\footnotetext{
${ }^{15} \mathrm{Na}$ verdade, Zubizarreta (1998) refere-se a este tipo de foco, como foco não-contrastivo. Foco de informação é denominado por Kiss (1998).

${ }^{16}$ Há ainda o foco classificado por Kiss (1998) por identificacional que tem o traço mais exaustivo. Esse foco tem uma interpretação do tipo $x$ e apenas $x$. Um exemplo de foco identificacional ou exaustivo pode ser visto abaixo:
}

(i) A: Quem chegou?

B: O JOÃO chegou, (e ninguém mais). 
estrutura informacional é formada por dois elementos primitivos: tópico e foco e destes são derivados todos os tipos de tópico e foco existentes nas línguas naturais. Ela define um sistema gramatical em que os constituintes de tópico e foco são marcados. Tal sistema pode apresentar uma estrutura complexa, que apresenta mais de uma operação. Foco contrastivo é um dos casos que, para a autora, apresenta uma estrutura complexa. Vejamos o exemplo abaixo, similar ao dado pela autora.

(16) A: Quem chegou, o João ou o Pedro?

B: O JOÃO $\mathrm{F}_{\mathrm{F}}$ chegou.

No contexto acima, o constituinte "O João", segundo Erteschik-Shir, tem a função de foco contrastivo. Isto porque na pergunta em A foi lançado no contexto um conjunto de indivíduos formado pelos elementos "João" e "Pedro". Deste conjunto, então, o falante, ao responder B, destaca "João" e elimina "Pedro". A autora defende que ocorre um processo de focalização dentro do conjunto designado. Foco contrastivo para Erteschik-Shir, então tem a função de focalizar um elemento de determinado conjunto definido pelo contexto e negar os demais elementos deste. Há, portanto, uma operação de focalização do elemento dentro do conjunto determinado, conforme a representação abaixo.

(17) $\left[\left\{\text { João }_{\text {foc }}, \text { Pedro }\right\}_{\text {top }}\right]_{\text {top }}[$ chegou $]$

Outro tipo de foco apresentado por Erteschik-Shir, que também possui uma estrutura complexa, é o foco restritivo. Neste, o falante destaca um elemento de certo conjunto, porém sem especificar seus elementos. Com isso, o falante responde sobre tal elemento sem necessariamente excluir os demais.

(18) A: Quais dos alunos chegaram?

B: O JOÃO chegou $_{\mathrm{T}}$.

No contexto em (18), o falante em B escolhe, dentro do conjunto de amigos, inserido no contexto pela questão em A, o indivíduo "JOÃO”. Ou seja, focaliza tal constituinte e dá informações sobre ele, sem se comprometer com os demais elementos do conjunto de amigos. Büring, em seus trabalhos de (1999) e (2003) defende que há necessidade de uma entonação peculiar para que a resposta em (18)B tenha a interpretação de que o falante dá informações 
sobre João e não se compromete com os demais. Sem tal entonação, a resposta (18)B parece ser exaustiva e a interpretação que temos é de que "João e ninguém mais chegou". ${ }^{17}$

Além do foco restritivo, Erteschik-Shir apresenta o tópico restritivo. A diferença deste para o foco restritivo é que enquanto no foco há uma pressuposição de que "alguém tem a propriedade em discussão", (no caso acima, a pergunta em (18)A carrega uma pressuposição de que "algum aluno chegou" e a informação requerida é "quem, dentro do conjunto determinado, chegou?"), no tópico restritivo, não há a pressuposição de que "existe pelo menos um elemento do conjunto que tenha a propriedade em questão". Veja abaixo:

(19) A: Os alunos chegaram?

B: O JOÃO chegou.

A diferença do exemplo acima para o anterior é que enquanto em (18)A, há uma pressuposição de que "algum aluno chegou" e o falante A quer saber "quem chegou" dentro deste conjunto de alunos, em (19)A a informação requerida é se os alunos chegaram ou não. Ou seja, a pressuposição de que "algum aluno chegou" não é válida para o último contexto. $\mathrm{O}$ falante, ao responder B, apresenta duas asserções: afirma que "algum aluno chegou" e este é “o João".

Büring (1999) denomina elementos como no exemplo dado acima, em (19), de tópico parcial. Isto porque, o falante ao responder B, (com uma entonação peculiar que veremos com mais detalhes no capítulo 2) dá uma resposta parcial à pergunta dada e não se compromete com informações sobre os demais elementos do conjunto de "alunos".

Um outro caso que apresenta uma entonação peculiar, diferente dos tópicos parciais de Büring e dos tópicos contrastivos ou restritivos de Erteschik-Shir, são respostas ocorridas a partir de contextos como abaixo.

(20) A: O João chegou?

B: TODO MUNDO chegou.

No contexto em (20), ao contrário do tópico restritivo de Erteschik-Shir e do tópico parcial de Büring, um elemento é dado e a resposta obtida corresponde ao conjunto do qual este elemento faz parte, "todo mundo". Enquanto em (19), o falante opta por dar informação

\footnotetext{
${ }^{17}$ Veremos a proposta de Büring para este fenômeno mais detalhadamente no capítulo 2.
} 
apenas de um elemento do conjunto: “João", em (20), o falante, ao ser questionado a respeito de um indivíduo, responde não só sobre ele, mas sobre todos os individuos que fazem parte do conjunto em questão. O constituinte que traz a informação nova em (20), o sintagma quantificado "todo mundo", apesar de certa maneira constrastar o conjunto todo com o elemento dado "o João", não nega tal elemento. Pelo contrário, responder que "todo mundo foi pra festa", acarreta que "joão", fazendo parte do conjunto em discussão, também tenha ido. Casos como esse, portanto, não podem ser considerados como um foco contrastivo que apresenta as características propostas por Zubizarreta (1998) ou Erteschik-Shir (2007), em que necessariamente o elemento dado no contexto deve ser negado. Nesse caso, pelo contrário, ao responder que "todo mundo chegou", o falante responde sobre o João, mas deixa claro que a propriedade de chegar não é exclusiva dele, mas pertence a todos os elementos do conjunto.

Contextos como o dado acima não são contemplados por nenhum dos conceitos até aqui apresentados. Por isso, consideraremos na presente pesquisa que o conceito de foco destes dados é diferente do foco contrastivo discutido pelos autores citados. O elemento focalizado não necessariamente deve negar o elemento dado no contexto e sim negar a exaustividade deste em relação à propriedade em discussão. Mais do que isso, tal constituinte traz informações além das requeridas. A este tipo de foco que dá informações além do solicitado, como no exemplo (20), denominamos foco sobreinformativo e o discutiremos mais profundamente mais adiante, nos demais capítulos.

Todos os casos de focos aqui apresentados (com exceção ao foco de informação): contrastivos, restritivos, parciais, e também o sobreinformativo, parecem necessitar de acentos prosódicos distintos. Diversas teorias atrelam esta peculiaridade a uma posição sintática específica do constituinte que recebe tal acento. A relação entre a prosódia peculiar que sentenças com o foco sobreinformativo apresentam e sua estrutura sintática, bem como sua composição semântica serão discutidas mais adiante. A seguir, veremos as teorias que se propõem a definir as posições sintáticas de elementos com traços discursivos de foco e tópico.

\subsubsection{Abordagem Cartográfica: Rizzi (1997)}

Para análise da estrutura sintática e identificação de elementos discursivos como foco e tópico na estrutura, tomamos como ponto de partida a teoria cartográfica dada por Rizzi (1997). Esta proposta divide o CP em diversas categorias funcionais: ForceP, TopP, FocP, FinP, tornando a periferia esquerda da sentença mais complexa. A categoria ForceP está reservada para identificar o tipo de sentença, se é uma interrogativa, uma declarativa, uma 
exclamativa, etc. Também é responsável por se relacionar com a estrutura superior: uma sentença matriz, para as sentenças encaixadas e o discurso anterior, para as sentenças matrizes. FinP identifica se a sentença é infinitiva ou finita e relaciona $\mathrm{CP}$ à projeção funcional anterior, IP. As outras duas categorias, TopP e FocP recebem elementos com características discursivas, a primeira para constituintes com traço de tópico e a última para foco. O sistema proposto por Rizzi, como o exemplo abaixo, segue o modelo da teoria xbarra, em que cada categoria projeta seu especificador e núcleo. ${ }^{18} 19$

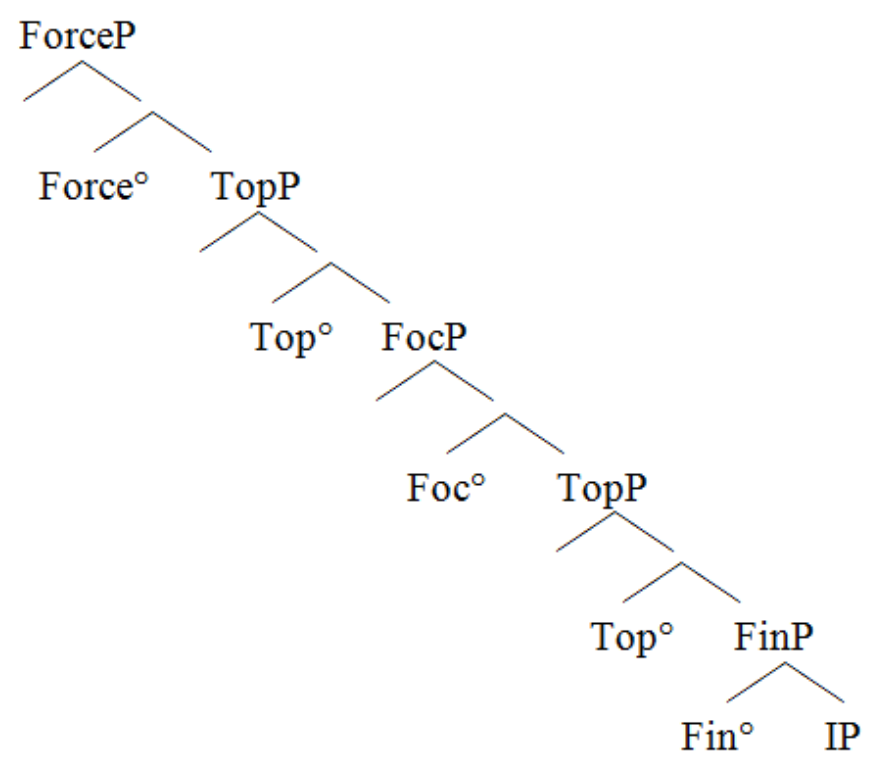

É importante ressaltar a existência de duas projeções TopP na estrutura de Rizzi, apresentada em (21). A justificativa para as duas projeções é que há línguas que podem apresentar mais de um constituinte de tópico. Constituintes de foco, no entanto, segundo o autor, não poderão ocorrer mais de uma vez em cada sentença e por isso há apenas uma projeção para elementos deste tipo. Ainda, as sentenças apresentam estruturas sintáticas que podem ter a projeção TopP tomando FocP como seu complemento, ou esta relação pode se dar de maneira oposta, em que FocP toma TopP como complemento. Abaixo, apresentamos alguns exemplos do italiano dados por Rizzi que demonstram estas duas possibilidades de estruturação:

\footnotetext{
${ }^{18}$ Sistema dado em (41) de Rizzi (1997), p. 297.

${ }^{19}$ A proposta de Rizzi e a de alguns outros autores apresentadas neste trabalho utilizam do termo IP para identificar a projeção funcional de flexão verbal da sentença. Assumimos, com Pollock (1989), que faz desdobramentos da categoria IP, que a categoria responsável pela flexão verbal corresponde à TP.
} 
(22) Il tuo libro, lo ho letto. ${ }^{20}$

"Seu livro, tenho lido ele."

(23) IL TUO LIBRO ho letto (, non il suo). ${ }^{21}$

"Seu livro eu li (, não o dele)."

$\mathrm{Na}$ sentença (22), o constituinte que aparece mais à esquerda da sentença tem a função discursiva de tópico, ou seja, representa a informação dada (a presença de uma vírgula logo após este constituinte dá pistas de que este se refere ao elemento já presente no discurso). Tal constituinte toma o restante da sentença, que representa a informação nova, como seu complemento. Na sentença (23), entretanto, o constituinte mais à esquerda tem a função discursiva de foco (identificada pelas letras maiúsculas) e toma o restante da sentença, que é a informação conhecida no discurso, como seu complemento. A partir dessas diferenças, Rizzi identifica, então, dois tipos de articulações entre constituintes de foco e tópico e as representa como a seguir. A estrutura em (24) representa a relação estabelecida em (22), em que o constituinte com função de tópico (XP) c-comanda o constituinte que contém o elemento focalizado. Já a estrutura em (25) corresponde à relação estabelecida em (23), oposta à anterior. $^{22}$

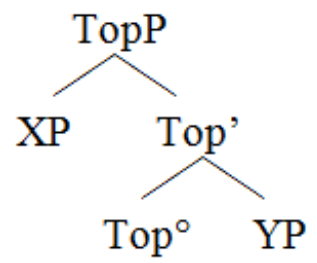

$\mathrm{XP}=$ tópico

$\mathrm{YP}=$ comentário

\footnotetext{
${ }^{20}$ Exemplo (3) de Rizzi (1997), p. 286.

${ }^{21}$ Exemplo (4) de Rizzi (1997), p. 286.

${ }^{22}$ Exemplos (5) e (6) de Rizzi (1997: 286, 287) respectivamente.
} 
(25)

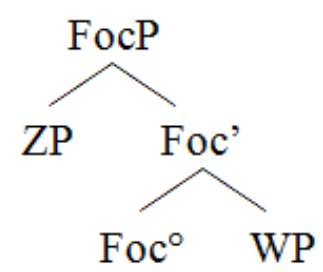

$$
\begin{aligned}
& \mathrm{ZP}=\text { foco } \\
& \mathrm{WP}=\text { pressuposição }
\end{aligned}
$$

Para a estrutura em (24), o XP localizado em Spec de TopP corresponde ao tópico. No exemplo em (22), o constituinte que ocupa esta posição é "Il tuo libro". A posição de YP representa o complemento de TopP e neste caso é ocupada por "lo ho letto", informação nova, ou comentário, como nomeia Rizzi. O núcleo desta projeção funcional, em (24), tem um traço [+top]. Na estrutura em (25), o ZP, por sua vez, representa um constituinte de foco e WP uma pressuposição, ou informação dada. No caso do exemplo dado em (23), "IL TUO LIBRO" ocupa a posição de ZP, especificador de FocP e "ho letto" WP, complemento de FocP. O núcleo desta projeção, em (25) é dotado de um traço [+foc].

O sistema cartográfico, como vimos, apresenta uma estrutura complexa para a categoria CP. Tal complexidade pode parecer distante de teorias que buscam descrever a estrutura sintática com maior simplicidade, como a proposta minimalista (cf. Chomsky (1995), ver também Hornstein, et al.(2005)). Cinque \& Rizzi (2008) afirmam, entretanto, que essa aparente incompatibilidade entre as propostas é, na verdade, uma divisão de trabalhos. Enquanto o Minimalismo busca descrever as estruturas da língua de uma forma mais simples, a proposta cartográfica, a partir das operações minimalistas, estuda de forma minuciosa os componentes da periferia esquerda da sentença e estas duas formas de investigação, segundo os autores, podem caminhar em paralelo de uma maneira consistente.

A seguir, apresentamos um trabalho que investigou a focalização no PB, de Mioto (2003). Este, para analisar quais as possibilidades de focalização em PB e qual a localização sintática do constituinte de foco, assume a proposta cartográfica de Rizzi (1997) e outros pesquisadores que assumem teoria similar para outras projeções funcionais, como, Belletti (2004), para a periferia de $v \mathrm{P}$, também chamada de periferia baixa. 


\subsubsection{Focalização no Português Brasileiro: Mioto $(2003)^{23}$}

Nesta seção, veremos com mais detalhes a proposta de Mioto (2003) (ver também Mioto (2001)) para a estrutura de sentenças do PB que contenham elementos discursivos como foco, em especial ao foco não informacional, que é presente nos dados deste estudo. $\mathrm{O}$ autor defende que no PB o constituinte que é interpretado como o foco contrastivo ou identificacional move-se para especificador de FocP na periferia esquerda da sentença, diferentemente do foco informacional, que ocupa uma posição mais baixa, na periferia esquerda de $v \mathrm{P}$, proposta defendida por Belletti (2001) e reformulada em Belletti (2004). Nesta proposta, a autora defende que a periferia esquerda de $v \mathrm{P}$ também apresenta uma estrutura complexa, dividida em categorias funcionais similares às presentes na periferia esquerda da sentença, apresentadas por Rizzi (1997). Belletti chega à conclusão, a partir de constatações empíricas, que em italiano, constituintes com função discursiva de foco de informação ocupam uma posição mais baixa que $\mathrm{CP}$, por isso defende a divisão de IP em categorias discursivas como TopP e FocP. A proposta de Belletti pode ser representada pela estrutura abaixo: ${ }^{24}$

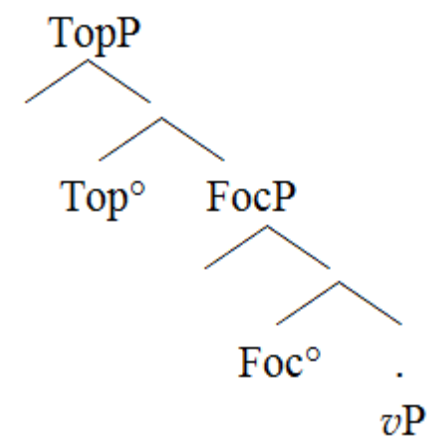

Mioto (2003), seguindo as propostas de Rizzi (1997) e Belletti (2001), identificou que no português brasileiro, focos identificacionais e contrastivos movem-se para a posição de Spec de FocP na periferia esquerda da sentença. Focos de informação, no entanto, movem-se para uma posição de Spec de FocP na periferia esquerda de $v \mathrm{P}$. O principal objetivo do autor foi explorar a ideia de que o constituinte focalizado obrigatoriamente deve se mover em LF.

Mioto identificou que o foco in situ na sintaxe aberta pode receber as três interpretações: de informação, contrastivo ou exaustivo. O foco deslocado na sintaxe aberta,

\footnotetext{
${ }^{23} \mathrm{O}$ autor assume os conceitos de foco informacional e contrastivo de Zubizarreta (1998) para analisar as estruturas sintáticas de sentenças do PB que apresentem constituintes com tais funções discursivas.

${ }^{24}$ Exemplo (19) de Belletti (2004), p. 25.
} 
no entanto, pode apenas receber a interpretação contrastiva ou exaustiva.

(27) a. O João comprou [F um carro e um avião].

b. Foi [F um carro e um avião] que o João comprou. ${ }^{25}$

Nestes exemplos dados pelo autor, podemos perceber que a sentença (27)a, com o constituinte focalizado in situ, pode ter uma leitura de foco meramente informacional, mas também pode ter uma leitura contrastiva, na qual a sentença poderia ser completada por: "e não um iate". Ainda, uma leitura exaustiva também pode ser apropriada para (27)a. Seria possível completá-la da seguinte maneira: "O João comprou um carro e um avião, nada mais além disso". Já a sentença em (27)b, que apresenta uma estrutura clivada, com o constituinte focado deslocado para uma posição entre a cópula e o complementizador, pode ter apenas uma destas duas leituras: exaustiva, "e nada mais" ou contrastiva, "e não um iate".

Para explicar as diferenças de interpretações entre focos contrastivos e informacionais, Mioto assume a teoria de Belletti (2001), que propõe a existência de uma periferia baixa, que se apresenta acima da projeção $v \mathrm{P}$ e interna a IP. Esta projeção apresenta as mesmas categorias da periferia esquerda de CP, entre elas a categoria FocP. Para o autor, então, se o constituinte focalizado estiver in situ e veicular meramente uma informação nova, este se move para o Spec de FocP interno à projeção IP. Se o constituinte focalizado estiver deslocado na sintaxe aberta e apresentar, portanto, uma interpretação exaustiva ou contrastiva, irá se mover para a Spec de FocP da periferia esquerda da sentença. O mesmo ocorre com foco in situ que apresenta uma interpretação não informacional (contrastiva ou exaustiva). $\mathrm{O}$ autor dá exemplos de análise como abaixo para foco de informação (28) e contrastivo ou exaustivo (29):

(28) a. O que o João comprou?

b. O João comprou um carro.

b'. [IP O João comprou [FocP um carro [vP $\ldots .]$.$] .$

(29) a. Um carro (que) o João comprou (e não um avião).

$a^{\prime}$. [FocP Um carro ( $_{\text {(que) }}$ [IP o João comprou $\left.\mathrm{t}_{\mathrm{i}}\right]^{2} .^{26}$

b. O que o João comprou foi um carro.

\footnotetext{
${ }^{25}$ Exemplos (8) de Mioto (2003), p. 174.

${ }^{26}$ Exemplo (27) de Mioto (2003), p. 186.
} 
b'. [IP O que o João comprou foi [FocP um carro [vP $\ldots .]].]^{27}$

Para sentenças com foco in situ que apresentam características semânticas contrastivas ou exaustivas, Mioto assume, a partir de Kayne (1994), que na derivação há pelo menos mais um movimento de IP remanescente para Spec de TopP. Como abaixo:

(30) a. O João comprou um carro (e não um avião).

b. [TopP [IP O João comprou $\left.t_{i}\right]_{k}\left[\right.$ FocP um carro $\left[\right.$ IIP $\left.\left.\left._{\mathrm{k}}\right]\right]\right] .^{28}$

Em (30), ocorre um movimento do constituinte focalizado para o Spec de FocP, em que posição original é marcada pelo vestígio $t_{i}$, e depois o ocorre o movimento de todo o IP para Spec de TopP. O vestígio $t_{k}$ marca a posição original de IP.

A justificativa do autor para o foco in situ com características contrastivas ou exaustivas se mover para a periferia esquerda da sentença e não para a periferia baixa é que, como em PB constituintes de focos deslocados para uma posição na periferia esquerda da sentença necessariamente possuem traços semânticos de contrastividade ou exaustividade, foco in situ com tais características deverão ocupar a mesma posição sintática. Do contrário, teríamos uma posição ambígua em Spec de FocP na periferia baixa, já que esta abriga constituintes de foco informacional.

Mioto(2003), por fim, conclui com seu trabalho que constituintes de foco sempre vão se deslocar para Spec da categoria FocP e esta categoria pode estar interna ao IP, no caso de focos de informação ou na periferia esquerda da sentença, quando os constituintes apresentarem traços semânticos contrastivos ou exaustivos. ${ }^{29}$

Na presente pesquisa, assumimos com o autor que em português brasileiro, focos não informacionais que possuem traços semânticos de contrastividade, exaustividade ou sobreinformatividade, que veremos mais adiante, movem-se para uma posição na periferia esquerda da sentença, diferentemente de focos meramente informacionais.

Com relação ao tipo de foco proposto neste trabalho, sobreinformativo, que

${ }^{27}$ Exemplos em (26) de Mioto (2003), p. 185.

${ }^{28}$ Exemplo (30) de Mioto (2003), p. 187.

${ }^{29}$ Há também, para o PB, o trabalho de Quarezemin (2009), que assume a proposta de Mioto para análise sintática de focos contrastivos e informacionais. Quarezemin constatou, a partir de experimentos em forma de questionário, que os elementos focalizados em PB podem ser destacados na sentença pela estrutura sintática aberta (PF) ou pela combinação da prosódica com uma posição sintática específica de foco em LF. Além disso, a autora também observou que as estratégias para focalizar o constituinte na posição de objeto diferem das estratégias de focalizar o constituinte na posição de sujeito. 
discutiremos com mais detalhes no próximo capítulo, assumimos com Mioto, que por ter um traço semântico distinto, deve se mover na estrutura sintática para a posição de Spec de FocP da periferia esquerda da sentença.

\subsection{SINTAXE E SEMÂNTICA DO FOCO SOBREINFORMATIVO}

Antes de olharmos para sentenças focalizadas que possam apresentar inversão de escopo, apresentamos um modelo de estrutura sintática que abrange a hierarquia para os sintagmas quantificados proposta por Beghelli \& Stowell (1997) e a cartografia da periferia esquerda de Rizzi (1997).

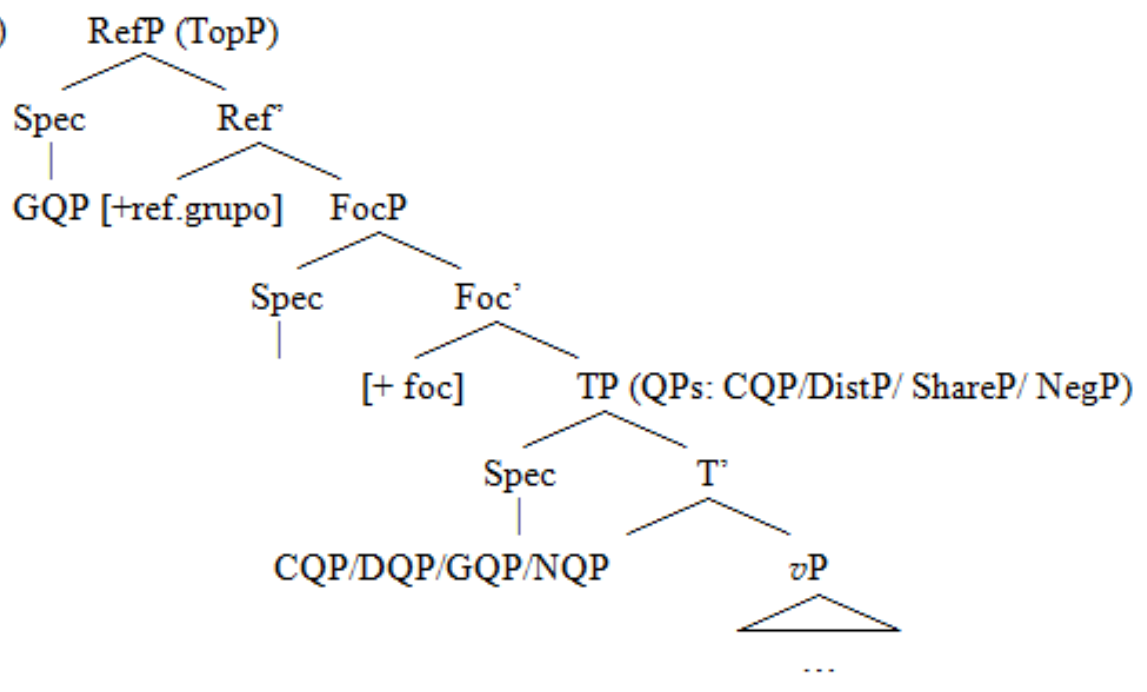

$\mathrm{Na}$ estrutura hierárquica acima, propomos que a categoria discursiva de FocP ccomanda as categorias de QP que estão localizadas, segundo a proposta de Beghelli \& Stowell dentro de TP. Por questão de espaço, apresentaremos apenas a categoria do quantificador presente na sentença, assim como seu traço pra checar. Para DistP, traço [+ dist]; NegP, traço [+neg], ShareP [+ヨ]. O único sintagma quantificado que ocupa uma posição fora do domínio de FocP é o GQP que possui um traço [+ referência de grupo] para checar. Tal sintagma ocupa a posição de Spec de RefP e c-comanda a categoria FocP. Essa posição também pode ser considerada por Spec de TopP. ${ }^{30}$

\footnotetext{
${ }^{30}$ Não é óbvio que sintagmas com traços [+ referência de grupo] ocupem a mesma posição sintática de TopP. Talvez, a categoria RefP esteja uma posição abaixo de TopP. No presente trabalho, entretanto, não nos aprofundaremos nestas questões, e assumiremos que RefP e TopP ocupam a mesma posição na estrutura
} 
A partir das teorias até aqui apresentadas e da proposta hierárquica de árvore sintática, vejamos quais as operações sintáticas e semânticas que ocorrem com sentenças que possuam dois sintagmas quantificacionais, como em (32), abaixo:

(32) Mais de dois alunos reclamaram de toda palestra do congresso ${ }^{31}$.

Quando enunciada em um contexto que podemos chamar de não marcado (ou seja, em que a pergunta em discussão seria algo como “o que aconteceu ontem?”), a leitura mais saliente, senão a única, para essa sentença é a de que o número de alunos que reclamaram de todas as palestras do congresso é maior que dois. A representação lógica dessa leitura está em (33) abaixo (ver Heim e Kratzer 1998 para a obtenção dessa representação através de um sistema interpretativo composicional):

(33) $\mid\{$ y: y é aluno $\} \cap\{$ y: $\forall \mathrm{x}: \mathrm{x}$ é palestra do congresso $\rightarrow[$ y reclamou de $\mathrm{x}]\} \mid>2^{32}$

Como se pode notar, o sintagma quantificado de contagem (CQP) "mais de dois" é interpretado como tendo escopo sobre o sintagma quantificado universal (DQP) "toda palestra do congresso", pois o primeiro se mantém em sua posição de caso, enquanto o último se move para a posição de Spec de DistP, abaixo do anterior. Essa ordem de escopo reflete a hierarquia sintática da estrutura aberta da sentença em que o sujeito c-comanda assimetricamente o objeto. Tal estrutura pode ser representada por (34): $:^{33}$

sintática e deixamos em aberto tal questão para trabalhos posteriores.

31 Atentando-se para a conclusão de Negrão (1999) de que quantificadores distributivos (DQPs) na posição de objeto sem um modificador é considerado agramatical no PB, as sentenças com DQPs na posição de objeto apresentadas foram elaboradas com modificadores.

${ }^{32}$ Adotaremos no presente trabalho este tipo de notação formal que se utiliza de lógica de predicados e relação de conjuntos.

${ }^{33} \mathrm{Na}$ proposta de B\&S, o CQP está em Spec, AgrSP, mas assumindo que não existem projeções Agr no Minimalismo (Chomsky 1995, capítulo 4), suponho que o CQP esteja alojado na posição de Spec,TP. 


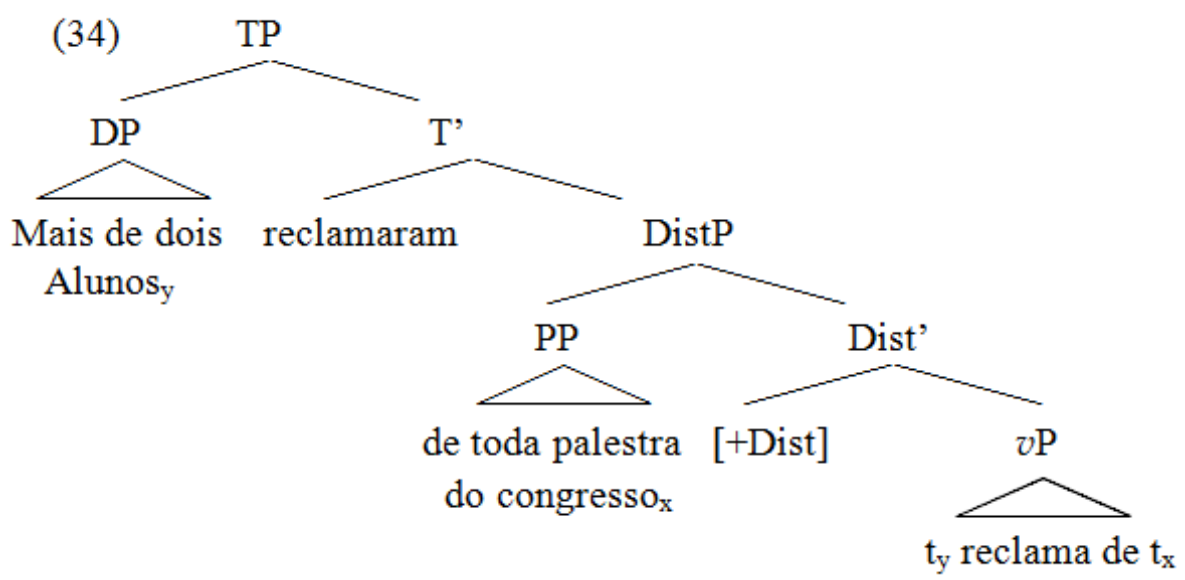

A estrutura acima, que é enviada pra PF (forma fonológica), representa a mesma que segue para LF (forma lógica), em que o quantificador na posição de sujeito ocupa a posição de especificador de TP na árvore, mais alta do que o quantificador na posição de objeto. Para o contexto dado anteriormente, essa estrutura é suficiente, sem necessidade dos constituintes se moverem para uma das categorias funcionais de CP apresentadas pela cartografia de Rizzi (1997).

Considere agora um contexto diferente: dois professores que participaram de um congresso estão conversando e um professor comenta com o outro: "Mais de dois alunos reclamaram da minha palestra". O outro, para consolá-lo, responde: "Não deve ser nada pessoal, porque mais de dois alunos reclamaram de TODA PALESTRA DO CONGRESSO". Aqui, a mesma sentença que vimos acima parece admitir uma outra interpretação, a saber, a de que para cada palestra $\mathrm{x}$, mais de dois alunos reclamaram de x. Em notação mais formal:

(35) $\forall \mathrm{x}: \mathrm{x}$ é palestra do congresso $\rightarrow \mid\{\mathrm{y}: \mathrm{y}$ é aluno $\} \cap\{\mathrm{y}:[\mathrm{y}$ reclamou de $\mathrm{x}]\} \mid>2$

Desta vez, é o sintagma quantificado na posição de objeto que tem escopo sobre o sintagma na posição de sujeito. Estamos diante de um caso de inversão de escopo, em que um constituinte que ocupa uma posição hierarquicamente inferior ao outro constituinte em PF é interpretado como tendo escopo sobre ele. A leitura representada por (35) pode ser parafraseada por: "para cada palestra do congresso houve uma quantidade de alunos, maior do que dois, que reclamou da palestra". Ou seja, os alunos que reclamaram das palestras não necessariamente foram os mesmos, diferentemente da leitura anterior.

Para a interpretação de escopo invertido, a estrutura sintática apresentada acima, em (34), não é compatível. Ao ser enviada para LF, ocorre pelo menos mais um movimento em 
que o DQP que está na posição de objeto passa a ter escopo sobre o CQP na posição de sujeito. Propomos duas opções de estrutura sintática pra tal leitura, a primeira que representa a estrutura em LF para a sentença (32) e outra, que segue a proposta de Mioto (2003), que por sua vez adota Kayne (1994), em que todo o TP se move para Spec de TopP.

(36)

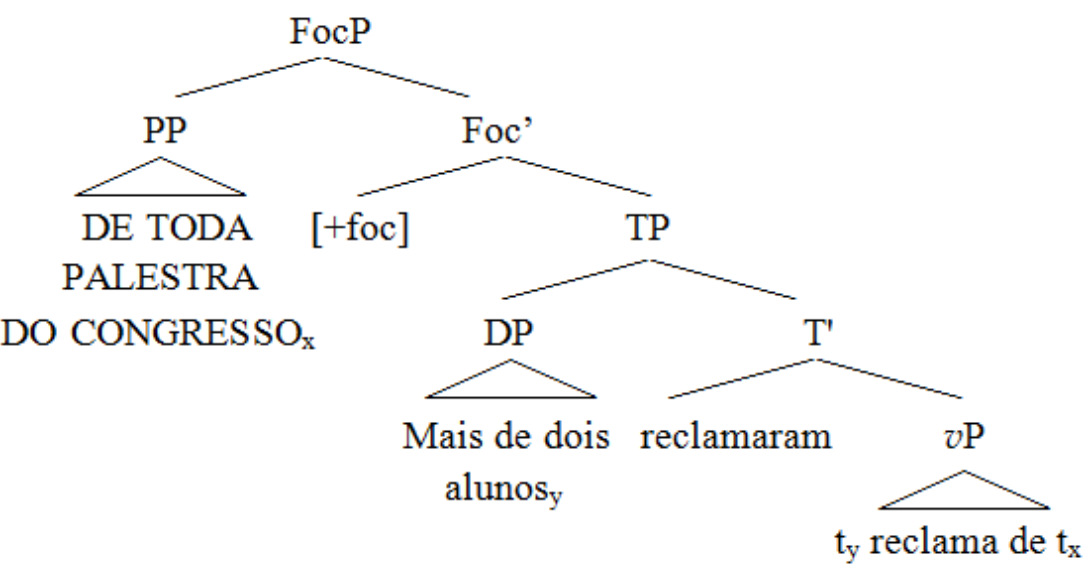

$\mathrm{Na}$ estrutura em (36), até a categoria funcional TP, as operações que ocorrem são as mesmas da estrutura anterior. A diferença, entretanto, é que o constituinte "toda palestra do congresso" entra na derivação com um traço discursivo de foco, que não pode ser checado em TP. Este constituinte, então, tem de ser movido para Spec de FocP, para ter seu traço [+foc] checado. Dessa forma, temos em LF, a representação da interpretação de escopo invertido, a partir do contexto dado acima para a sentença (32).

A estrutura abaixo representa a segunda opção e segue Kayne (1994) e Mioto (2003):

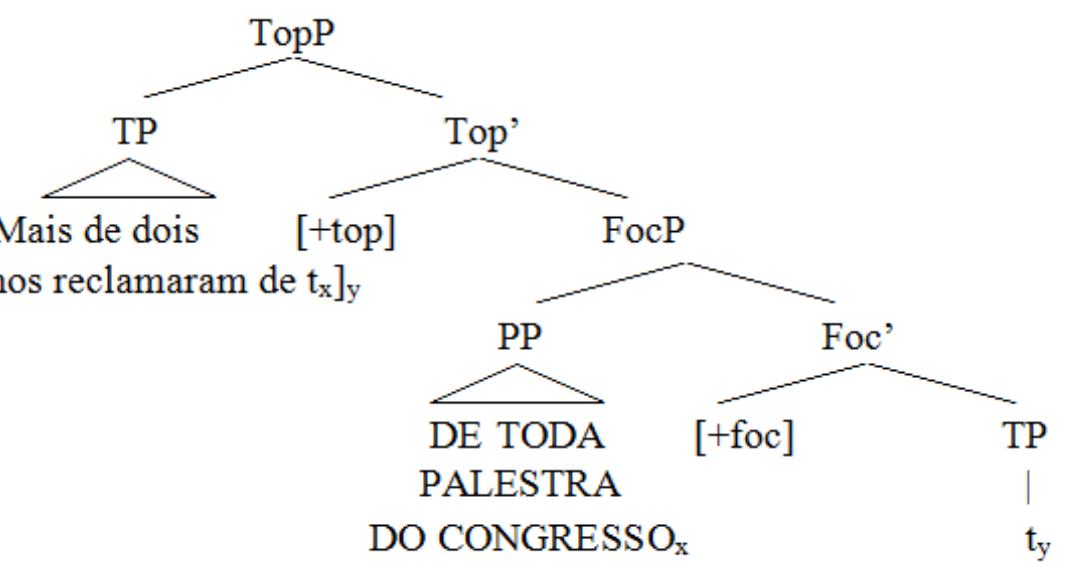

Na estrutura dada em (37), primeiramente, o PP, que tem um traço semântico de foco, move-se para a posição de Spec de FocP da periferia esquerda de sentença, deixando um 
vestígio $t_{2}$. Em seguida, todo o TP se move para a posição de Spec de TopP. Esta estrutura mantém a sintaxe visível da sentença. Vejamos, porém, se sua composição semântica corresponde à leitura de escopo inverso, dada em (35). Para a derivação semântica, assumimos a proposta de Heim \& Kratzer (1998), em que na árvore sintática, o índice numérico do constituinte movido é transferido para um constituinte irmão deste. Vejamos, passo a passo, como segue tal derivação.

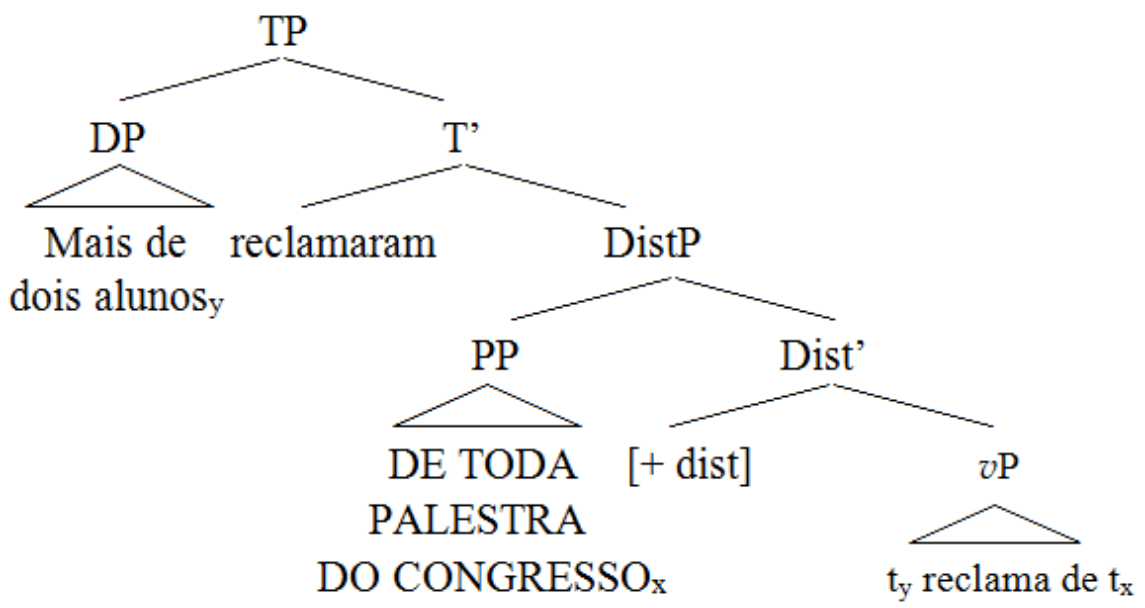

Em (38), ilustramos os movimentos ocorridos no domínio de TP. O sintagma quantificado na posição de sujeito move-se para sua posição de caso, em Spec de TP. Já o sintagma na posição de objeto, por ter um traço mais distributivo pra checar, move-se para sua posição de Spec de DistP, dentro de TP. Entretanto, esse sintagma ainda tem um traço de foco a ser checado. Deve, portanto, mover-se para a periferia esquerda da sentença. Este segundo passo é ilustrado abaixo.

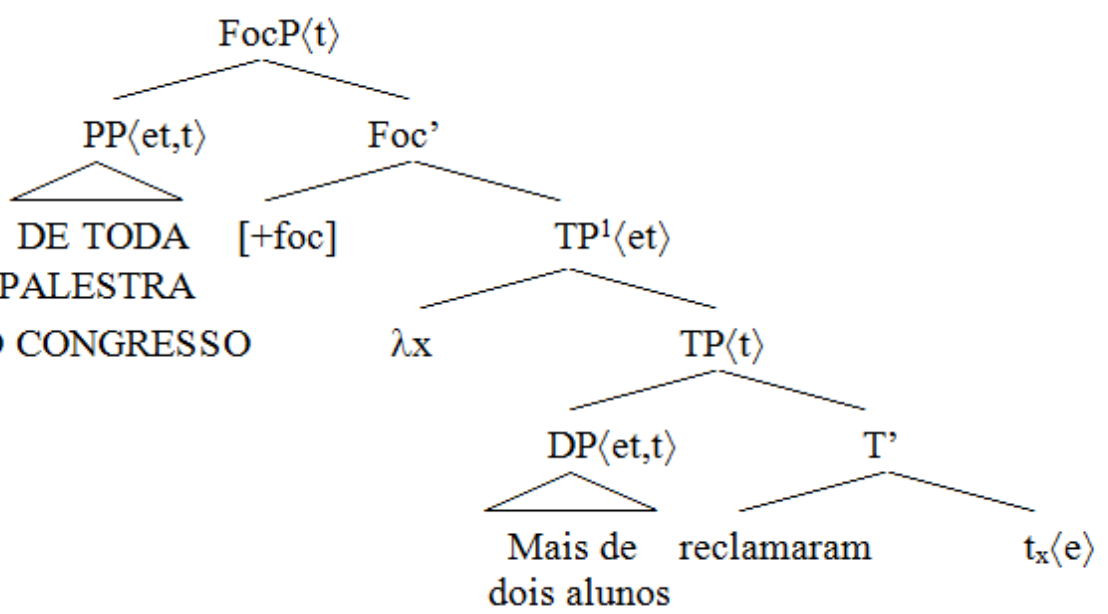


$\mathrm{Na}$ estrutura sintática acima, apresentamos os movimentos ocorridos dentro de FocP. O PP "DE TODA PALESTRA DO CONGRESSO", que tinha um traço de foco ainda para checar, move-se para a posição de Spec de FocP, deixando um vestígio "x" do tipo semântico $\langle\mathrm{e}\rangle$. O índice numérico do QP movido é transferido na árvore para um constituinte irmão, representado por " $\lambda \mathrm{x}$ " (Rotulamos a categoria que abriga tal constituinte de $\mathrm{TP}^{1}$ ). Falta, ainda, que o TP se mova para a posição de Spec de TopP. Este movimento é representado a seguir:

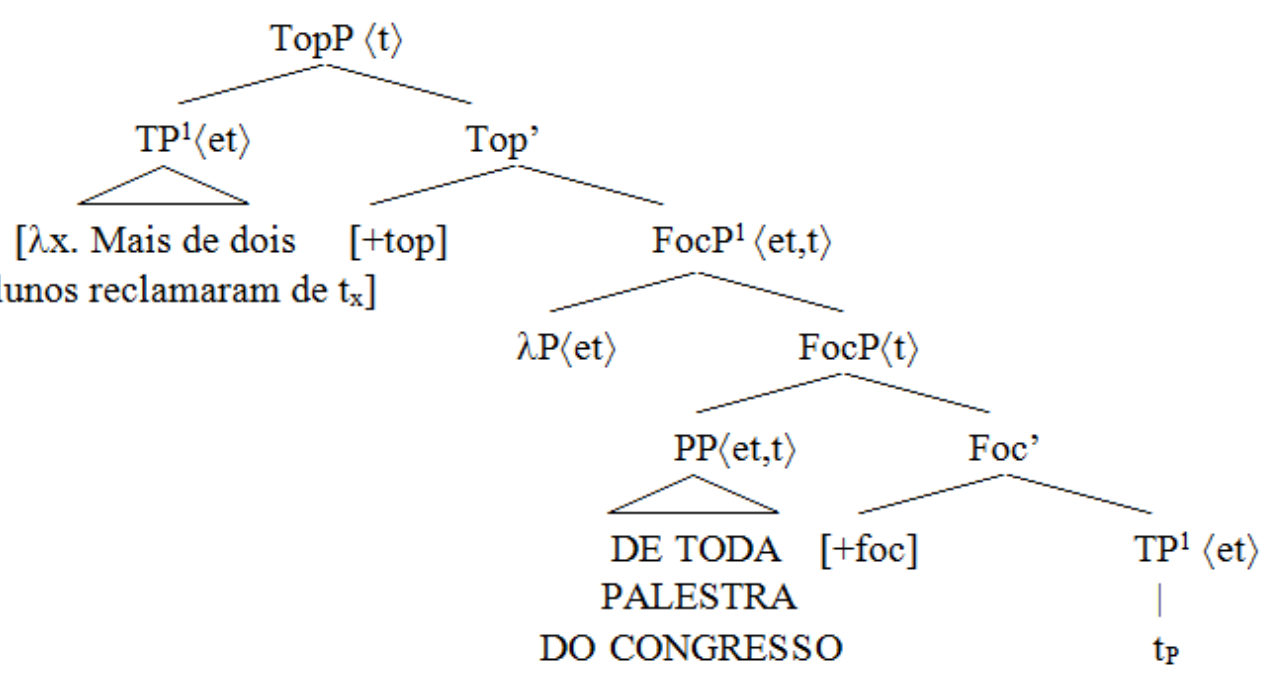

Na estrutura acima, $\mathrm{TP}^{1}$ se move para Spec de TopP e deixa um vestígio $\mathrm{P}$, do tipo $\langle$ et $\rangle$, uma propriedade. O PP [[de toda palestra do congresso]], do tipo $\langle$ et, $t\rangle$, toma $\mathrm{TP}^{1}$ como argumento e retorna a uma proposição como: $\forall \mathrm{x}: \mathrm{x}$ é palestra do congresso $\rightarrow \mathrm{P}(\mathrm{x})=1$. Assumindo o tipo representativo de Heim \& Kratzer (1998), então, a partir de abstração funcional, temos a propriedade: $\lambda \mathrm{P} . \forall \mathrm{x}: \mathrm{x}$ é palestra do congresso $\rightarrow \mathrm{P}(\mathrm{x})=1$. A partir de aplicação funcional, tal propriedade toma $\mathrm{TP}^{1}$ como argumento e retorna a seguinte proposição: $\forall \mathrm{x}: \mathrm{x}$ é palestra do congresso $\rightarrow \mid\{\mathrm{y}: \mathrm{y}$ é aluno $\} \cap\{\mathrm{y}:[\mathrm{y}$ reclamou de $\mathrm{x}]\} \mid>2$. Exatamente a apresentada em (35).

A segunda opção de estrutura sintática parece ser mais interessante, visto que não alteramos a ordem da sintaxe visível, porém obtivemos a composição semântica desejada, com a interpretação de escopo invertido. Além disso, nessa estrutura fica claro que o elemento que recebe a função de tópico é a propriedade de " $\lambda \mathrm{x}$. Mais de dois alunos reclamaram de $\mathrm{x}$ ', e não apenas o DP “mais de dois alunos". No contexto dado, é exatamente a propriedade que está em jogo. Reformularemos a estrutura dada em (31), então, para a seguinte: 
$(41)$

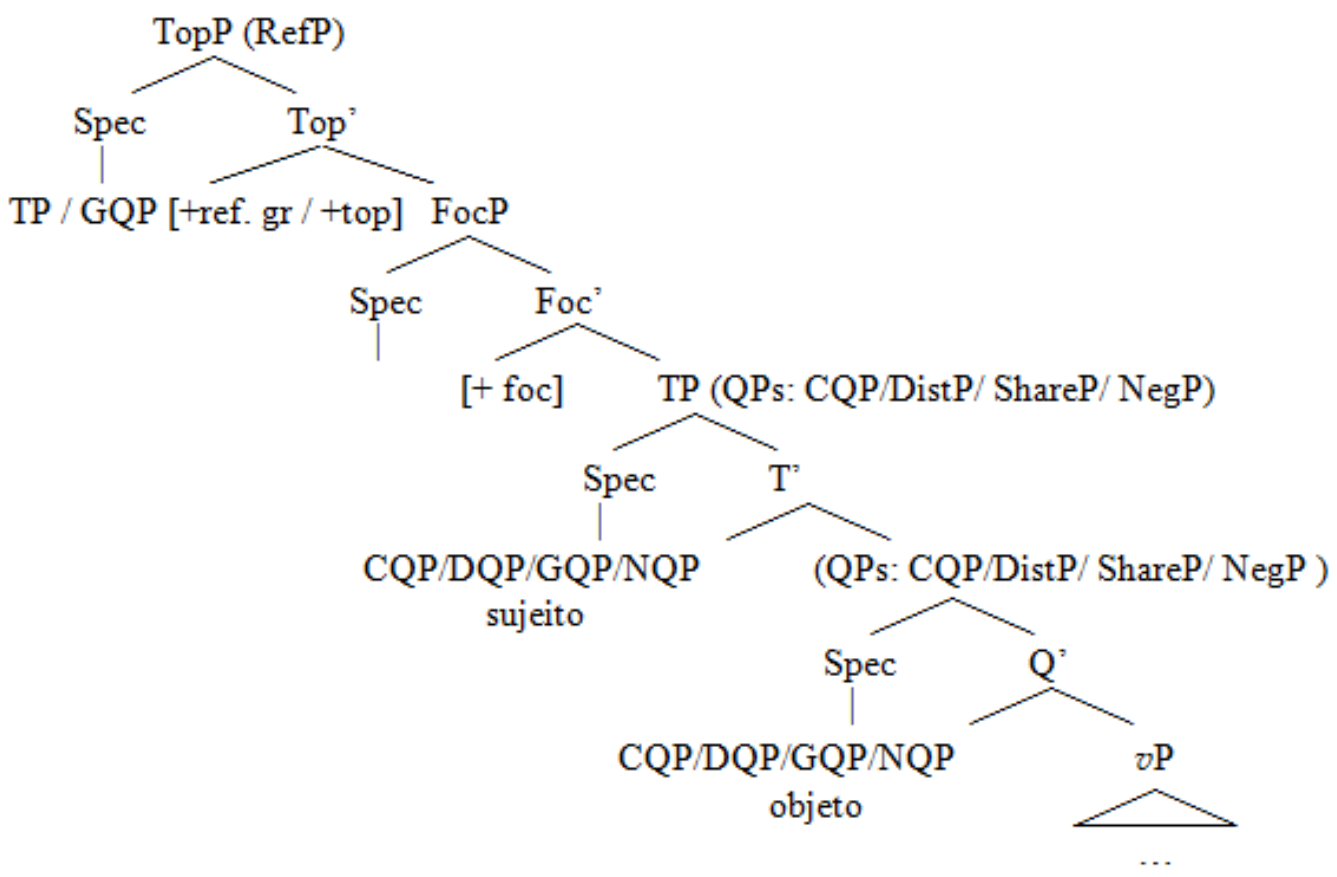

$\mathrm{Na}$ estrutura acima, acrescentamos a categoria TopP acima de FocP. Esta categoria, que também pode ser rotulada de RefP, pode ser preenchida por: i) GQPs que apresentem um traço [+referência de grupo], que indica que tais QPs são quantificadores que especificam um grupo, (segundo a proposta de Beghelli \& Stowell (1997), estes QPs se movem para uma posição acima de $\mathrm{CP}$ ); ii) um TP que tenha um traço discursivo de tópico. Sintagmas quantificados dos tipos CQP, DQP, NQP ou GQP apenas com traço [+ existencial] mantêm-se dentro de TP, como já havíamos proposto na estrutura em (31). Constituintes GQP com traço [+ referência de grupo], então, se movem para uma categoria de Spec de RefP ou TopP, para checar seu traço. A partir de agora, adotaremos a estrutura em (41) para todos os exemplos de sentenças marcadas por traços discursivos (veremos, mais adiante no capítulo 3, sentenças com outros tipos de sintagmas quantificados).

Voltando para a sentença (32), o que foi crucial para a obtenção da interpretação de escopo invertido, foi a entonação peculiar (representada pelas letras maiúsculas acima) com que o sintagma objeto foi pronunciado. Essa entonação indica que o falante está abordando uma pergunta (implícita) do tipo "de que palestras mais de dois alunos reclamaram?" Com isso, o sintagma quantificador objeto aparece focalizado na resposta, o que parece ser o motivo pelo qual a interpretação de escopo invertido se tornou saliente.

É importante ressaltar que parece não ser qualquer tipo de contexto que permita a inversão de escopo. No contexto dado, temos uma situação de sobreinformatividade, em que o 
constituinte focalizado não apresenta uma função de foco informacional, já que o constituinte "de toda palestra do congresso" é contrastado com "da minha palestra", em relação à propriedade de "mais de dois alunos reclamarem". Na verdade, o falante, não nega que o constituinte "minha palestra" seja alvo da reclamação dos alunos, mas em uma tentativa de amenizar a situação, quer deixar claro que a propriedade de receber reclamação não é exclusiva da palestra do professor em questão, mas de todas as palestras do congresso.

Ressaltamos que esse tipo de foco não se enquadra no conceito de foco contrastivo dado por Zubizarreta (1998) que Mioto (2003) adota. Segundo tal conceito, o constituinte focalizado deve negar o constituinte dado pelo contexto e descartá-lo. No caso do contexto dado acima, a marcação de foco não indica que o elemento focalizado elimina o elemento dado pelo contexto, mas que o primeiro inclui o último. A contrastividade se dá a partir da negação de exaustividade da propriedade em relação ao elemento dado. Por este motivo não adotaremos o conceito de foco contrastivo de Zubizarreta e sim um tipo diferente de foco, que denominamos foco sobreinformativo. Assumiremos, porém, conforme Mioto defende, que a marcação de foco em sentenças como a acima, por serem diferentes de focos meramente informacionais, movem-se para uma posição na periferia esquerda da sentença, acima de TP.

Para melhor entendimento dos fenômenos semânticos e pragmáticos ocorridos nas sentenças em estudo, assim como conceitos de perguntas explícitas e implícitas, que serão cruciais para o entendimento de tais fenômenos, o capítulo a seguir está reservado para apresentação de algumas propostas pragmáticas e semântico-pragmáticas e para a discussão do foco sobreinformativo, apresentado no contexto acima.

\subsection{RESUMO DO CAPÍTULO}

Neste capítulo propomos uma estrutura sintática para sentenças do português brasileiro com foco não informacional que mantém a ordem da sintaxe aberta, além de dar conta da composição semântica correspondente à leitura de escopo inverso. Além disso, identificamos um outro tipo de foco não abordado pelos pesquisadores que investigaram este tema, o foco sobreinformativo. Tal foco ocorre em contextos em que não necessariamente o elemento dado no discurso é negado, mas a não exaustividade da propriedade em discussão. Também, foram brevemente apresentadas as teorias que servem de background para esse estudo. Em relação às teorias de quantificação e escopo, destacamos a proposta de Beghelli \& Stowell (1997), na qual as relações de escopo não ocorrem de maneira uniforme com todos os 
sintagmas quantificados. Em relação ao português brasileiro, apresentamos a proposta de Negrão (1999), que se baseia em Beghelli \& Stowell para defender que tal língua apresenta uma sintaxe mais rígida no que diz respeito à relação de escopo e, sentenças em contextos neutros, dificilmente apresentam inversão de escopo. Ainda, apresentamos as propostas de Cartografia, de Rizzi (1997), para a estrutura sintática de sentenças focalizadas e destacamos o trabalho de Mioto (2003), que defende que em PB um constituinte de foco contrastivo ocupa a posição de Spec de FocP da periferia esquerda da sentença, enquanto constituintes de focos puramente informacionais ocupam uma posição mais baixa, Spec de FocP de vP (cf. Belletti (2004)).

A partir desta base teórica, analisamos uma sentença com dois sintagmas quantificados, um na posição de sujeito e outro na posição de objeto, e observamos que em contextos neutros a leitura mais saliente, senão a única, é a de escopo linear. Sua estrutura sintática em LF é idêntica à estrutura da sintaxe aberta. No entanto, se houver um contexto específico, em que a pergunta implícita ou explícita seja mais restrita e o sintagma quantificado na posição de objeto receba uma marca de foco peculiar, é possível ocorrer leitura de escopo invertido. Este sintagma, então, se move para uma posição mais alta que o sintagma na posição de sujeito, em Spec de FocP na periferia esquerda da sentença, de acordo com Rizzi(1997) e Mioto(2003). Para tal leitura, apresentamos duas propostas de estrutura sintática, uma de LF, e outra que mantém a mesma ordem da sintaxe visível, porém dá conta das derivações semânticas para uma interpretação de escopo inverso.

No contexto de inversão de escopo, entretanto, há uma particularidade pragmática, em que o falante tenta amenizar uma situação negativa demonstrando que a propriedade apresentada "mais de dois alunos reclamarem de x" não é exclusividade do elemento em questão, mas sim de todos os elementos do conjunto ao qual ele faz parte. Parece que o falante responde implicitamente a uma pergunta além do que está sendo discutido no contexto.

Fenômenos pragmáticos como perguntas implícitas e explícitas, respostas completas e parciais, assim como contextos apresentados para a sentença acima, em (32) serão discutidos a seguir, no próximo capítulo, visto que tais conceitos serão essenciais para identificarmos o que ocorre com sentenças como o exemplo apresentado neste capítulo, em que há possibilidade de inversão de escopo em PB. Depois de identificarmos qual a influência pragmática para obtenção de tais leituras, retornaremos, no capítulo 3 , com a observação do fenômeno de foco sobreinformativo e inversão de escopo em PB, e então, testaremos sentenças com outros tipos de quantificadores como GQPs existenciais (alguns alunos), GQPs 
cardinais (dois alunos) e DQPs (todo aluno). 
CAPÍTULO 2

Foco Sobreinformativo e ESTRATÉgias de RESPOSTA

\subsection{INTRODUÇÃO}

Este capítulo tem como objetivo identificar as restrições pragmáticas ocorridas em contextos apresentados no capítulo anterior. No contexto criado, parece que a inversão de escopo foi possível em virtude de uma peculiaridade pragmática, em que a não-exaustividade do elemento dado foi contrastada com o conjunto total de elementos ao que o primeiro faz parte. Repetimos a sentença analisada no capítulo 1 abaixo.

(1) Mais de dois alunos reclamaram de toda palestra do congresso.

Imaginemos que dois professores estão conversando sobre determinado congresso de que ambos participaram. A conversa é descrita abaixo:

(2) Professor A: Estou chateado: Mais de dois alunos reclamaram da minha palestra.

Professor B: Não se preocupe, não é nada pessoal: Mais de dois alunos reclamaram de TODA PALESTRA DO CONGRESSO.

No contexto acima, o professor B, ao ouvir a fala de seu colega, parece tentar minimizar o problema, quando enfatiza que a propriedade "Mais de dois alunos reclamarem" não diz respeito exclusivamente à palestra proferida pelo professor $\mathrm{A}$ e sim que cada uma das palestras do congresso tem esta propriedade. O professor contrasta a informação dada com uma sobreinformação. Na verdade, o contraste se dá porque o falante quer deixar claro que a propriedade em discussão "ter sido alvo da reclamação de mais de dois alunos ( $\lambda$ x. mais de dois alunos reclamaram de x)" não é exaustiva em relação ao elemento dado, "palestra do professor A", mas faz parte de um conjunto todo, no caso, o conjunto de palestras do congresso. Com isso, o falante dá informações além das requeridas. É como se ficasse implícito algo do tipo: "A propriedade de Mais de dois alunos reclamarem não é só sua", antes do professor B declarar o que está em (2). Ao dar essa resposta, o professor faz uso de uma estratégia que parece ser bastante utilizada pelos falantes em geral. Veja o exemplo 
abaixo, em (3):

(3) A: O João foi pra festa?

B: \TODO MUNDO foi pra festa.

A conversa acima pode ser empregada em um contexto em que houve uma festa e o falante A quer saber se o João foi. O falante B, pra deixar claro que a propriedade de ir pra festa não é exclusiva do João, mas de todos os indivíduos salientes no contexto, responde que "Todo mundo foi pra festa". Tal afirmação acarreta que João foi pra festa, mas também traz informações sobre todos os demais convidados.

A este tipo de fenômeno da língua, que ocorre nas sentenças (1) e (3), chamaremos de respostas sobreinformativas. Neste capítulo observaremos, a partir de teorias pragmáticas e semântico-pragmáticas, quais restrições de contexto ocorrem em sentenças como a apresentada acima, em (3), e depois faremos uma comparação com sentenças como a apresentada no capítulo 1 (e repetida aqui, em (1)) para identificar se tais restrições pragmáticas contribuem para leituras de inversão de escopo.

Para isso, apresentaremos a teoria de Grice (1967) sobre O Princípio de Cooperação, bem como suas máximas conversacionais e o conceito de implicaturas conversacionais. Logo após, discutiremos a proposta de Roberts (1996), que defende que todo discurso está direcionado para responder perguntas, sejam elas implícitas ou explícitas. Após, faremos uma breve discussão sobre as propostas de Büring (1999) e (2003), na qual o autor apresenta alguns tipos de construções em que o falante não responde exatamente ao que é requerido, mas parcialmente, ao que ele chama de tópico parcial, ou muda a direção da conversa com sua resposta, tópico contrastivo. A partir destes pressupostos teóricos, olharemos para sentenças que contenham quantificadores universais como "todo" e negativos como "ninguém" e "nada" nas posições de argumento interno e externo e em contexto de perguntas polares, perguntas de constituintes nas posições de sujeito, objeto, locativo ou dativo. E então, por fim, retornaremos às sentenças as quais esta pesquisa se propõe a investigar, a fim de identificar se restrições pragmáticas influenciam na interpretação de inversão de escopo para tais sentenças. 


\subsection{AS MÁXIMAS CONVERSACIONAIS: GRICE (1975)}

Em seu artigo de 1975, Grice apresenta O Princípio de Cooperação, o qual ele defende estar presente em praticamente todas as conversações que tenham como propósito trocar informações. O princípio de cooperação consiste na ideia de que o falante direta ou indiretamente tem pretensões de cooperar com o bom andamento da conversa da qual é participante. Este princípio está baseado no que Grice chama de quatro máximas conversacionais. A primeira, a máxima de qualidade, consiste no pressuposto de que o falante cooperativo diz apenas o que acredita ser verdade, não declara informações que acredita serem falsas, nem para as quais não tem evidências suficientes que comprovem sua autenticidade. A máxima de quantidade prediz que o falante geralmente traz à conversação exatamente as informações exigidas. Esta máxima é dividida em duas submáximas. A primeira afirma que o falante não deve omitir informações de que tenha conhecimento e a segunda que o falante não deve dar informações além do necessário. Outra máxima, a de relevância, declara que só é dito aquilo que para o falante é definitivamente importante para o tópico da conversação. A última, de modo, prediz que o falante deve ser claro em sua exposição, deve evitar a obscuridade e a ambiguidade, ser breve e ordenado.

As máximas conversacionais, segundo Grice, são respeitadas em qualquer conversação em que os falantes pretendem compartilhar informações. No entanto, há contextos em que estas parecem ser, num nível superficial, desrespeitadas.

(4) A: Você acha a Maria bonita?

B: Bom, ela se veste bem.

$\mathrm{Na}$ conversa em (4), à primeira vista, o falante em $\mathrm{B}$ não foi cooperativo com $\mathrm{A}$, não respondendo exatamente ao questionado. Parece que ele desrespeitou o princípio de cooperação, em especial a máxima de relevância, que prediz que o falante deve dar apenas informações que sejam relevantes para o tópico da conversação. Contudo, há informações implícitas nesta declaração que o falante A, envolvido em determinando contexto, é capaz de interpretá-las. Imaginemos que João seja o falante A e gosta da Maria. Pedro, o falante B, a acha feia. Quando João pergunta a Pedro sobre a beleza de Maria, o último para ser mais educado e não magoar o amigo, responde B. Esta resposta implica que o Pedro não acha a Maria bonita, no entanto, em nenhum momento Pedro disse isto explicitamente. Portanto, Pedro não deixou de ser cooperativo, e, em certa instância, respondeu ao que lhe foi 
perguntado, mesmo que não diretamente.

Informações implícitas, que não são pronunciadas pelo falante, mas que podem ser recuperadas a partir do contexto, são denominadas por Grice de implicaturas conversacionais. Essas implicaturas são inferências pragmáticas que possuem pelo menos quatro propriedades: são anuláveis: podem ser canceladas a qualquer momento; não-destacáveis: o enunciado original pode ser substituído por outro sinônimo ou semelhante e ainda assim a implicatura se mantém; calculáveis: é possível calcular a inferência presumida para dar conta do principio cooperativo na conversação; e são não-convencionais: exigem contextos específicos para serem interpretadas. Voltando ao nosso exemplo em (4), a implicatura gerada não é convencional, pois há necessidade de se conhecer o contexto para identificá-la. É calculável, pois, a partir dela, é possível obter a resposta requerida por A. É não-destacável. Se a propriedade "vestir-se bem" for substituída por uma expressão semelhante como "ela só usa roupa de marca", a implicatura de que Maria é feia se mantém. Poderia também ser cancelada da seguinte maneira:

(5) A: Você acha a Maria bonita?

B: Bom, ela se veste bem e é bonita.

Em (5), a implicatura de que Maria é feia é cancelada com a afirmação de B de que ela é bonita. As quatro propriedades das implicaturas conversacionais puderam ser verificadas em nosso exemplo. Além disso, podemos perceber, que num nível mais profundo de interpretação todas as máximas conversacionais, sobretudo a de relevância, foram respeitadas.

Os casos específicos de estudo deste capítulo, como o exemplo abaixo, em (6), mesmo que superficialmente pareçam infringir algumas máximas conversacionais, na verdade, num nível mais profundo de interpretação, respeitam a todas elas.

(6) A: O João foi pra festa?

B: TODO MUNDO foi pra festa.

Em (6), parece que o falante $B$ violou a segunda sub-máxima de quantidade que prediz que um falante cooperativo não dá informações além do necessário. No entanto ao dar tal resposta, que denominamos de resposta sobreinformativa, o falante responde ao que foi requerido, pois quando diz que "Todo mundo foi pra festa", se João é integrante deste conjunto, de certa maneira responde ao questionado. Tal atitude demonstra que o falante está 
cumprindo outra máxima, a da relevância, pois ao dar a resposta sobreinformativa, B acredita que seja mais relevante dar informações sobre todos os elementos do conjunto a que "João" faz parte. Contextos como (6), em que o falante se utiliza de uma resposta sobreinformativa, serão mais bem observados mais adiante, neste capítulo.

Nesta seção foi apresentada a teoria de Grice do Princípio de Cooperação e suas máximas da conversação. Também foi discutido como, em geral, tal Principio é cumprido, assim como suas máximas, mesmo que em um nível mais profundo de interpretação. Essas interpretações, que não se encontram no nível superficial, são chamadas de implicaturas conversacionais e serão observadas nas construções que são objeto de estudo deste capítulo, ou seja, as respostas sobreinformativas. Além da teoria de Grice, veremos nas próximas seções um pouco das propostas de Roberts (1996) e Büring (1999) e (2003), que a partir da teoria de Grice, exploram alguns fenômenos da língua relacionados às máximas conversacionais e à estrutura da informação e, então propõem formalizações para estes.

\subsection{ESTRATÉGIAS DE PERGUNTAS E RESPOSTAS: ROBERTS (1996)}

Buscando aprofundar os estudos sobre a Estrutura da Informação, Roberts (1996) explora tal tema não apenas pelo enunciado dado pelo discurso, mas sim pelo que está por trás deste: o que motivou e o que levou o falante a proferir determinada sentença. Para tanto, a autora faz uma comparação entre a conversação e a teoria dos jogos. Assim como em um jogo, um discurso possui: participantes, objetivos, estratégias, regras e movimentos para alcançar tais objetivos.

Em um discurso em que os participantes possuem como objetivo comum compartilhar informações sobre o mundo, estes buscarão contribuir para o bom andamento da conversação. Segundo Stalnaker (1978), este objetivo está voltado para responder à "grande questão" (big question): “Como as coisas são?” (What is the way things are?). No entanto, em uma conversa não é possível responder completamente a tal questão. Então, os falantes se utilizam da estratégia de responder a sub-questões relacionadas a esta. Roberts assume com Carlson (1983) que todo discurso é organizado em relação a perguntas e respostas, sejam elas implícitas ou explícitas. Os participantes da conversa, primeiramente aceitam a questão mais imediata que está em discussão, que Roberts chama de questão sob discussão (QUD), e tendem a buscar uma resposta pra ela. Respondendo à questão sob discussão, o falante responde parcialmente à grande questão. 
Alguns elementos compõem o jogo do discurso e são imprescindíveis para atingir o objetivo: i) o common ground (cf. Stalnaker (1978)), que representa o conjunto de proposições que os participantes do discurso compartilham e a tomam como verdadeiras; ii) dois tipos de regras, as convencionais, como a sintaxe e a composição semântica da língua e as conversacionais, como as máximas de Grice; iii) movimentos setup e payoff, o primeiro representa o uso das questões no discurso e o segundo, uso de asserções, respostas para a questão sob discussão. ${ }^{34}$

Para formalização de questões, interessa-nos os conceitos Q-alternative set, de Hamblin (1973), e de respostas parciais e completas Groenendijk \& Stokhof (1984). Ambos são assumidos Roberts como base teórica para a semântica das perguntas. Para Hamblin, uma questão denota um conjunto de proposições. Observe a seguinte questão:

(7) O que o João comprou?

A pergunta acima tem seu significado semântico formado por um conjunto de proposições possíveis para respondê-la. Suponhamos que no contexto, há três alternativas possíveis de objetos que João possa comprar: livros, roupas e calçados. Q-alternative set da questão em (7) será o conjunto de proposições: \{o João comprou livros, o João comprou roupas, o João comprou calçados\}. A denotação formal de (7), então, é a seguinte:

(8) [[O que o João comprou?] $]=\{$ o João comprou livros, o João comprou roupas, o João comprou calçados\}

Os participantes do discurso, ao ouvirem a questão e aceitá-la, buscam, dentro das alternativas acima, uma resposta adequada para ela. Groenendijk \& Stokhof definem dois tipos de respostas possíveis: completa ou parcial. Uma resposta parcial para determinada questão é uma proposição que contextualmente envolve avaliação de verdadeiro ou falso para pelo menos um elemento do conjunto de alternativas dessa questão. Uma resposta completa, por sua vez, é uma proposição que contextualmente envolve uma avaliação para cada elemento do conjunto de alternativas. Vejamos o exemplo abaixo:

\footnotetext{
34 A questão sob discussão faz uma partição no context set em mundos em que cada asserção das alternativas de resposta é verdadeira. Se a asserção é aceita, o context set diminui.
} 
(9) O que os alunos compraram?

Imaginemos que temos no contexto dois indivíduos: João e Pedro. Estes fazem parte do conjunto de alunos dado pela questão (9). Consideremos, também, duas possibilidades de compra para tais indivíduos: livros e roupas. Neste contexto, a denotação semântica para (9) é dada a seguir:

(10) $[[\mathrm{O}$ que os alunos compraram?]] $=\{$ João e Pedro compraram livros, João e Pedro compraram roupas, João comprou livros e Pedro comprou roupas, João comprou roupas e Pedro comprou livros\}

Se o falante responde com uma das proposições do conjunto de alternativas dado acima, como, por exemplo, em (11) abaixo, ele dá uma resposta parcial à questão (9). Se a resposta for (12), temos uma resposta completa para tal questão.

(11) O João comprou livros.

(12) Os alunos compraram livros.

A resposta (11), segundo a teoria de Groenendijk \& Stokhof, é uma resposta parcial para (9), porque avalia como verdadeira ou falsa ao menos uma das proposições de (10). No caso, as proposições "João e Pedro compraram roupas" e "João comprou roupas e Pedro comprou livros" são avaliadas como falsa, ficando as demais sem avaliação. (12), por sua vez, representa uma resposta completa para (9) porque avalia todas as proposições de (10). É verdadeira a proposição em que ambos os indivíduos compraram livros e falsas as demais.

Com essas noções de resposta completa e parcial, os autores definem o conceito de acarretamento de questões:

(13) Uma questão $q_{1}$ acarreta $q_{2}$ sse a resposta de $q 1$ produz uma resposta completa para $q_{2}$ (cf. Groenendijk \& Stokhof 1984:16).

Retomando aos exemplos dados anteriormente em (7) e (9), podemos observar uma relação de acarretamento entre essas duas questões. Repetimos as questões abaixo. 
(14) O que os alunos compraram?

(15) O que o João comprou?

Nos exemplos acima, a questão (14) acarreta (15), pois se (14) for respondida completamente, (15) será respondida, já que o conjunto de alternativas de (15) está contido conjunto de alternativas de (14), como vimos anteriormente. Se apenas a questão (15) obtiver uma resposta, como por exemplo: "O João comprou livros", teremos uma resposta parcial para (14).

Roberts afirma que a semântica para as questões é estática e, segundo a autora, é necessária uma visão mais dinâmica das questões e da estrutura da informação para compreender a estrutura do discurso. Desta maneira, a autora apresenta uma teoria formal para a estrutura de informação.

Estrutura informacional é, dentro desta proposta, um conjunto de movimentos no discurso subdividido em: (i) um conjunto de questões, implícitas ou explícitas, sendo que cada questão representa um conjunto de proposições; (ii) um conjunto de asserções ou respostas, em que cada asserção representa um conjunto de mundos possíveis; (iii) um conjunto de movimentos aceitos, sendo questões ou respostas. Estes conjuntos apresentam várias funções e relações entre si, sendo que os movimentos ocorrem no discurso de forma linear. Cada movimento aceito no discurso passa a fazer parte do common ground. O conjunto de questões sob discussão (QUD) representa as questões disponíveis para a o discurso. Tal conjunto é denominado metaforicamente de questões sob a pilha. Esta pilha de questões é ordenada, de maneira que as questões anteriores acarretem as mais ao topo da pilha. Então uma resposta completa para uma questão mais ao topo da pilha acarreta uma resposta parcial para uma questão anterior, como no exemplo abaixo:

(16) O que os alunos compraram?

a. O que o João comprou?

$\mathrm{a}_{1}$. O João comprou livros?

Resposta $\left(a_{1}\right): \operatorname{Sim}$.

$\mathrm{a}_{2}$. O João comprou roupas?

Resposta $\left(a_{2}\right)$ : Sim.

b. O que a Maria comprou?.

$\mathrm{b}_{1}$. A Maria comprou livros?

Resposta ( $\left.b_{1}\right)$ : Não. 


\section{$\mathrm{b}_{2}$. A Maria comprou roupas?}

Resposta $\left(b_{2}\right)$ : Sim.

No exemplo acima, a questão (16) acarreta: $a, a_{1}, a_{2}, b, b_{1}, b_{2}$ e suas respectivas respostas. A questão $a$, por sua vez, acarreta $a_{1}, a_{2}$ e suas respostas e $b, b_{1}, b_{2}$ e suas respostas. Se o falante responde $b_{1}$, por exemplo, dá uma resposta parcial à $b$ e, consequentemente à (16).

No que diz respeito à pragmática da asserção, se uma asserção é aceita pelos interlocutores em um discurso, ela é adicionada ao common ground em dado ponto do discurso. Quanto à pragmática de uma questão, se esta é aceita pelos interlocutores em um discurso, então ela é adicionada ao conjunto de questões sob discussão. Um membro do conjunto de questões sob discussão é removido de tal conjunto se ele é ou respondido ou identificado como não respondível. Adicionar uma questão na pilha de QUD acarreta um forte comprometimento em respondê-la. Se os interlocutores aceitam uma questão, essa permanecerá na pilha até ser respondida. Quando uma questão é respondida, é removida da pilha juntamente com qualquer questão que ela acarrete.

Com base no conceito de questão sob discussão (QUD), Roberts define que relevância está diretamente relacionada à QUD. Será relevante para o discurso uma resposta, seja ela parcial ou completa, para a questão sob discussão (QUD) ou uma questão relacionada a ela.

Após formalizar a estrutura da informação, Roberts discute o papel do foco prosódico nesta estrutura. Segundo a autora, o foco entonacional é pressuposicional, pois a partir dele pode-se pressupor a questão sob discussão. No par questão/resposta a seguir, a prosódia da resposta restringe as questões a que ela pode responder.

(17) A: Quem a Maria convidou?

B: A Maria convidou O JOÃOF.

B': \#A MARIA F convidou o João.

No contexto em (17), a resposta em B' não é apropriada para a pergunta $\mathrm{A}$, pois o constituinte "A Maria", que recebe acento de foco, corresponde a uma informação dada pela questão. Pragmaticamente, o constituinte que receber tal acento deve corresponder à informação nova, exatamente o que ocorre na resposta em B, por isto B é apropriada e B' não.

Assim como as questões, as asserções também apresentam um conjunto de 
alternativas e são denominadas alternativas de foco ${ }^{35}$ As alternativas de foco são calculadas a partir da localização do acento prosódico de foco na sentença. No que diz respeito à sentença (17)B, as alternativas de foco consistem na substituição do constituinte focado por uma variável, “A Maria convidou x". A variável, então, pode ser substituída por cada elemento do domínio. Se, para o contexto acima temos os seguintes elementos no domínio: $\mathrm{D}=\{$ João, Pedro, Marcos\}, o conjunto de alternativas de foco corresponde à:

(18) $[[$ A Maria convidou O JOÃO $F]=\{$ A Maria convidou o João, A Maria convidou o Pedro, A Maria convidou o Marcos $\}$

O conjunto de alternativas de foco equivale ao conjunto de alternativas da questão em A:

(19) $[[$ Quem a Maria convidou?] $]=\{$ A Maria convidou o João, A Maria convidou o Pedro, A Maria convidou o Marcos\}

Esta equivalência está relacionada à noção de congruência. Uma resposta é congruente a uma questão se o conjunto de alternativas de foco da resposta equivale ao conjunto de alternativas da questão.

Uma resposta pode não responder exatamente à questão explícita, mas parcialmente ou contrastivamente. Tais respostas geralmente vêm marcadas por dois contornos entonacionais. Para estes casos, Roberts retoma os exemplos de Jackendoff (1972) com a marcação das curvas entonacionais baseadas em Pierrehumbert \& Hirschberg (1990). Estes são apresentados a seguir:

(20) a. $\left[\mathrm{John}_{\mathrm{F}}\right]_{\mathrm{L}-\mathrm{H}}[\text { ate beans } \mathrm{F}]_{\mathrm{L}-\mathrm{L}}$

b. $\left[\mathrm{John}_{\mathrm{F}}\right]_{\mathrm{L}-\mathrm{L}}[\text { ate beans }]_{\mathrm{L}-\mathrm{H}}$

De acordo com Roberts, as duas sentenças pressupõem uma super-questão como "Who ate what?" e a respondem parcialmente. Porém o falante em (20)a utiliza a estratégia de responder a uma sub-questão como "What did John eat?", enquanto (20)b responde a uma sub-questão como "Who ate beans?". Os acentos distintos indicam, portanto, estratégias diferenciadas para responder à super-questão e pressupõem a questão sob discussão. Casos

\footnotetext{
${ }^{35}$ Conceito dado por Rooth (1985), também chamado de valor de foco.
} 
como este, de sentenças com dois acentos entonacionais foram discutidos por Büring (1999) e (2003) e serão apresentados brevemente nas seções seguintes.

A teoria da estrutura informação apresentada por Roberts, juntamente com a relação sub-questão/super-questão e as estratégias de resposta utilizadas pelos falantes subsidiarão nossa análise de respostas sobreinformativas a ser apresentada mais adiante, na seção 2.6.

\subsection{TÓPICO CONTRASTIVO 1: BÜRING (1999)}

Daniel Büring, em seu artigo sobre tópico de 1999, discute alguns conceitos em relação a elementos discursivos como tópico e foco que são importantes para nosso estudo. Em especial, ele apresenta uma proposta de interpretação de tópico que abrange tópicos contrastivos (em que o falante muda a direção da conversa) e tópicos parciais (em que o falante responde apenas parte do que foi solicitado). Esta seção é dedicada a uma breve apresentação da teoria de Büring e como ela pode contribuir para este estudo e para avanços com relação a outros fenômenos da língua.

Büring parte do princípio de que sentenças são formadas pelo par de componentes informacionais: foco/background. No background está contido o tópico, que como já vimos, é a informação dada, a pressuposição. Foco, por sua vez, é a informação nova que é solicitada pela questão e introduzida pela resposta. $\mathrm{O}$ autor se vale da semântica de foco dada por Rooth (1985), denominada valor de foco. No contexto abaixo, com um par questão/resposta, podemos identificar os componentes do discurso.

(21) A: Que livro o João comprou?

B: O João comprou $_{T} \backslash \mathrm{O}$ DE LINGUÍSTICA ${ }_{F}{ }^{36}$

Em (21)B, o constituinte que traz a informação nova e representa o foco da sentença é o NP "O João". O tópico, que contém a informação dada pela questão é a pressuposição de que "O João comprou algum livro". O valor de foco da sentença (21)B, segundo Rooth, é o conjunto de proposições possíveis para a resposta em (21)A. Veja a representação do valor de foco de (21)B abaixo, considerando que os elementos disponíveis no discurso sejam: livro de

\footnotetext{
${ }^{36}$ As notações adotadas são as mesmas utilizadas por Büring (1999), em que o símbolo "/" representa um pico de acento com curva ascendente, que identifica tópico e o símbolo " " representa o pico de acento com curva descendente, que identifica foco. "T" subscrito indica o constituinte com função discursiva de tópico e F subscrito, o constituinte com função discursiva de foco.
} 
linguística, livro de literatura.

(22) $\llbracket(21) B \rrbracket^{\mathrm{f}}=\{\mathrm{O}$ João comprou o livro de linguística, O João comprou o livro de literatura\}

O conjunto de proposições acima contém a proposição (21)B, portanto, uma resposta adequada, ou congruente, para o contexto dado acima. Entretanto, Büring observa que o valor de foco, não é capaz de delimitar alternativas de respostas para contextos com tópicos contrastivos ou parciais, por exemplo. Um tópico contrastivo ocorre quando o falante deseja mover a conversação para uma entidade diferente à dada no discurso. Já o tópico parcial não responde exaustivamente ao que foi requerido, mas apenas a uma parte da questão.

(23) A: Que livro os alunos compraram?

B: /O JOÃO ${ }_{T}$ comprou $\backslash O$ DE LINGUÍSTICA $F$

(24) A: Que livro o João comprou?

B: Bom, /O PEDRO ${ }_{T}$ comprou $\backslash O$ DE LINGUÍSTICA $F$

Os exemplos acima representam o que Büring denomina respectivamente de tópico parcial e tópico contrastivo. No primeiro, em (23), o falante B não responde totalmente à pergunta feita por $\mathrm{A}$, mas apenas à informação que corresponde a um indivíduo do conjunto de alunos, “João". Já em (24), o falante B não responde ao que é solicitado é dá uma informação referente a um elemento novo no contexto, "Pedro". Em ambos os casos, a resposta obtida não representa a esperada.

O autor também identificou que para a resposta ser apropriada nos contextos acima foram necessários dois acentos prosódicos distintos: o acento de foco, que tem como característica um pico de acento descendente; também um acento típico de tópico, que tem seu pico com curva ascendente. Sem estes, as construções seriam inadequadas. O constituinte que recebe o acento de tópico foi denominado S-topic. ${ }^{37}$ Além disso, as duas respostas parecem desenvolver implicaturas de ignorância, em que o falante, ao responder a questão, por não saber de todas as informações, responde apenas a respeito de um elemento, no caso de (23) ou muda a direção da conversa e responde a respeito de outro elemento que não estava no

\footnotetext{
${ }^{37}$ Em Büring (2003), o autor denomina S-topic de acento de tópico contrastivo (CT).
} 
contexto, como em (24). ${ }^{38}$ As respostas obtidas não fazem parte do valor de foco. Observe, abaixo, o valor de foco para (23)B e (24)B, respectivamente:

(25) $\llbracket(23) B \rrbracket^{\mathrm{f}}=\{$ João e Pedro compraram o livro de linguística, João e Pedro compraram o livro de literatura, João comprou o livro de linguística e Pedro o de literatura, João comprou o livro de literatura e Pedro o de linguística $\}^{39}$

(26) $\llbracket(24) B \rrbracket^{\mathrm{f}}=\{\mathrm{O}$ João comprou o livro de linguística; O João comprou o livro de literatura\}

Note que em (25) não há uma proposição do tipo "O João comprou o livro de linguística", resposta dada em (23)B. As proposições possíveis são apenas de respostas completas, sem apresentar uma proposição de resposta parcial, como ocorre no exemplo acima. O valor de foco de (24)B, apresentado em (26) também não apresenta a proposição obtida como resposta "O Pedro comprou o livro de linguística", mas somente respostas relacionadas ao indivíduo "João".

Para ser possível calcular o valor semântico de sentenças como as apresentadas acima, Büring definiu o valor de tópico, que representa um conjunto de questões, ou um conjunto do conjunto de proposições possíveis para determinado contexto. Para cada elemento disponível, há um conjunto de proposições. A soma destes conjuntos consiste no valor de tópico da sentença. Para (23)B, por exemplo, suponhamos que o conjunto de alunos seja formado pelos indivíduos: João e Pedro. Para cada indivíduo há um conjunto de proposições. Para João: \{O João comprou o livro de linguística, O João comprou o livro de literatura\}. Para Pedro: \{O Pedro comprou o livro de linguística, O Pedro comprou o livro de literatura\}. O valor de tópico de (23)B, portanto é a junção destes conjuntos, como segue:

(27) $\llbracket(23) B \rrbracket^{t}=\{\{\mathrm{O}$ João comprou o livro de linguística, O João comprou o livro de literatura $\},\{\mathrm{O}$ Pedro comprou o livro de linguística, O Pedro comprou o livro de literatura $\}$ \}

Como cada conjunto representa o valor ordinário de uma questão, a denotação do

\footnotetext{
${ }^{38}$ Em Büring (2003), o autor assume que a implicatura pode ser de ignorância, em que o falante não sabe se a propriedade $p$ pertence ao elemento $x$, ou de que o falante sabe que a propriedade $p$ não pertence ao elemento $x$, conforme Gazdar (1979).

${ }^{39}$ Considera-se que no domínio, há os seguintes indivíduos: \{João, Pedro, livro de linguística, livro de literatura\}
} 
valor de tópico de (23)B pode ser representada por um conjunto de questões.

(28) $\llbracket(23) B \rrbracket^{t}=\{$ Que livro o João comprou?, Que livro o Pedro comprou?\}

Com a formalização do valor de tópico, o autor define a condição do par questão/resposta:

(29) O valor ordinário de uma questão deve pertencer a um elemento do valor de tópico da resposta $\left(\llbracket Q \rrbracket^{0} \varepsilon \llbracket A \rrbracket^{\mathrm{T}}\right)$.

Retomemos ao nosso exemplo em (24), repetido a seguir, para verificar se este satisfaz a condição do par questão/resposta:

(30) A: Que livro o João comprou?

B: /O PEDRO comprou $\backslash O$ DE LINGUÍSTICA $_{F}$

No contexto em (30), o valor ordinário da questão A representa um elemento do valor de tópico de B. Vejamos abaixo:

(31) $\llbracket(30) A \rrbracket^{0}=\{\mathrm{O}$ João comprou o livro de linguística, O João comprou o livro de literatura\}

(32) $\llbracket(30) B \rrbracket^{\mathrm{T}}=\{$ Que livro o João comprou?, Que livro o Pedro comprou?\}

Notemos que o valor ordinário de (30A) está contido no valor de tópico de (30B). O valor semântico da questão “Que livro o Pedro comprou?", que faz parte do valor de tópico, é um conjunto de alternativas que contém "O Pedro comprou o livro de linguística". A resposta é adequada e satisfaz a condição do par questão/resposta. Tal condição está relacionada à noção de congruência de Roberts (1996) apresentada na seção anterior. No entanto, Büring afirma para uma resposta ser congruente, o valor semântico ordinário da questão deve pertencer ao valor de tópico de sua resposta e não ao valor de foco, como assume Roberts. ${ }^{40}$

\footnotetext{
40 Para o contexto em (23), em que há um contexto de tópico parcial, o valor de foco corresponde a (considerando o domínio: $\mathrm{D}=\{$ João, Pedro, livro de linguística, livro de literatura $\}$ ):

$[[23 \mathrm{~B}]]^{\mathrm{f}}=\{$ João e Pedro compraram o livro de linguística, João e Pedro compraram o livro de literatura, João
} 
Outro tipo de tópico, a que Büring chama de tópico puramente implicacional, é apresentado a seguir.

(33) A: A sua esposa foi pra festa?

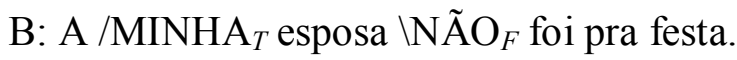

A sentença (33), a não ser pelo acento de tópico, responde exatamente ao requerido pela questão em A, pois o valor de foco de (33)B é o seguinte:

(34) $\llbracket(33) B \rrbracket^{f}=\{\text { A minha esposa foi pra festa; A minha esposa não foi pra festa }\}^{41}$

Como pudemos observar, a resposta dada em (33)B pertence ao seu valor de foco. No entanto, o acento ascendente no constituinte de tópico em B indica que o falante deseja trazer ao contexto questões alternativas. Responde ao que A pergunta, mas deixa no ar questões como: A esposa de Pedro foi pra festa?; A esposa de Marcos foi pra festa?; A esposa de $\mathrm{x}$ foi pra festa?... Estas questões podem determinar a continuidade da conversação. Mais formalmente teríamos o valor de tópico a seguir.

(35) $\llbracket(33) \mathrm{B} \rrbracket^{\mathrm{t}}=$ \{A minha esposa foi pra festa?; A esposa do Pedro foi pra festa?; A esposa do Marcos foi pra festa?\}

Uma diferença essencial de sentenças como (33) para as anteriores é que, enquanto para identificar a implicatura de sentenças com tópico parcial ou contrastivo era necessário olhar para o contexto anterior, implicaturas de sentenças puramente implicacionais determinam o rumo da conversação após a pronúncia da sentença.

É interessante destacar que em todos os contextos até aqui mencionados há certa regularidade em relação ao acento prosódico utilizado, em que os constituintes de foco

comprou o livro de linguística e o Pedro o de literatura, João comprou o livro de literatura e o Pedro o de linguística\}

E o seu valor de tópico é o seguinte:

$[[23 \mathrm{~B}]]^{t}=\{$ Que livro o João comprou?, Que livro o Pedro comprou?, Que livro o João e o Pedro compraram?\}

A resposta em 23 é congruente com seu valor de tópico, já que a proposição "o João comprou o livro de linguística" é um elemento contido no valor ordinário da questão “Que livro o João e o Pedro compraram?”, já que a soma dos indivíduos Pedro e João corresponde ao conjunto de alunos neste contexto.

${ }^{41}$ Como o contexto (33) apresenta um exemplo de pergunta polar, em que há duas possibilidades de resposta: sim ou não, o valor de foco é constituído por uma proposição positiva e outra negativa. Ainda, nestes casos, no $\mathrm{PB}$, o acento prosódico que indica o elemento de foco recai sobre o elemento negativo, se a resposta for negativa, ou no verbo da sentença, se a resposta for positiva. 
recebem o acento descendente e os constituintes de tópico o acento ascendente, o que demonstra a relevância do trabalho de Büring.

A seguir, veremos um pouco mais da proposta de Büring, em um trabalho posterior, no qual o autor toma como ponto de partida a teoria de Roberts (1996) em relação às estratégias do discurso para aprofundar ainda mais sua teoria sobre tópicos contrastivos e parciais.

\subsection{TÓPICO CONTRASTIVO 2: BÜRING (2003)}

Em Büring (2003), o autor assume uma estrutura tripartite para marcações de acentos entonacionais em sentenças. Para ele, há casos em que determinado constituinte na sentença é marcado por um acento de foco $(\mathrm{F})$, em outros, o constituinte recebe um acento de tópico contrastivo (CT), e nos demais casos, nenhuma marcação ocorre. O que ele chama de marcação de tópico contrastivo neste artigo é uma marcação prosódica que abrange todos os fenômenos trabalhados em Büring (1999): tópico parcial, contrastivo e puramente implicacional.

Para Büring, a estrutura da informação pode ser dividida em duas partes, uma relacionada ao conteúdo e outra relacionada à forma. A primeira está diretamente ligada à informatividade da estrutura e considera apenas a soma das informações dadas no discurso (common ground). A última, por sua vez está relacionada ao conceito de relevância dado por Roberts (1996), em que a questão sob discussão vai indicar o que é relevante para dado contexto.

Partindo da teoria de Roberts, que propõe uma estrutura de relações de superquestões e sub-questões para a estrutura da informação, Büring desenvolve o que ele chama D-trees (árvores do discurso) para organizar as relações entre questões e asserções. Abaixo, apresentamos um modelo de D-tree para a estrutura de questões apresentada anteriormente, em (16), repetida em (36) por conveniência:

(36) O que os alunos compraram?

a. O que o João comprou?

$$
\begin{gathered}
\mathrm{a}_{1} \text {. O João comprou livros? } \\
\text { Resposta }\left(\mathrm{a}_{1}\right) \text { : Sim. } \\
\mathrm{a}_{2} \text {. O João comprou roupas? }
\end{gathered}
$$


Resposta $\left(a_{2}\right)$ : Sim.

b. O que a Maria comprou?

$\mathrm{b}_{1}$. A Maria comprou livros?

Resposta $\left(b_{1}\right)$ : Não.

$\mathrm{b}_{1}$. A Maria comprou roupas?

Resposta $\left(b_{2}\right)$ : Sim.

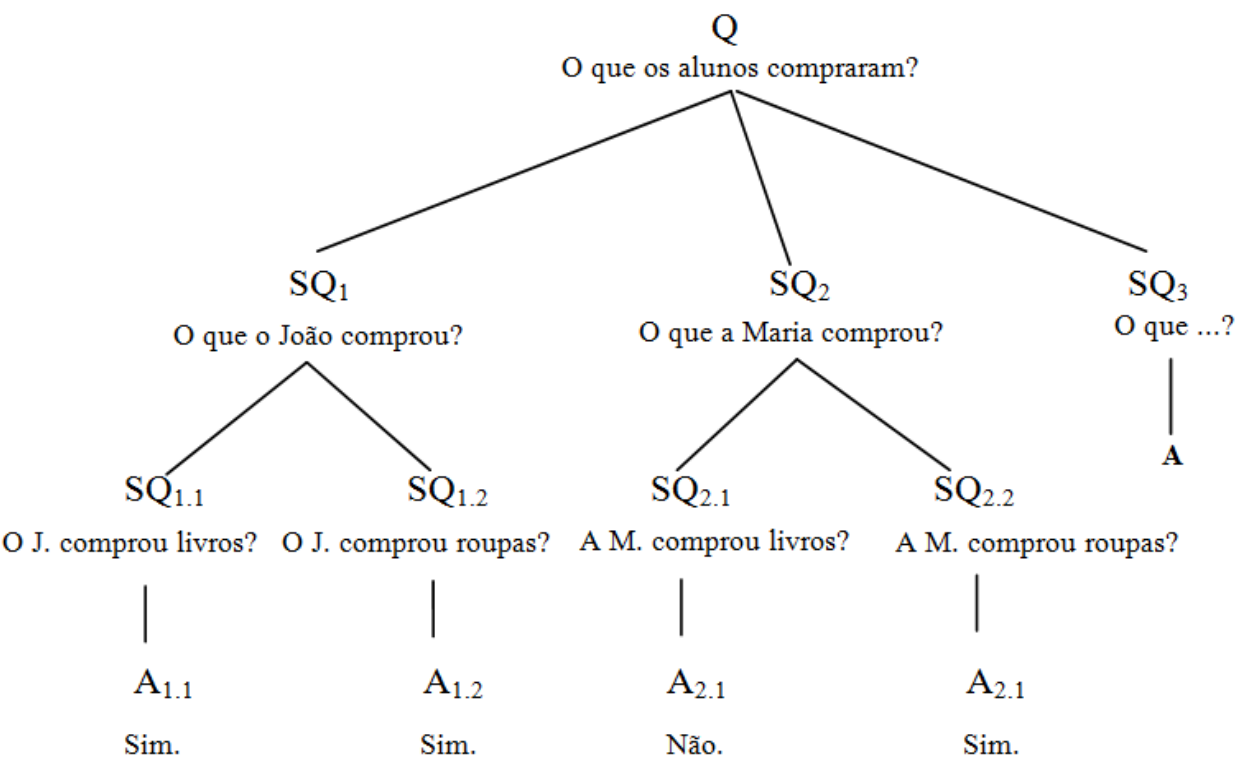

$\mathrm{Na}$ estrutura $d$-tree apresentada acima, cada nó representa um movimento do discurso que pode ocorrer uma sentença declarativa (A) ou interrogativa (Q ou SQ). Um movimento pode relacionar duas questões, como o movimento de $\mathrm{Q}$ para $\mathrm{SQ}_{1}$, em que $\mathrm{SQ}_{1}$ representa uma sub-questão de $\mathrm{Q}$, ou ainda, relacionar uma questão com uma asserção $\left(\mathrm{SQ}_{3}-\mathrm{A}\right)$. Neste caso, a asserção deve responder à questão que imediatamente a domina. Diante destas relações na $d$-tree, Büring redefine relevância como segue:

(38) Relevância:

c. Uma asserção $A$ é relevante em uma $d$-tree $D T$ sse $A$ é uma resposta para a questão sob discussão $Q U D$.

d. Uma questão $Q$ é relevante em um $d$-tree $D T$ sse ao menos uma resposta para $Q$ é uma resposta para a questão sob discussão $Q U D$.

Será relevante para o discurso uma asserção que represente uma resposta (completa ou parcial) para a questão sob discussão de determinada $d$-tree. No caso do exemplo em (37), 
uma asserção relevante para o discurso, seria a resposta completa $\mathrm{A}_{1.1}$ "sim", para a subquestão $\mathrm{SQ}_{1.1}$, que por sua vez é uma resposta parcial para $\mathrm{SQ}_{1}$ e consequentemente para $\mathrm{Q}$. Se for uma questão, esta será relevante para o discurso se pelo menos uma resposta para esta questão seja uma resposta para a questão sob discussão. Mais uma vez retomando ao nosso exemplo, $\mathrm{SQ}_{1}$ é relevante para o discurso porque a resposta para esta questão representa uma resposta parcial para Q.

O conceito de relevância considera a estrutura vertical da árvore, as relações de subquestão e super-questão, sem se importar em diferenciar sub-questões irmãs. Informatividade, por outro lado, que está relacionada ao conteúdo do discurso, está ligada à estrutura linear de d-tree e não se importa em diferenciar sub-questão de super-questão e sim com a soma de todos os movimentos precedentes (common ground).

Diante desta definição de estrutura de árvore para o discurso e da divisão da estrutura da informação em duas partes: forma e conteúdo, Büring apresenta dois princípios que norteiam o uso de marcadores de CT: CT-congruence e Givenness. O primeiro é voltado para a estrutura hierárquica da informação (a forma) e determina que um enunciado só pode conter uma marcação de tópico contrastivo $C T$ se este indica ao menos uma estratégia dentro da $d$ tree para um determinado movimento.

Büring, entretanto, chama a atenção para os casos em que o falante não responde exatamente à questão explícita, como já havia apresentado em seu trabalho anterior, de 1999. Nestes casos, o falante dá uma resposta parcial: tópico parcial, ou dá uma resposta diferente da que foi perguntada: tópico contrastivo. Voltando à estrutura em (37), se a resposta para a super-questão for parcial, o constituinte "O João" receberá o acento CT, como apresentado abaixo:

(39) A: O que os alunos compraram?

B: O JOÃO ${ }_{C T}$ comprou LIVROS $_{F}$.

Em (39), o falante A não responde exatamente ao que foi questionado, portanto o valor de foco de B não é equivalente ao conjunto de alternativas de $\mathrm{Q}$, mas responde a uma sub-questão da pergunta em A do tipo “O que o João comprou?”. A este tipo de estratégia, Büring denomina movimento implícito e chama a atenção para o marcador de CT que é obrigatório neste caso. 
(40) A: O que os alunos compraram?

(O que o João comprou?)

B: O JOÃO ${ }_{C T}$ comprou LIVROS $_{F}$.

B': \#O João comprou $\operatorname{LIVROS}_{F}$.

A asserção em B' não é uma resposta congruente com a questão em A. Para responder a uma questão implícita, já que B não responde A e sim uma sub-questão dela (apresentada entre parênteses), o falante deve fazer uso do marcador de CT, o que indica que está utilizando uma estratégia e não respondendo diretamente à pergunta explícita.

O segundo princípio, que já havia sido definido por Schwarzchild (1999) e é reformulado por Büring, diz respeito à Givenness. Segundo tal princípio, todo constituinte que não é dado no discurso deve ser marcado ou com um marcador de foco (F) ou de tópico contrastivo (CT). De acordo com Büring, o marcador de CT é obrigatório apenas nos casos em que há uma estratégia de discurso. Marcador de foco (F) será utilizado apenas em contextos em que o falante não faz uso de nenhum tipo de estratégia para responder ao questionado.

Por último, Büring apresenta um exemplo de contexto em que uma determinada asserção pode representar uma resposta completa para uma super-questão Q. Nestes casos, tal resposta será diretamente dominada pela super-questão e, portanto, não pode receber acento de CT. Para ficar mais claro, apresentamos um exemplo abaixo similar ao de Büring.

(41) Q: Quantos alunos foram aprovados?

$S Q_{1}$ : (Alguns alunos foram aprovados?)

$\mathrm{A}_{1}: \mathrm{ALGUNS}_{C T}$ alunes foram aprovades.

$\mathrm{SQ}_{2}$ : (A maioria dos alunos foram aprovados?)

$\mathrm{A}_{2}$ : A MAIORIA ${ }_{C T}$ des alunos foram aprovados.

$S_{3}$ : (Todos os alunos foram aprovados?)

$\mathrm{A}_{3}$ : \#TODOS $\mathrm{TT}_{C T}$ es alunos foram aprovados.

Em (41), a resposta em $\mathrm{A}_{3}$ não pode receber marcação de CT para responder $\mathrm{Q}$, isto porque $\mathrm{A}_{3}$ representa uma resposta completa para $\mathrm{Q}$, sem a necessidade de responder uma sub-questão implícita, como em $\mathrm{A}_{1}$ ou $\mathrm{A}_{2}$. Então, segundo Büring, na d-tree que a representa tal contexto, a asserção $\mathrm{A}_{3}$ está ligada diretamente à questão $\mathrm{Q}$, como ilustrado abaixo: 


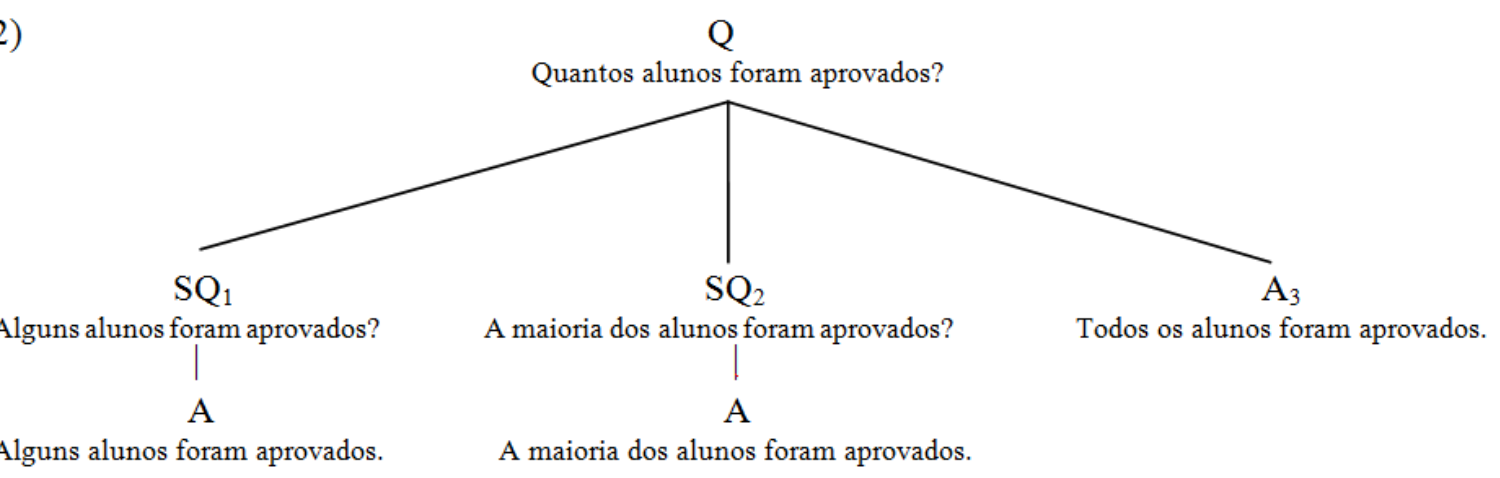

Para o autor, a função principal de um marcador de CT (tópico contrastivo) é indicar uma estratégia do discurso. Identificar se o constituinte marcado trata-se de informação nova ou dada torna-se, então, uma função secundária. De acordo com Büring, a marcação de CT não está diretamente ligada a conceitos mais abstratos de tópico e foco. Para ele marcação de CT está mais relacionada à indicação de uma estratégia do que a identificar se o constituinte marcado trata-se de uma informação dada ou nova no discurso.

As propostas de Büring (1999) e (2003) vistas resumidamente aqui abrangem todos os casos mencionados. Entretanto, contextos com respostas mais informativas do que as solicitadas, como os que vimos anteriormente, diferenciam-se prosodicamente dos casos de Büring e não recebem o mesmo acento de tópico apresentado pelo autor.

(43) A: O João foi pra festa?

B: \TODO MUNDO foi pra festa.

Em (43), o acento que o quantificador universal recebe não é o mesmo de $S$-topic, ou CT (tópico contrastivo), que tem seu pico de acento ascendente. A entonação é descendente, mais alta no início da pronúncia do quantificador e vai diminuindo. O marcador de CT, portanto não é compatível com contextos de respostas sobreinformativas como a acima. Além disso, o falante, ao responder B, não responde a uma sub-questão de A e sim a uma superquestão do tipo “Quem foi pra festa?”, o oposto das relações apresentadas por Büring. Ainda, a implicatura gerada com o uso desta estratégia, em que o falante julga ser relevante dar mais informação do que o solicitado, não se parece com as implicaturas geradas por construções anteriores como ignorância da parte do falante.

Estas diferenças prosódicas e semântico/pragmáticas nos levam a afirmar que estamos diante de um fenômeno não contemplado pela teoria de Büring. A proposta, então é, 
na próxima seção, buscar uma alternativa que contemple contextos com respostas sobreinformativas, que trazem informações além das requeridas.

\subsection{ESTRATÉGIAS DE RESPOSTAS SOBREINFORMATIVAS EM PORTUGUÊS}

Nesta seção, serão observadas estratégias de respostas sobreinformativas em que parece ocorrer um fenômeno oposto aos exemplos de Büring. Enquanto nas respostas parciais de Büring, o falante opta pela estratégia de responder a uma sub-questão implícita de uma pergunta mais geral, nas respostas sobreinformativas, o falante opta por responder uma superquestão de uma questão mais restrita colocada explicitamente no contexto.

Observaremos o fenômeno de respostas sobreinformativas primeiramente em perguntas polares, aquelas em que a resposta esperada resume-se aos elementos sim/não. Após, com perguntas de constituinte, em que o foco da resposta seja um constituinte e, por fim, em contextos de perguntas implícitas, em que não há uma questão explícita, dada pelo discurso. Serão analisadas sentenças com constituintes sobreinformativos nas posições de argumento externo, argumento interno e em sentenças com verbos bitransitivos.

\subsubsection{Com perguntas polares}

Perguntas polares são aquelas que têm como resposta esperada um dos dois elementos: sim, para resposta afirmativa e não para resposta negativa. Um exemplo de contexto com pergunta polar foi apresentado anteriormente e será repetido abaixo:

A: O João foi pra festa?

B: \TODO MUNDO foi pra festa.

A resposta para a pergunta em (44) poderia apenas ser a afirmativa "sim". Em português brasileiro é bastante comum o falante repetir o verbo, indicando a afirmação na resposta. No caso do exemplo acima, a resposta poderia ser: "foi", significando que João foi pra festa. No entanto, o falante opta por responder com o quantificador universal generalizado "todo mundo". Em um contexto em que os funcionários de determinada empresa foram convidados para uma festa, Carlos quer saber se o João foi e pergunta pra Paulo o que está em (44). A resposta em B acarreta a resposta solicitada, que João foi pra festa e, além disso, traz informações a mais sobre os demais convidados da festa. Ou seja, a propriedade que se aplica 
ao João não é exclusiva dele e sim de todas as pessoas salientes no contexto. É como se ficasse implícito algo do tipo: "o João foi, e além dele" e então o falante responde explicitamente "TODO MUNDO foi pra festa". Neste contexto, o Paulo acredita que seja mais relevante para o discurso dar informação de que todos os funcionários foram pra festa. Com essa declaração, ele responde automaticamente a perguntas do tipo: O Pedro foi pra festa? O Marcos foi pra festa?... Imaginemos que a festa foi um sucesso e há um interesse de Paulo de mostrar que todos participaram da festa. Ao declarar a resposta sobreinformativa, ele deseja enfatizar a importância da propriedade em questão, que é aplicada a todos os funcionários convidados para a festa.

De acordo com a teoria da estrutura da informação, de Roberts (1996), o falante, ao responder (44)A, dá uma resposta completa para a super-questão que domina a questão sob discussão. Ou seja, ao responder outra questão, ao invés da questão explicitamente colocada no discurso, o falante muda o que é relevante para o discurso. Segundo a proposta de Roberts, a relevância está atrelada à questão sob discussão (QUD). No contexto criado acima, a questão sob discussão posta no discurso era “O João foi pra festa?”. No entanto, o falante B se utiliza da estratégia de responder completamente a uma pergunta do tipo "Quem foi pra festa?". Tal estratégia indica que o falante mudou a questão sob discussão. Em vez de simplesmente responder ao perguntado, resolveu responder a uma questão mais ampla. A partir desta estratégia, o falante deixa claro que o que é mais relevante pra ele é responder completamente a uma questão mais geral do que simplesmente responder à questão dada, já que tem informações sobre todos os convidados da festa. Como a questão mais ampla acarreta a questão dada explicitamente, o falante também a responde e, além disso, responde a suas questões irmãs, se pensarmos na estrutura hierárquica da árvore do discurso $(d$-tree $)$ proposta por Büring (2003).

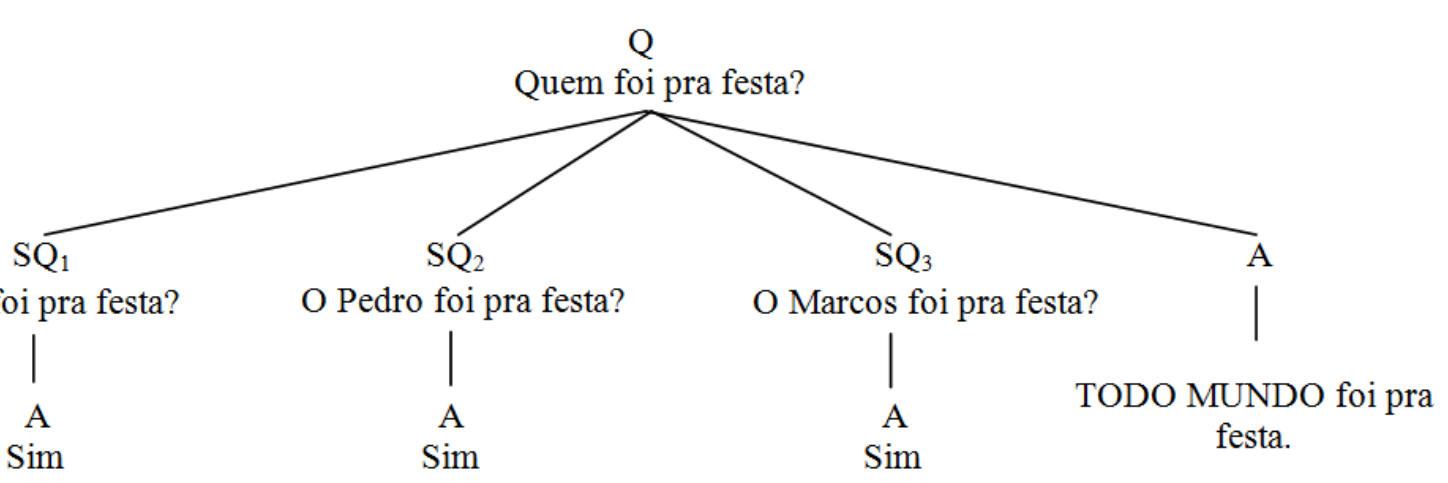

Repare que o falante, ao dar a resposta sobreinformativa, responde completamente a 
uma questão mais ampla como indicada em Q na d-tree acima. A questão Q, desta forma, domina diretamente a resposta "TODO MUNDO foi pra festa". O falante, com tal resposta, quer deixar claro que a propriedade em discussão não é exclusiva do indivíduo "João", mas pertence a todos os indivíduos do conjunto.

Quanto ao acento prosódico, diferentemente dos exemplos constantes em Büring (1999) e (2003), não há nenhum constituinte que receba o acento ascendente, característico de CT (tópico contrastivo). Sendo assim, não há constituinte que receba esta função. O verbo recebe um acento descendente de foco de informação e o sintagma introduzido pelo quantificador recebe também um acento descendente. Se considerarmos que a informação trazida pelo quantificador representa uma informação nova, podemos concluir que o constituinte introduzido pelo quantificador universal tem a função informativa de foco. No entanto, vale lembrar que, segundo Büring (2003), o falante só faz uso do marcador de CT(tópico contrastivo) quando quer indicar uma estratégia do discurso. Quando o falante dá uma resposta como (44), com informações além da requerida, ele também faz uso de uma estratégia, porém não é a mesma indicada pelo marcador de CT, mas oposta. O acento que o constituinte sobreinformativo recebe, portanto, não deve ser canônico de foco, mas um específico que indique tal estratégia. Parece que o acento de foco em respostas sobreinformativas é distinto de um acento de foco meramente informacional. Compare os dois contextos abaixo:

(46) A: Quem foi pra festa?

B: TODO $\mathrm{MUNDO}_{F}$ foi pra festa.

(47) A: O João foi pra festa?

B: TODO MUNDO foi pra festa.

No contexto (46), o falante B responde completamente a uma pergunta explícita, sem necessidade de fazer uso de estratégia. Já em (47), ao dar uma resposta sobreinformativa, o falante se utiliza de uma estratégia que indica que está respondendo à outra pergunta, mais abrangente do que a dada, que acarreta esta última. Parece que há uma diferença sutil de acentuação prosódica. Enquanto no contexto (46) não há necessidade de uso de estratégia e o acento de foco (F) é o mesmo de Büring (2003), em (47) parece haver uma curva prosódica distinta, o que pode sinalizar o uso de uma estratégia por parte do falante. Tal distinção entonacional é bastante sutil e merece um estudo mais aprofundado sobre as diferenças 
prosódicas de um marcador de foco canônico em um marcador de foco para respostas sobreinformativas. No presente estudo, propomos que este último trata-se de um marcador de foco sobreinformativo (FS). Com isso, defendemos, diferentemente de Büring, que além das marcações F e CT, um constituinte pode também receber um acento prosódico do tipo FS, de foco sobreinformativo. Daqui em diante, portanto, faremos referência à marca prosódica do constituinte sobreinformativo como FS. Ressaltamos que tal marcação de foco, assim como CT de Büring, diz respeito ao acento prosódico que recai sobre o foco sobreinformativo e tem duas funções. A primeira, que é a função principal de FS, consiste em indicar uma estratégia no discurso e a segunda, identificar o constituinte marcado como uma informação nova no discurso. Portanto tal conceito é diferente dos conceitos de foco apresentados anteriormente por Zubizarreta (1998), Erterschik-Shir (2007) e outros.

Como vimos, os conceitos de foco contrastivo e restritivo de Erteschik-Shir (2007) são diferentes do que estamos chamando neste trabalho de foco sobreinformativo. Foco contrastivo para a autora realiza uma função em um conjunto de elementos determinado pelo contexto. Tal função consiste em destacar um elemento do contexto dado e eliminar os demais. A proposta de Zubizarreta (1998), assumida por Mioto (2003) também distancia do tipo de foco que identificamos nesta pesquisa. Enquanto na proposta destes autores o constituinte focalizado elimina ou nega o constituinte dado, no caso das respostas sobreinformativas, o elemento focalizado representa um conjunto que inclui o elemento dado. $\mathrm{Na}$ verdade há um contraste no foco sobreinformativo, porém, este se dá a partir da nãoexaustividade do elemento dado em relação à propriedade em questão. Voltando ao nosso exemplo, o falante, ao dar a resposta sobreinformativa quer mostrar que a propriedade de ir à festa não exclusiva de "João", com isso contrasta a não-exaustividade de tal propriedade em relação a "João".

O que denominamos foco sobreinformativo aqui, portanto, diz respeito a um elemento que tem a função de contrastar a não exaustividade de uma propriedade em relação ao elemento dado pelo contexto e incluir todos os elementos de determinado conjunto saliente no contexto. Ainda, FS não representa o constituinte de foco em si, mas a marcação prosódica que recai sobre este constituinte para primeiramente indicar uma estratégia de discurso utilizada pelo falante e, além disso, identificar uma informação nova. Tal informação é confrontada com informações já presentes no contexto, sem que estas tenham de ser negadas. Com relação à posição sintática deste constituinte com marcação de foco sobreinformativo, assumiremos a proposta de Mioto (2003), que defende que constituintes com função de foco com um traço semântico movem-se para uma posição de FocP na periferia esquerda da 
sentença. Esses traços semânticos podem ser contrastivos ou exaustivos, que já haviam sido apresentados por ele, ou sobreinformativos, um outro tipo de foco identificado nesta pesquisa. (as relações sintáticas serão discutidas no capítulo 3).

Com relação às respostas sobreinformativas, o falante, ao fazer uso da marcação de FS, indica que está respondendo a uma super-questão da explicitada no contexto, a fim de mostrar que a propriedade em discussão não é exclusiva do elemento dado, mas de todos os elementos do conjunto do qual faz parte. Se retomarmos as funções de tópico ou foco restritivo de Erteschik-Shir, veremos que a estratégia de respostas sobreinformativas realiza uma operação oposta às definidas pela autora para tópico ou foco restritivo. Vejamos o exemplo abaixo similar aos dados por Erteschik-Shir (2007):

(48) A: Quais de seus amigos foram pra festa?

B: /O JOÃO ${ }_{C T}$ foi (pra festa).

Lembremos que em contextos como acima, os constituintes a que Erteschik-Shir denomina de tópico restritivo, Büring (1999) chama de tópico parcial. Em Büring (2003), o autor considera que tópicos restritivos e contrastivos (na denominação de Erteschik-Shir) recebem a marcação prosódica de CT (contrastive topic). No contexto acima, Erteschik-Shir defende que ocorre uma operação complexa do discurso, em que primeiramente o conjunto de amigos é destacado e dentro deste conjunto, o indivíduo "João" é focalizado e destacado no contexto. A autora formaliza tal operação como segue:

(49) $\left[\left\{\text { João }_{\text {foc }}, \text { Pedro, Marcos... }\right\}_{\text {top }}\right]_{\text {top }}[\text { foi pra festa }]_{\text {top }}$

Em uma resposta sobreinformativa, a operação que ocorre parece ser um alargamento de domínio, em que a função do acento de foco sobreinformativo é destacar um elemento dado pelo contexto e, a partir deste elemento, expandir o domínio para todo o conjunto a que tal elemento faz parte. Então, focaliza todo o conjunto e o destaca no contexto. Retomemos ao exemplo de resposta sobreinformativa dado inicialmente e consideremos que o conjunto de convidados para a festa seja formado pelos seguintes elementos: João, Pedro e Marcos.

(50) A: O João foi pra festa?

B: \TODO MUNDO $F S$ foi pra festa. 
No contexto acima, a estratégia foi, a partir do elemento "O João", expandir o domínio a todos os elementos do conjunto a que "João" faz parte, no caso, todos os funcionários convidados para a festa, e trazer este conjunto para o contexto. Tal conjunto é representado pelo quantificador generalizado "todo mundo". A partir da formalização dada Erteschik-Shir (2007), propomos a seguinte operação:

(51) $\left[\{\text { João }\}_{\text {top }} \text {, Marcos, Pedro (TODO MUNDO) }\right]_{\text {foc }}[\text { foi pra festa }]_{\text {top }}$

A representação acima indica que houve uma operação complexa em que, a partir do elemento dado, pode-se destacar todo o conjunto a que tal elemento faz parte e este conjunto entra no contexto com uma marca de focalização.

Voltando às máximas conversacionais de Grice, apesar de num primeiro momento parecer que o falante em B não respeite a máxima da quantidade, em uma observação mais cuidadosa no contexto, pode-se perceber que o falante utilizou-se de uma estratégia, ao modificar a questão sob discussão para indicar o que pra ele era mais relevante no contexto. Considerou, a partir da máxima da relevância, que responder a uma super-questão, que domina a questão explicitada no discurso, era mais relevante do que responder apenas ao questionado.

Até aqui, observamos estratégias de respostas sobreinformativas apenas com a presença do quantificador universal distributivo "todo", que tem a função de distribuir certa propriedade para todos os elementos do conjunto em questão. Nestes contextos percebemos que o falante faz uso de tal estratégia para enfatizar uma propriedade positiva e mostrar que tal propriedade não é exclusiva do elemento em discussão, mas de todos os elementos pertencentes ao seu conjunto. Vejamos, a seguir, estratégias com quantificadores negativos, que têm a função negar que certa propriedade está presente nos elementos de determinado conjunto.

(52) A: O João foi pra festa?

B: \NINGUÉM $M_{F S}$ foi pra festa.

Para (52) pode-se pensar em um contexto parecido com anteriormente criado de que houve uma festa e os funcionários de certa empresa foram convidados. O Carlos quer saber se o João foi e pergunta pra Paulo o que está em B. A resposta acarreta que João não foi pra 
festa, já que ele faz parte do conjunto em questão. E mais ainda, traz a informação de que não foi apenas o João que não foi pra festa e sim de que em todo o conjunto de indivíduos saliente no contexto, não existe um sequer que tenha ido à festa. Imaginemos que Paulo era o organizador da festa e tinha muitas expectativas com relação a ela. No entanto, os convidados não foram e este fato causou uma frustração em Paulo. Com a resposta em B, Paulo quer demonstrar sua chateação e por isso acredita que é mais relevante responder à informação sobre todo o conjunto de funcionários, e não somente sobre o João. Responde completamente, então, a uma super-questão implícita do tipo “Quem foi pra festa?”. Assim, demonstra que esta propriedade negativa, de "não ter ido pra festa" não é exclusiva de "João", mas de todos os funcionários convidados. A árvore do discurso de (52) parece ser similar à anteriormente proposta para resposta com o quantificador universal, exceto que o falante responde negativamente para cada indivíduo do conjunto.

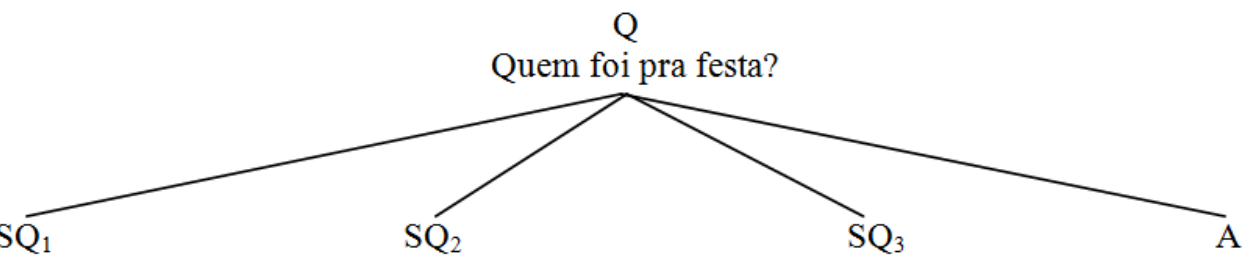

O João foi pra festa?

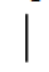

A

Não
O Pedro foi pra festa?

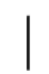

A

Não
O Marcos foi pra festa?

A

Não

O falante em (52) faz uso da estratégia de responder completamente à super-questão $\mathrm{Q}$, conforme ilustrado em (53). Responder à $\mathrm{Q}$ acarreta tanto a resposta de $\mathrm{SQ}_{1}$, explícita no discurso, quanto a resposta de suas questões irmãs, $\mathrm{SQ}_{2}, \mathrm{SQ}_{3}$ e $\mathrm{SQ}_{4}$. A curva prosódica com acento de FS indica tal estratégia do discurso. A marcação de FS, como no exemplo anterior, realiza uma função de alargamento do domínio, destacando no contexto, a partir do elemento dado, todo o conjunto de que este faz parte.

O contexto de estratégia sobreinformativa discutido até aqui apresenta o sintagma quantificado na posição de sujeito. Notamos que os mesmos fenômenos ocorrem com QPs em outras posições sintáticas. Observe a sequência de contextos a seguir.

(54) A: O João acertou a questão $n^{\circ} 5$ da prova?

B: O João acertou $\backslash$TODAS$_{F S}$ AS QUESTÕES DA PROVA. 
(55) A: O João doou seu livro de linguística pra biblioteca?

B: O João doou $\backslash$ TODOS ${ }_{F S}$ OS LIVROS DELE pra biblioteca.

(56) A: O João entregou presente pra Maria?

B: O João entregou presentes para $\backslash$TODAS$_{F S}$ AS CRIANÇAS DA FESTA.

Em todos os contextos acima, o falante, ao fazer uso da resposta sobreinformativa, pretende ressaltar que a propriedade em discussão não é exclusiva ao elemento dado. Em (54), o falante quer deixar claro que a propriedade "João acertar questões" não é exclusiva para a “questão no 5", mas para "TODAS AS QUESTÕES DA PROVA”. Em (55), a propriedade "João doar livros pra biblioteca" é aplicada a todo o conjunto de livros e não apenas ao "livro de linguística". Da mesma maneira, em (56), o falante enfatiza que "João entregar presentes" não é exclusiva para "Maria", mas para "TODAS AS CRIANÇAS DA FESTA".

Os falantes em B resolvem não apenas responder a questão dada, mas utilizar-se da estratégia de responder completamente a uma questão mais ampla, modificando, assim a questão sob discussão dada no discurso. A resposta para a questão acarreta a resposta para a questão explicitada. No entanto, os falantes deixam claro que a propriedade em discussão não é exclusiva para o elemento dado, mas para todos do conjunto ao qual faz parte.

As características prosódicas são as mesmas do exemplo anterior, há dois picos de acento de curva descendente na sentença, um de foco de informação que recai sobre o verbo, indicando afirmação, e outro que recai sobre sintagma quantificado na posição de objeto. Mais especificamente, a curva descendente recai sobre o determinante, enquanto o NP (“questões da prova" para (54), "livros dele" para (55) e "crianças da festa" para (56)) não apresenta curva entonacional. Se considerarmos que tal NP já é uma informação dada pelo contexto e que somente o determinante indica a informação nova, podemos explicar a ausência de uma curva entonacional no NP. Como há uma estratégia de discurso em jogo, podemos concluir que o determinante recebe um acento de foco sobreinformativo (FS) e tal acento, além de indicar uma estratégia, também identifica a informação nova no discurso. Tal acento realiza uma operação complexa em que, a partir do elemento identificado como tópico da sentença, ocorre um alargamento de domínio e todo o conjunto do qual o elemento dado faz é destacado no discurso.

Como nos demais contextos, os falantes respeitam o princípio cooperativo de Grice e não somente cumprem a máxima de quantidade, como dão maior ênfase à máxima de relevância. 
Com um sintagma quantificado negativo na posição de objeto parece ocorrer a mesma operação:

(57) A: O João leu este livro?

B: O João não leu $\backslash N A D A_{F S}$.

Na sentença (57), imaginemos que João precisa ler vários livros para se preparar para o vestibular. Seus pais estão preocupados porque não o veem estudando. O pai de João, para incentivá-lo, compra um livro de leitura obrigatória para o vestibular. Só que está em dúvida se João já o leu, por isso faz a pergunta que está em B. Sabendo que o filho não está preocupado com as leituras, a mãe responde que "O João não leu nada", mostrando assim, que não foi só o livro em discussão que o João não leu, mas todos os livros de leitura obrigatória para o vestibular. Com tal resposta, a mãe de João, por estar chateada com tal situação, quer enfatizar que a propriedade negativa de não ler livros não se aplica somente ao livro comprado pelo pai, mas a todos os livros que João deveria ler. Para a mãe do João, então, é mais relevante responder completamente a uma super-questão implícita do tipo "Que livros o João leu?", do que simplesmente responder à questão dada. Com isso, a falante modifica a questão sob discussão e, para marcar tal estratégia, faz uso do acento de FS. O determinante negativo que recebe tal acento demonstra que ocorreu uma operação de alargamento de domínio, em que o elemento dado pelo discurso, no caso "o livro comprado pelo pai do João" insere no contexto todo o conjunto a que faz parte. Este, por sua vez, é enfatizado.

Os quantificadores negativos "ninguém" e "nada" parecem realizar operações parecidas com universal "todo" nos contextos anteriores, em que a resposta abrange não somente indivíduo dado pelo contexto, mas todo o conjunto do qual este indivíduo faz parte. Assim como no uso do quantificador universal, o falante, ao dar uma resposta sobreinformativa com um quantificador negativo, quer enfatizar que a propriedade em discussão não é exclusiva do elemento dado. Porém com o quantificador negativo, tenta amenizar ou mostrar sua frustração com a propriedade negativa em questão. A entonação tem as características de um acento de foco sobreinformativo (FS), já que o acento descendente recai sobre o quantificador e indica uma estratégia por parte do falante. O constituinte com acento de foco sobreinformativo realiza uma operação de alargamento de domínio a partir do constituinte dado.

As estratégias até aqui apresentadas têm uma característica em comum com as sentenças que apresentam o que Büring chama de tópico puramente implicacional. Nestas, o 
falante lança ao contexto questões a mais que acredita ser relevante para a conversação e as deixa sem resposta. Nos contextos apresentados nesta seção, o falante, além de lançar outras perguntas que não fazem parte do common ground, responde completamente a uma superquestão que domina a questão dada, e em consequência disso, responde automaticamente a todas as questões lançadas, ou seja, não deixa nenhuma das questões em aberto. Abaixo repetiremos o contexto que apresenta um tópico puramente implicacional.

(58) A: A sua esposa foi pra festa?

B: A / MINHA $_{C T}$ esposa $\backslash \mathrm{NÃO}_{F}$ foi pra festa.

Em (58), o falante ao responder com o acento de tópico sobre o constituinte "a minha esposa", além de responder ao que foi solicitado, lança implicitamente no contexto questões sobre demais esposas. Tal falante indica que está respondendo parcialmente a uma superquestão como: “Quem foi pra festa?”. A diferença deste exemplo de Büring para as respostas sobreinformativas, portanto, é que enquanto em contextos como (58), o falante indica que está respondendo parcialmente a uma super-questão e deixa as demais sub-questões em aberto, nas respostas sobreinformativas, o falante responde completamente à super-questão a qual a questão explícita está submetida. Com isso, o falante, ao mesmo tempo em que lança as perguntas, as responde, saturando qualquer tipo de pergunta relacionada àquele contexto.

Nesta seção foram discutidos contextos de perguntas polares com respostas sobreinformativas. Nas respostas, foram vistos casos com o quantificador universal "todo" e quantificadores negativos como "nenhum" e "nada". Em todas as sentenças, o falante utilizou-se de uma estratégia do discurso de responder além do esperado, pois nos contextos observados, julgou ser mais relevante responder a uma super-questão e não apenas à questão solicitada, uma vez que a propriedade inserida pela pergunta não era exaustiva em relação ao elemento, mas compartilhada por todo o conjunto. Desta forma, o falante deseja enfatizar a propriedade em questão, ou por ter uma carga positiva para o contexto, ou por ter uma carga negativa. Todas as respostas sobreinformativas mostraram-se estar de acordo com o princípio de congruência (Roberts (1996), Büring (2003)), pois estavam relacionadas com a questão sob discussão dada no contexto. Em todas as sentenças há um acento prosódico peculiar. Este acento recai sobre o determinante e apresenta uma curva descendente, o que indica que o falante está fazendo uso de uma estratégia: responder completamente a uma questão que domine a questão explicitada. A este tipo de marcação, chamamos de foco sobreinformativo (FS). O constituinte marcado por tal acento, de foco sobreinformativo, é diferente dos 
conceitos dados por outros autores (Zubizarreta (1998), Mioto (2003), Erteschik-Shir (2007)), já que em vez de negar o elemento dado no contexto, nega a exaustividade de certa propriedade em relação a este elemento. Além disso, os constituintes sobreinformativos desta seção demonstram que ocorre uma operação de alargamento de domínio de um constituinte dado no contexto para todo o seu conjunto. Esta operação é oposta a que ocorre nos casos de tópico restritivo de Erteschik-Shir (2007). Os determinantes do constituinte focalizado, que são marcados pelo acento de foco sobreinformativo, representam a informação nova da sentença, enquanto o NP do constituinte focalizado não apresenta curva entonacional, o que indica que tal informação já faz parte do common ground. Essa informação é comparada com os demais elementos do conjunto.

Em todas as respostas sobreinformativas, as máximas de Grice foram observadas e respeitadas, tanto as de quantidade e modo, que num primeiro momento pareciam ser infringidas, como em especial a de relevância e de qualidade. Na seção a seguir, veremos o que ocorre com contextos formados por perguntas de constituinte.

\subsubsection{Com perguntas de constituinte}

Os contextos que seguem são a partir de perguntas de constituinte, em que um elemento interrogativo (quem, quanto, o que, qual) é inserido na pergunta e geralmente é preenchido na resposta com um constituinte com função de foco.

(59) A: Que nota o João tirou?

B: \TODO $\mathrm{MUNDO}_{F S}$ tirou $\backslash 10 \mathrm{NA}$ PROVA $F$.

Em certa ocasião, os alunos fizeram uma prova na disciplina do professor Carlos. A professora Maria quer saber qual foi o desempenho de João na prova desta disciplina, já que ele não está indo bem na sua. Pergunta então o que está em A. Carlos, satisfeito com o desempenho de seus alunos na prova, responde que "TODO MUNDO tirou 10 NA PROVA". Ou seja, o João e toda a classe tiraram nota 10. Enfatizando que a propriedade de "tirar 10 na prova" se aplica a todos os seus alunos, Carlos quer demonstrar sua alegria e satisfação com eles. Com tal resposta, o falante fez uso da estratégia de resposta sobreinformativa e modificou a questão sob discussão, pois julgou ser mais relevante responder completamente a uma super-questão de (59)A do tipo: “Que nota os alunos tiraram na prova?”.

Os contextos de pergunta de constituinte com respostas sobreinformativas produzem resultados parecidos com os contextos anteriormente analisados, de perguntas polares. A 
resposta acarreta o que foi requerido e, além disso, traz informações a mais que são comuns a todos os membros de certo conjunto. Estas informações a mais são julgadas pelo falante relevantes para serem inseridas no contexto e por este motivo o falante resolve responder completamente a uma pergunta mais ampla. A árvore do discurso pode ser, então, representada como segue:

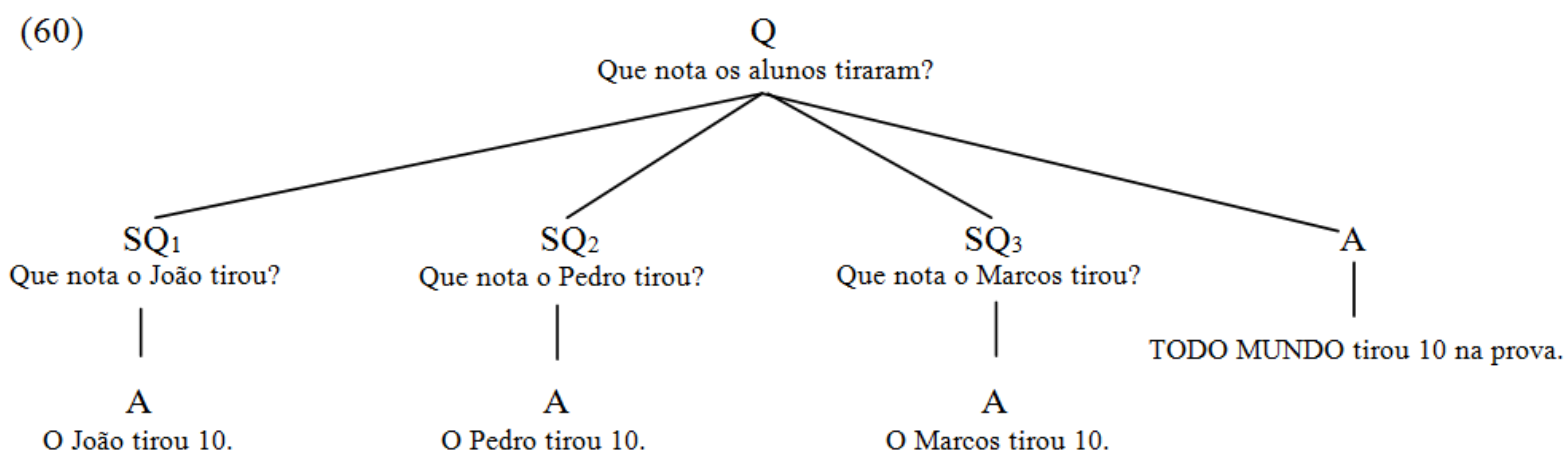

A estrutura da $d$-tree em (60) é similar à vista na seção anterior. Assim como em contextos com perguntas polares, o falante, ao utilizar a estratégia de uma resposta sobreinformativa, por responder completamente à super-questão que domina a questão explicitada no discurso, responde completamente às sub-questões que estão sob o domínio dessa super-questão, como ilustra a árvore do discurso acima.

A prosódia da sentença em (59) também é similar às demais até aqui estudadas. Ambas apresentam dois picos de acento prosódico com curva descendente. A diferença é que em contextos de perguntas polares um dos acentos recai sobre o verbo, para respostas afirmativas, ou sobre a negação para as negativas, enquanto o outro recai sobre o constituinte sobreinformativo. Já na sentença acima, um dos acentos claramente identifica um constituinte de foco informacional, pois recai sobre o constituinte que carrega a informação nova no contexto, enquanto outro recai sobre o constituinte quantificado. Este não pode ser um acento de CT de Büring, já que não apresenta uma curva ascendente. O acento que recai sobre o constituinte sobreinformativo o leva a assumir uma posição de evidência no contexto. Este constituinte, que apresenta um conjunto do qual o tópico inserido na pergunta faz parte, parece, então não receber a função de foco meramente informacional na sentença, mas de foco sobreinformativo. Tal acento identifica que o falante optou por utilizar a resposta sobreinformativa. Contextos como (59), então, apresentam dois constituintes que recebem acento de foco, sendo um F, de foco informacional e outro de FS, foco sobreinformativo. Estes, além de apresentarem acento de pico descendente, trazem novas informações ao 
contexto. O último, além destas características, também apresenta a função de indicar uma estratégia discursiva por parte do falante.

Nos contextos abaixo, com constituintes sobreinformativos em outras posições sintáticas, as mesmas características se repetem. O falante responde a uma super-questão da questão pronunciada porque julga ser mais relevante trazer informações sobre todo o conjunto no qual o elemento de tópico está inserido, com isso responde completamente qualquer outra pergunta relacionada à propriedade em questão. A super-questão implícita a qual o falante responde completamente está indicada abaixo da questão explícita, entre parênteses. No que diz respeito à prosódia, apresentam dois acentos de curva descendente, um de foco informacional $(\mathrm{F})$, que recai sobre o constituinte requerido pela questão e outro de foco sobreinformativo (FS), que recai sobre o constituinte sobreinformativo. Este demonstra o uso de uma estratégia no discurso, assim como a ocorrência de uma operação de alargamento de domínio a partir do constituinte dado pelo contexto.

(61) A: Quem orientou a Maria?

(Quem orientou os alunos?)

B: \O JOÃO $F$ orientou \TODOS OS ALUNOS DE INICIAÇÃO $F S$.

(62) A: Quem enviou o convite pra MARIA?

(Quem enviou o convite para os professores?)

B: $\backslash \mathrm{O}$ JOÃO ${ }_{F}$ enviou o convite pra $\backslash$ TODOS OS PROFESSORES ${ }_{F S}$.

(63) A: Onde o João comprou o livro de linguística?

(Onde o João comprou seus livros?)

B: O João comprou $\backslash$ TODOS OS LIVROS $F S$ na $\backslash$ SARAIVA $_{F}$.

Ao fazer uso de uma resposta sobreinformativa, nos contextos acima, o falante quis enfatizar a propriedade em discussão e por algum motivo peculiar, como demonstrar satisfação em relação à propriedade, resolve responder completamente a perguntas mais amplas. Com isso há um contraste em relação à não-exaustividade da propriedade em discussão, que pertence a todos os componentes do conjunto e não apenas ao elemento dado.

O uso de QPs negativos também é adequado para respostas sobreinformativas em contextos de perguntas de constituinte. Observe o diálogo abaixo, com constituintes negativos nas posições de sujeito e objeto. 
(64) A: Que livro o João leu?

B: $\backslash$ NINGUÉM $F S$ leu $\backslash$ NADA $_{F}$.

Em certa ocasião, a professora de literatura determinou aos alunos que lessem pelo menos um livro de Machado de Assis. Maria, professora de inglês, ficou curiosa pra saber que livro o João escolheu, já que ele não gosta de ler. Pergunta, então, o que está em (64). A professora, decepcionada com a falta de interesse dos alunos, ao dar a resposta em B, responde completamente a uma super-questão implícita como "Que livro os alunos leram?". Não foi somente o João que deixou de cumprir sua determinação, mas toda a classe. A estratégia, como as demais desta subseção, apresenta dois picos de acento com curva descendente. Um de foco informacional, que recai sobre a informação requerida pela questão e outro de foco sobreinformativo, que recai sobre o determinante do constituinte sobreinformativo. $\mathrm{O}$ acento de FS indica que o falante fez uso da estratégia do discurso de responder completamente a uma questão que domina a questão dada. Além disso, tal marcação realizou uma operação de alargamento de domínio a partir do elemento dado no discurso, o livro "Dom Casmurro", para o conjunto a que este elemento faz parte "todos os livros de Machado de Assis”.

Nesta seção foram observadas estratégias de respostas sobreinformativas com perguntas de constituinte, em que há um elemento interrogativo na pergunta que geralmente é substituído pelo foco da sentença. Tais estratégias apresentam características semântico/pragmáticas semelhantes às demais. A resposta dada representa uma resposta completa para uma super-questão que acarreta a questão sob discussão e traz informações além, que são comuns a todos os elementos de determinado conjunto. O falante a pronuncia por julgar ser mais relevante já trazer todas estas informações para o contexto, pois deseja enfatizar a propriedade em discussão. Tal estratégia apresenta a característica de lançar mais perguntas ao contexto, como nos tópicos puramente implicacionais, no entanto, essas perguntas são todas respondidas. Com relação à prosódia, todas as sentenças apresentam dois picos de acento de curvatura descendente, sendo que um é de F e outro de FS. A marcação de foco sobreinformativo, além de indicar uma estratégia de discurso, realiza uma operação de alargamento de domínio, em que o elemento dado no discurso insere todo o conjunto a que faz parte. Tal conjunto é focalizado no contexto. Mais uma vez todas as máximas de conversação de Grice, direta ou indiretamente, foram respeitadas. 


\subsubsection{Com perguntas implícitas}

Há outras construções na língua, em que não há necessariamente uma pergunta explícita no contexto, mas que também levam o falante a utilizar expressões sobreinformativas. Essas expressões geralmente vêm contrastar ou complementar uma declaração dada anteriormente no contexto. Vejamos um exemplo, abaixo:

(65) A: O partido do João é corrupto.

B: \TODO $F S$ PARTIDO POLÍTICO é corrupto.

A construção acima possui as mesmas características identificadas nas anteriores, em que há uma pergunta explícita. A única diferença é que no contexto com uma pergunta explícita, o falante, ao dar uma resposta sobreinformativa, responde ao perguntado, além de responder sobre os demais elementos do conjunto. Fica implícito algo do tipo "foi, mas não foi só ele". No contexto acima, o falante B aceita a declaração dada por A e esta informação passa a fazer parte do common ground. Então, declara que "TODO PARTIDO POLÍTICO é corrupto". É como se uma expressão como: “além do João" ficasse implícita antes da sentença B.

Em um contexto em que dois amigos estão conversando sobre política, o falante A declara que o partido de João é corrupto. O falante B, pra deixar claro que esta propriedade de ser corrupto, segundo seu julgamento, é de todo partido político e não exclusivamente do partido de João, responde que "TODO PARTIDO POLÍTICO é corrupto". O falante B responde completamente a uma questão implícita mais ampla. A resposta acarreta que o partido de João é corrupto, mas de certa forma ameniza a afirmação do falante. O determinante quantificado recebe o acento com curva descendente de foco sobreinformativo (FS) igual ao acento nas estratégias anteriormente observadas. A marcação de FS no determinante "Todo" também indica que ocorreu uma operação de alargamento de domínio aos elementos do conjunto de "partidos políticos". A partir do constituinte de tópico "o partido de João", todo o conjunto a que este elemento faz parte é focalizado na sentença. Vejamos a d-tree do contexto acima: 


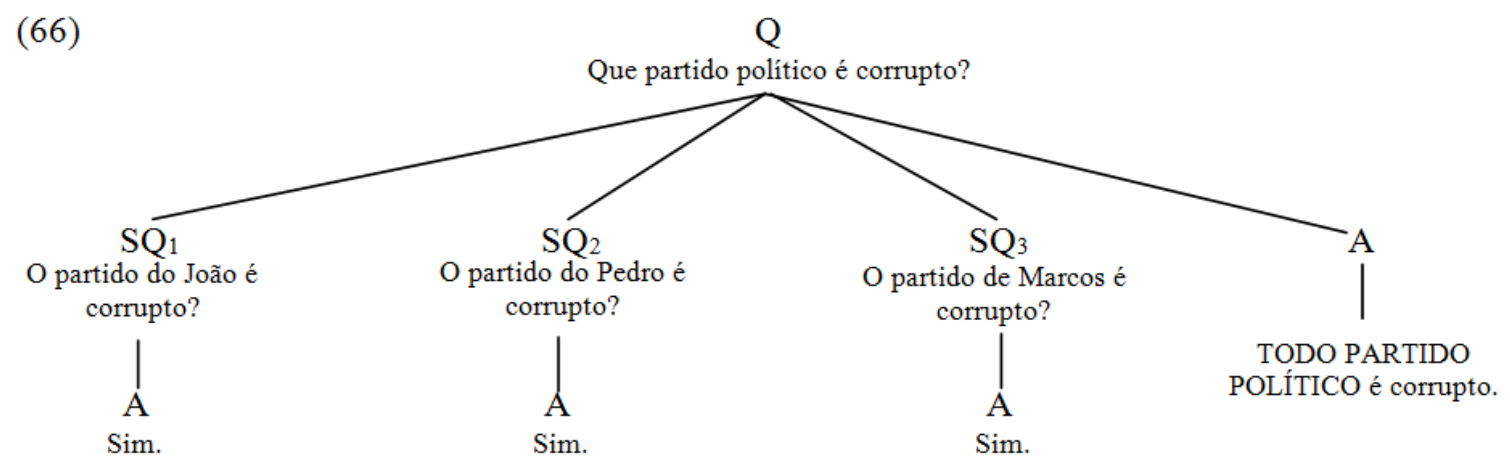

$\mathrm{Na}$ estrutura hierárquica da $d$-tree apresentada acima, como não há uma pergunta explícita, pressupomos que as questões sob discussão sejam dos tipos acima. Podemos, então, observar que a declaração do falante em (67)B representa uma resposta completa para uma questão como Q, o que acarreta respostas para as sub-questões de Q. Tal estratégia demonstra que o falante ao declarar B, quer deixar clara a não-exaustividade de ser corrupto em relação ao partido do João.

O mesmo fenômeno parece ocorrer nos contextos abaixo, em que o primeiro apresenta o constituinte quantificado na posição de objeto e o segundo apresenta um sintagma negativo:

(67) A: Os índices de violência têm aumentado em São Paulo.

B: Os índices de violência têm aumentado em $\backslash$ TODAS $_{F S}$ AS GRANDES CIDADES.

(68) A: O João ainda não entregou seu trabalho.

B: \NINGUÉM ${ }_{F S}$ entregou o trabalho.

Em ambas as construções parece que o falante $B$, ao afirmar a sentença sobreinformativa, pretende de certa forma amenizar a gravidade da afirmação anterior. Em (67), o falante B deseja mostrar que os altos índices de violência não são exclusividade de São Paulo, talvez porque seja um amante da cidade e de seu governo, deseja defendê-la e por isso se utiliza da estratégia de responder completamente a uma questão implícita do tipo: "Em que cidades os índices de violência têm aumentado?”. Em (68), o falante B utiliza a estratégia de responder completamente a uma questão implícita do tipo "Quem entregou o trabalho". Com isto, de certa forma, ele defende o João, já que não foi apenas ele que não entregou o trabalho, mas ninguém das pessoas salientes no contexto. Em ambas, ocorre o processo de alargamento 
de domínio para focalização de todo o conjunto a que o elemento dado na questão faz parte. Ainda, o acento prosódico se repete como acento descendente de foco sobreinformativo e assim como em todos os contextos vistos, o princípio cooperativo de Grice e suas quatro máximas de conversação são respeitados.

Nesta seção, vimos estratégias de respostas sobreinformativas em contextos de perguntas implícitas. Tais estratégias apresentam as mesmas características semânticopragmáticas das anteriores, em que o falante, ao julgar outra questão relevante para o contexto, responde completamente a uma super-questão da questão em discussão. No entanto, a asserção dada faz parte do common ground e a resposta sobreinformativa apenas contrasta a não exaustividade da propriedade em relação ao elemento dado já aceito no common ground. Ainda, possuem uma implicatura de que o falante deseja amenizar a afirmação anterior, geralmente com carga negativa, numa espécie de contraste ou complementação desta. As sentenças possuem um pico de acento que recai sobre o determinante quantificado. Este, por ter curva descendente e identificar uma estratégia no discurso é identificado como de foco sobreinformativo (FS). Tal marcação indica um processo complexo de focalização, em que a partir do constituinte de tópico dado na sentença, todo o conjunto a que este elemento faz parte é focalizado. Além disso, a marcação de foco sobreinformativo indica o uso de uma estratégia discursiva por parte do falante.

\subsection{ESTRATÉGIAS DE RESPOSTA SOBREINFORMATIVA E INVERSÃO DE ESCOPO}

Retomando a sentença analisada no capítulo anterior, podemos perceber a ocorrência do mesmo fenômeno nos contextos com respostas sobreinformativas apresentados até aqui: o falante, ao contrastar a afirmação anteriormente discursada, deseja mostrar que a propriedade em questão não é exclusiva do indivíduo dado, mas de todo o conjunto a que tal indivíduo faz parte. Repetimos o contexto abaixo:

(69) A: Estou chateado! Mais de dois alunos reclamaram da minha palestra;

B: Não é nada pessoal. Mais de dois alunos reclamaram de TODA $F S$ PALESTRA DO CONGRESSO.

O contexto dado para a sentença acima é de que dois professores que participaram de 
determinado congresso estão conversando e um deles, o professor A, diz ao outro: Estou chateado porque mais de dois alunos reclamaram da minha palestra. $\mathrm{O}$ outro, professor $\mathrm{B}$, na tentativa de consolá-lo afirma: "não é nada pessoal, porque mais de dois alunos reclamaram de TODA PALESTRA DO CONGRESSO". Neste contexto, o professor B, ao dar tal informação, como forma de amenizar a situação, acredita que seja relevante, mostrar para o professor A que a propriedade de "mais de dois alunos reclamar de x" não é exclusiva da palestra dele e sim de "todas as palestras do congresso". Faz uso, então da estratégia de responder completamente a uma questão implícita como: "Mais de dois alunos reclamaram de que palestras?". Tal estratégia pode ser representada na árvore do discurso ( $d$-tree) abaixo. Consideremos que o professor A seja João e os demais professores no contexto sejam Pedro e Marcos.

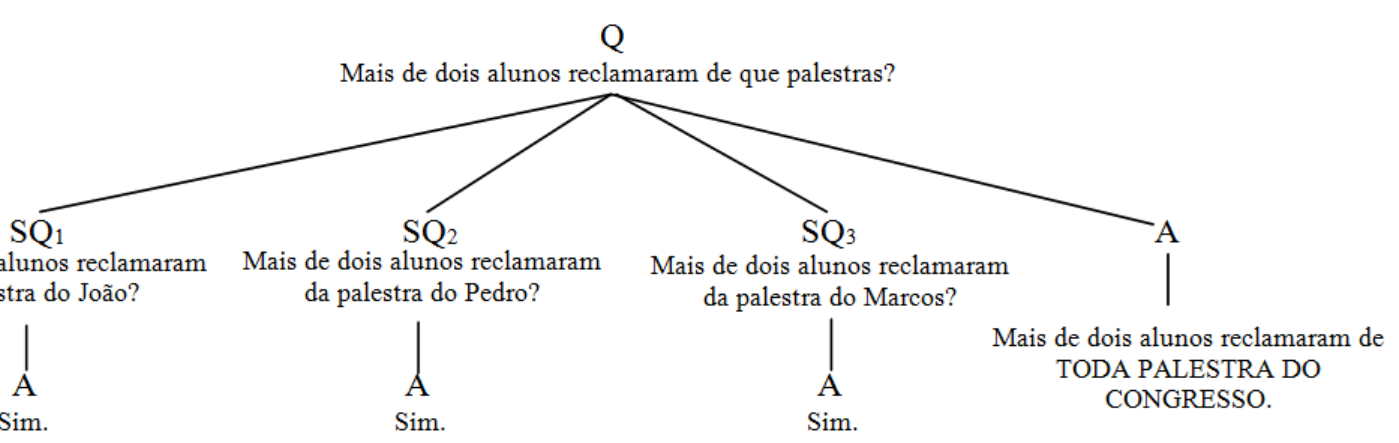

A d-tree acima nos mostra que o falante, ao declarar "Mais de dois alunos reclamaram de TODA PALESTRA DO CONGRESSO", faz uso de uma estratégia do discurso de responder completamente à pergunta implícita Q. Desta maneira, responde também, às sub-questões de $\mathrm{Q}$, que são acarretadas pela super-questão. Declarando tal resposta, o falante, para amenizar a propriedade negativa que recai sobre a palestra do professor João, quer deixar claro que a propriedade de "mais de dois alunos reclamarem de palestra" não é exclusiva para a palestra desse professor, mas para todos os elementos contidos neste conjunto, no caso, "palestras do congresso".

O constituinte "toda palestra do congresso" recebe um acento de FS, o que indica a estratégia utilizada pelo falante e demonstra que ocorreu um processo complexo de focalização, em que a partir do constituinte de tópico, ocorre um alargamento de domínio. Todo o conjunto a que este constituinte pertence, então, é destacado no contexto e recebe a função discursiva de foco.

Essas características semânticas e pragmáticas presentes no contexto, além do acento 
entonacional descendente no determinante, que caracteriza o constituinte "toda palestra do congresso" como foco sobreinformativo, parecem ser essenciais para a inversão de escopo que, como vimos, ocorre em sentenças deste tipo. Retornaremos ao fenômeno de inversão de escopo no próximo capítulo, levando em conta todas as características semânticas, pragmáticas e prosódicas vistas neste capítulo.

\subsection{RESUMO DO CAPÍTULO}

Neste capítulo, apresentamos um fenômeno muito recorrente na língua, a que denominamos de respostas sobreinformativas. A partir dos contextos aqui analisados, podemos perceber que em sentenças com respostas sobreinformativas, o determinante que introduz a super-informação apresenta um acento entonacional descendente. Propomos que tal acento, por indicar uma estratégia de discurso por parte do falante e trazer uma informação nova ao contexto, seja um acento de foco sobreinformativo. Com isso, diferentemente de Büring (2003), defendemos a estrutura de marcações entonacionais de sentenças, além de apresentar acento de foco (F), tópico contrastivo (CT), também pode apresentar uma marcação prosódica de foco sobreinformativo. Propomos, ainda, que ocorre um processo de focalização complexo em sentenças com constituintes que apresentam acento de foco sobreinformativo. Neste processo, o determinante do constituinte que recebe tal acento realiza um alargamento de domínio a partir do elemento com função de tópico e com isso, todo o conjunto a que tal elemento faz parte é evidenciado no contexto.

Em todos os casos vistos aqui, a declaração sobreinformativa responde completamente a uma super-questão que domina a questão sob discussão. Portanto, tal resposta acarreta a resposta requerida e traz informações a mais, relacionadas a todo o conjunto no qual o elemento de tópico está inserido. O uso da estratégia sobreinformativa faz parte de um contexto em que o falante julga mais relevante dar informações sobre todos os elementos do que apenas ao requerido, já que tal informação não é exclusiva para tal elemento. Por este motivo muda a questão sob discussão no discurso, respondendo a uma super-questão da pergunta presente no contexto.

Podemos perceber que todas as sentenças respeitam as quatro máximas conversacionais de Grice, sobretudo à de relevância. Para o falante que responde à questão com um constituinte sobreinformativo, o elemento inserido pelo tópico não é exaustivo em relação à propriedade que está em discussão. Há outros elementos, aliás, todos do conjunto do 
qual o elemento de tópico faz parte, que compartilham da mesma propriedade. Isto, conforme o julgamento do falante é relevante para trazer ao contexto. As implicaturas geradas por essa estratégia vão variar conforme o contexto. Em contextos em que há uma propriedade positiva em discussão, o falante deseja enfatizar tal propriedade. Em contextos em que o que está em jogo é uma propriedade negativa, como nos casos da seção de perguntas implícitas ou mesmo das sentenças que objetivam este estudo, o falante faz uso da estratégia de sobreinformação como forma de amenizar a carga negativa que a propriedade em discussão tem. Com isso, deseja mostrar que esta não é exclusividade do indivíduo em pauta, mas de todo o conjunto a qual ele faz parte. Ou seja, falante contrasta a não exaustividade da propriedade em discussão em relação ao elemento dado.

Em estratégias a partir de perguntas polares e de constituinte, há dois picos de acento com curva descendente, um no determinante do constituinte sobreinformativo, foco sobreinformativo (FS), e outro sobre o constituinte que introduz a informação requerida, foco informacional (F). Contextos que não apresentam perguntas explícitas, como é caso das sentenças que são objeto deste estudo, também possuem este tipo de foco que introduz um constituinte sobreinformativo e apresenta um acento de FS. A marcação de foco sobreinformativo (FS) e não foco meramente informacional (F) indica que há uma estratégia discursiva da parte do falante. Estes contextos têm uma diferença dos demais, com perguntas explícitas, pois aceitam uma declaração dada e a partir de então, com o intuito de enfatizar a não-exaustividade de certa propriedade em relação a um elemento, fazem uso da estratégia sobreinformativa.

Quando o constituinte na posição de objeto recebe a marcação de FS, parece que tal marcação facilita a inversão de escopo. No próximo capítulo, observaremos como a marcação de foco sobreinformativo pode interferir na inversão de escopo de sentenças quantificadas do PB e se todos os tipos de sintagmas quantificados são sensíveis à marcação deste tipo específico de foco. 
CAPÍtULO 3

FOCO SOBREINFORMATIVO E INVERSÃO DE ESCOPO

\subsection{INTRODUÇÃO}

Até agora analisamos a possibilidade de inversão de escopo em contextos de resposta sobreinformativa em apenas uma sentença com dois sintagmas quantificados, um CQP "mais de dois alunos" na posição de sujeito e um DQP "toda palestra do congresso" na posição de objeto. Neste capítulo, observaremos se este fenômeno pode ocorrer com outros tipos de sintagmas quantificados tanto na posição de sujeito como de objeto. Primeiramente, olharemos para sentenças com o GQP "dois alunos" na posição de sujeito interagindo com os diversos tipos de sintagmas quantificados na posição de objeto. Em seguida, observaremos se o GQP "alguns" permite ou não inversão de escopo em interação com diversos tipos de sintagmas quantificados. Por fim, veremos como o DQP distributivo "todo" interage com outros quantificadores e se estes são sensíveis ou não ao contexto para permitirem inversão de escopo.

\subsection{ANÁLISE DOS DADOS}

\subsubsection{Sintagmas quantificados cardinais}

Vejamos se em uma sentença com um quantificador cardinal na posição de sujeito, como "dois alunos" também podemos obter inversão de escopo em um contexto marcado por foco sobreinformativo:

(1) Dois alunos reclamaram de toda palestra do congresso.

A sentença (1), em um contexto neutro, em que a pergunta implícita ou explícita que a introduz seja do tipo “o que aconteceu?”, tem uma leitura mais saliente, senão a única, de escopo linear, em que dois alunos foram responsáveis por reclamar de todas as palestras do congresso. A formalização correspondente a essa leitura é representada em (2) e sua estrutura sintática em (3). 
(2) $\mid\{$ y: y é aluno $\} \cap\{$ y: $\forall \mathrm{x}: \mathrm{x}$ é palestra do congresso $\rightarrow[\mathrm{y}$ reclamou de $\mathrm{x}]\} \mid=2$

Paráfrase: $O$ número de alunos que reclamou de todas as palestras do congresso é maior que dois.

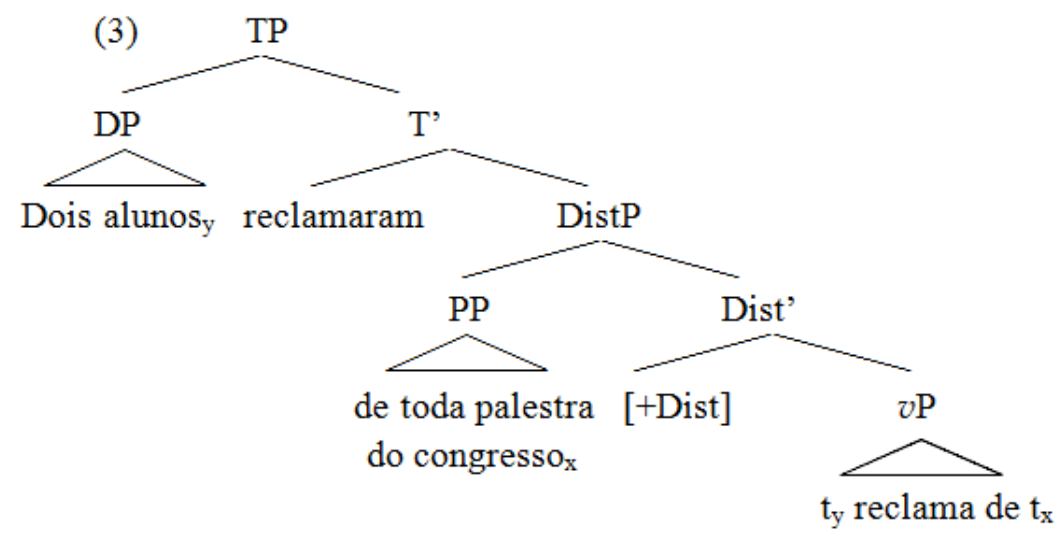

Porém, se em um contexto, um professor comenta com o outro: estou chateado porque dois alunos reclamaram da minha palestra. O outro para consolá-lo e deixar claro que a propriedade de "dois alunos reclamar de x" não é exclusiva de sua palestra, faz uso da estratégia discursiva de uma resposta sobreinformativa e responde:

(4) Não se preocupe porque dois alunos reclamaram de TODA $F C$ PALESTRA DO 'CONGRESSO.

Com o uso desta estratégia por parte do falante, que prefere responder a uma superquestão implícita do tipo: "Mais de dois alunos reclamaram de quantas palestras?", temos uma leitura de escopo inverso, em que para cada palestra do congresso, há dois alunos que reclamaram. Ressaltamos que consideramos a questão implícita nos exemplos do capítulo anterior, como uma questão relacionada a indivíduos: "Quem foi pra festa?", "Mais de dois alunos reclamaram de que palestras?". Daqui em diante assumiremos que a questão implícita está relacionada com a quantidade de elementos do contexto, isto porque as sub-questões que são dominadas pela questão sob discussão formam uma escala de quantidade com os quantificadores: "um", "alguns", "a maioria", "todo", conceito que será importante nos exemplos posteriores. Veremos com mais detalhes esta estrutura de árvore mais adiante.

Alguns falantes do PB não aceitam tal leitura e mesmo em contextos marcados por 
foco aceitam somente a leitura de escopo linear. Uma possível explicação para essas diferenças de interpretação entre os falantes é que, como já afirmado por Negrão (1999), sintagmas cardinais em PB podem ser considerados como denotadores de grupo ou sintagmas de contagem. Se o falante interpreta o QP "dois alunos" como um sintagma de contagem (CQP), há a possibilidade de inversão de escopo. Se ao contrário, a leitura é de que o sintagma "dois alunos" é um denotador de grupo (GQP), a única interpretação será de escopo linear. Primeiramente, vejamos como fica interpretação do sintagma quantificado cardinal como um sintagma de contagem, que pode apresentar leitura de escopo invertido. Vejamos abaixo a representação formal para tal leitura:

(5) $\forall \mathrm{x}$ : x é palestra do congresso $\rightarrow \mid\{\mathrm{y}: \mathrm{y}$ é aluno $\} \cap\{\mathrm{y}:[\mathrm{y}$ reclamou de $\mathrm{x}]\} \mid=2$

Paráfrase: Para cada palestra do congresso $x$, o número de alunos que reclamou da palestra é maior que dois.

Da mesma forma que um CQP com um cardinal modificado, um sintagma cardinal do tipo "dois alunos" permite a inversão de escopo, desde que haja um contexto marcado por foco sobreinformativo em uma situação similar aos exemplos de respostas sobreinformativas. A representação da estrutura sintática para escopo invertido segue abaixo, em (6):

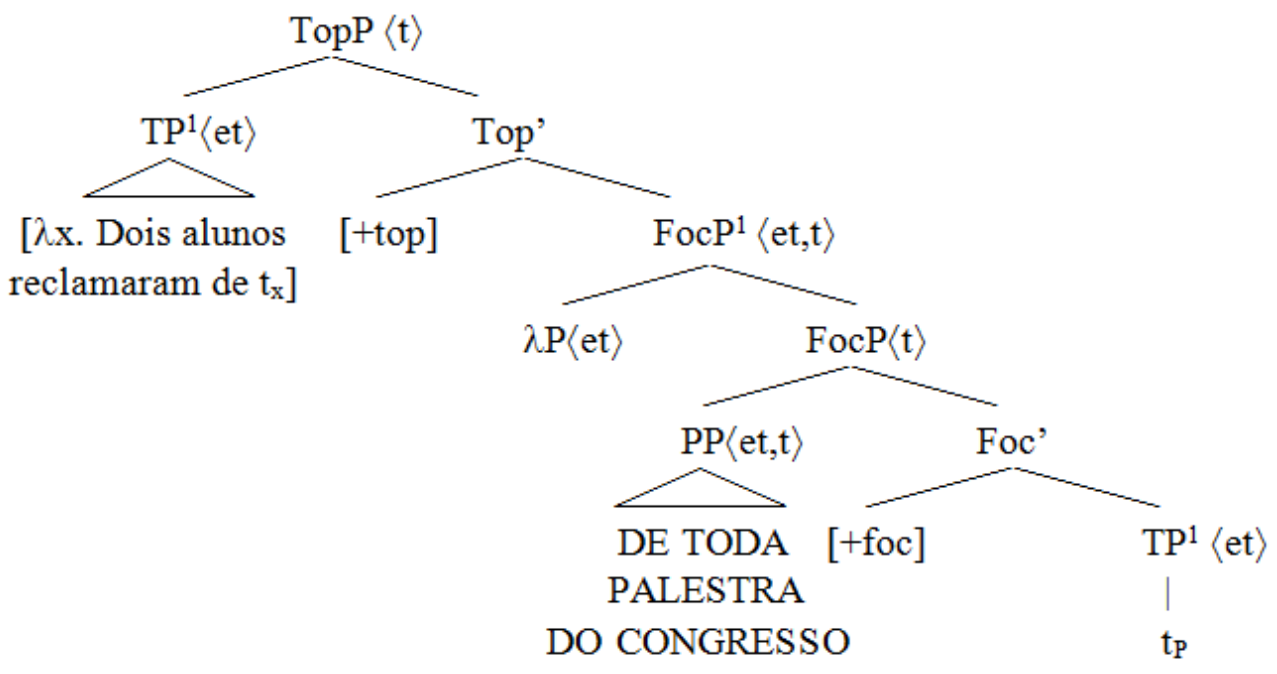

Com relação à estrutura acima, $\mathrm{TP}^{1}$ se move para a posição de Spec de TopP, deixando um vestígio do tipo $\langle$ et $\rangle$. O PP na posição de objeto, que possui um traço de foco, se move para a posição de Spec de FocP na periferia esquerda da sentença, a fim de checar seu traço $[+$ foc]. Fazendo a derivação semântica passo a passo, veremos que o resultado 
corresponde à formalização dada em (5). A estrutura sintática apresentada acima, então, mantém a ordem da sintaxe aberta, porém resulta em uma composição semântica correspondente à leitura de escopo inverso. Tal leitura é possível a partir de um contexto em que o falante faz uso da estratégia de resposta sobreinformativa para amenizar a propriedade negativa recaída sobre a palestra do professor em questão e mostrar que tal propriedade não é exaustiva em relação ao elemento dado. Para tal leitura, considerando a proposta de Büring (2003), temos a seguinte árvore do discurso:

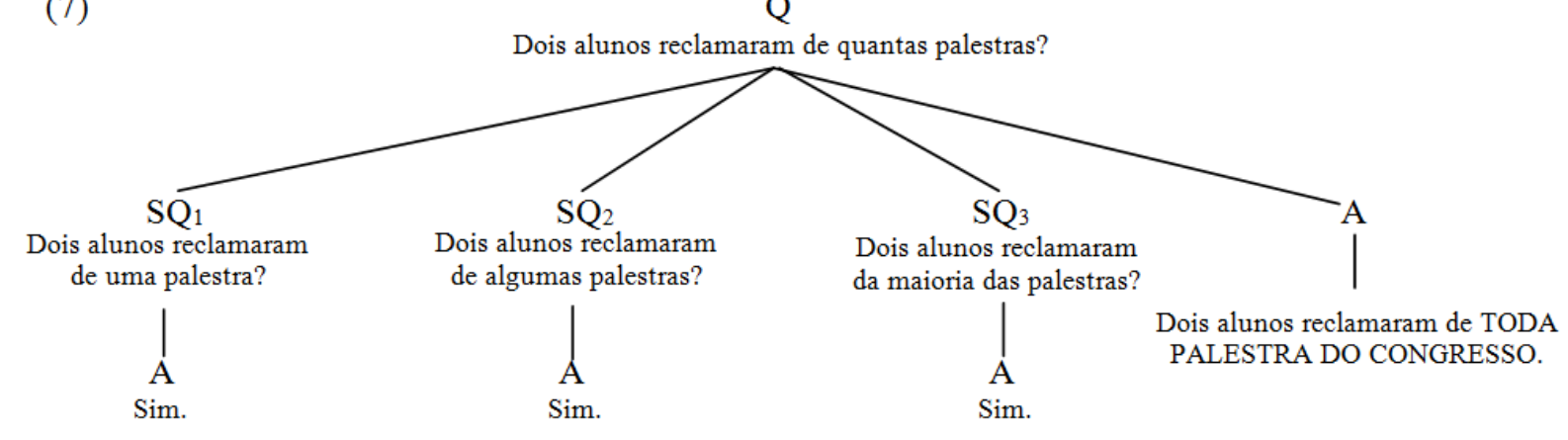

Conforme vimos anteriormente e podemos observar na $d$-tree acima, ao declarar que “dois alunos reclamaram de TODA PALESTRA DO CONGRESSO", o falante responde completamente à super-questão $\mathrm{Q}$. Com isso, as sub-questões que $\mathrm{Q}$ domina são respondidas também. Como as sub-questões fazem parte de uma escala, na qual o ponto mais alto desta escala corresponde a todos os elementos do conjunto, ao fazer tal declaração, o falante marca o determinante "TODA" com um acento de foco sobreinformativo (FS), que indica que ele está se referindo ao ponto mais alto da escala. Com isso, ocorre uma operação complexa de focalização, em que há um alargamento de domínio a partir do elemento com função de tópico no discurso. Todo o conjunto a que este elemento faz parte, então passa a ser destacado no discurso e recebe marcação de foco sobreinformativo. Esta marcação indica que o constituinte está em uma posição acima de TP, na periferia esquerda da sentença. Desta forma, temos a leitura de escopo invertido para a sentença (1).

Entretanto, mesmo em um contexto de foco sobreinformativo, alguns falantes aceitam somente a leitura de escopo linear em que o QP "dois alunos" na posição de sujeito tenha escopo sobre o QP "toda palestra do congresso" na posição de objeto. O bloqueio da inversão de escopo pode estar relacionado à estrutura sintática. Negrão (1999) afirma que sintagmas cardinais em PB podem ser interpretados tanto como CQPs, sintagmas de contagem, quanto como GQPs, denotadores de grupo. Ainda, autora defende que GQPs na 
posição de sujeito sempre ocuparão a posição de sujeito da predicação. Essa posição, segundo a estrutura hierárquica para os QPs proposta por Beghelli e Stowell (1997), é representada por Spec de RefP (pode também ser considerada como TopP) e encontra-se fora do domínio de CP. Neste caso, se o falante der ao sintagma quantificado "dois alunos"a interpretação de um denotador de grupo, então, mesmo em contextos marcados por foco sobreinformativo, a leitura que permanece é a de escopo linear. Voltemos à sentença com o sintagma quantificado “dois alunos" na posição de sujeito, desta vez assumindo a interpretação de um GQP.

(8) A: Estou chateado porque: Dois alunos reclamaram de toda palestra do congresso.

B: Não se preocupe porque dois alunos $_{[+ \text {ref. grupo] }}$ reclamaram de $\operatorname{TODA}_{F S}$ PALESTRA DO CONGRESSO.

Se no contexto acima, o falante interpretar o DP "dois alunos" como um denotador de grupo, este vai se mover para a posição de Spec de TopP, por ter um traço [+ referência de grupo] que indica que se refere um conjunto específico. Este movimento impedirá uma leitura de escopo inverso, mesmo com o QP na posição de objeto tendo uma marcação de foco sobreinformativo. A estrutura sintática para (8)B, então, será como segue:

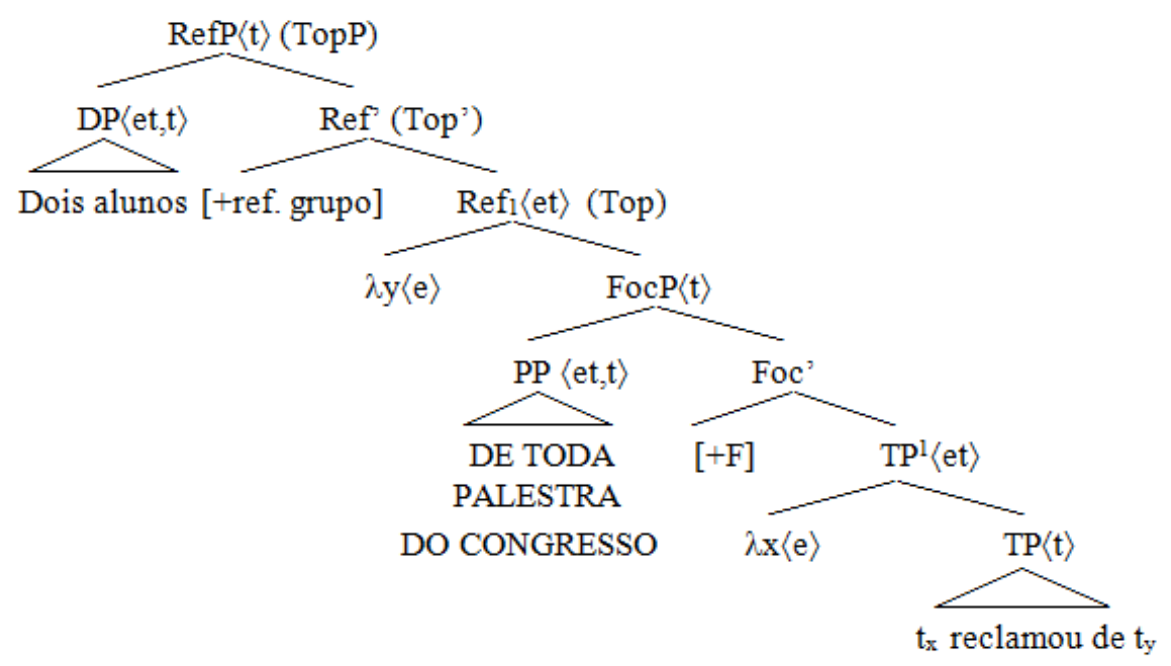

Na estrutura dada acima, o QP na posição de objeto "DE TODA PALESTRA DO CONGRESSO", que tem um traço de foco sobreinformativo, move-se para a posição de Spec de FocP. O QP na posição de sujeito "dois alunos", por sua vez, por ter um traço [+ ref. de grupo] pra checar, desloca-se para a posição de Spec de RefP. Tal posição, por estar fora do domínio de CP, c-comanda FocP. Desta maneira, mesmo com o QP na posição de objeto 
tendo uma marcação de foco sobreinformativo, a leitura de escopo invertido não é possível.

Vejamos se com outro tipo de quantificador ocupar a posição de objeto, ainda é possível haver inversão de escopo. A sentença abaixo, em (10), em um contexto neutro tem a leitura de que mais de dois alunos foram os responsáveis pela reclamação de dez palestras. Esta leitura tem a representação formal representada em (11).

(10) Mais de dois alunos reclamaram de dez palestras do congresso.

(11) $\mid\{\mathrm{y}: \mathrm{y}$ é aluno $\} \cap \mid\{\mathrm{y}:\{\mathrm{x}: \mathrm{x}$ é palestra $\} \cap\{\mathrm{x}:[\mathrm{y}$ reclamou de $\mathrm{x}]\}|=10|>2$

Paráfrase: Uma quantidade de alunos, maior do que dois, reclamou de dez palestras do congresso.

Pensemos, então, em um contexto parecido com os até aqui criados, em que haja uma marcação de foco sobreinformativo no constituinte que ocupa a posição de objeto. Dois professores estão conversando sobre certo congresso do qual participaram:

(12) A: Mais de dois alunos reclamaram da minha palestra.

B: Não se preocupe, pois não é nada pessoal, mais de dois alunos reclamaram de DEZ $_{F S}$ PALESTRAS DO CONGRESSO.

Desta forma, para cada uma das dez palestras há uma quantidade de alunos maior que dois que reclamou. Esta leitura é representada mais formalmente abaixo:

(13) $\mid\{\mathrm{x}: \mathrm{x}$ é palestra $\} \cap\{\mathrm{x}: \mid\{\mathrm{y}: \mathrm{y}$ é aluno $\} \cap\{\mathrm{y}:[\mathrm{y}$ reclamou de $\mathrm{x}]\}|>2|=10$

Paráfrase: Para cada uma das dez palestras, o número de alunos que reclamou é maior do que dois.

Da mesma forma que nos contextos anteriores, neste caso, também é possível uma leitura de escopo invertido quando há um CQP sintagma quantificado cardinal na posição de objeto interagindo com outro CQP, um cardinal modificado na posição de sujeito. Isto porque, no contexto dado, o falante, na tentativa de consolar o professor e mostrar que a propriedade de "mais de dois alunos reclamar de palestra" não é exclusiva para sua palestra declara que "mais de dois alunos reclamaram de DEZ PALESTRAS DO CONGRESSO" Com isso, se utiliza da estratégia de responder a uma questão implícita mais ampla. Nesse caso, no entanto, diferentemente dos exemplos com os QPs “todo" ou "nenhum” na posição de objeto, o falante 
não declara que a propriedade "mais de dois alunos reclamar" se aplica a todo o conjunto de palestras, mas sim a um número significativo delas. Ao responder tal questão, o falante responde a todas as sub-questões dominadas por ela. Vejamos a árvore do discurso que a representa:

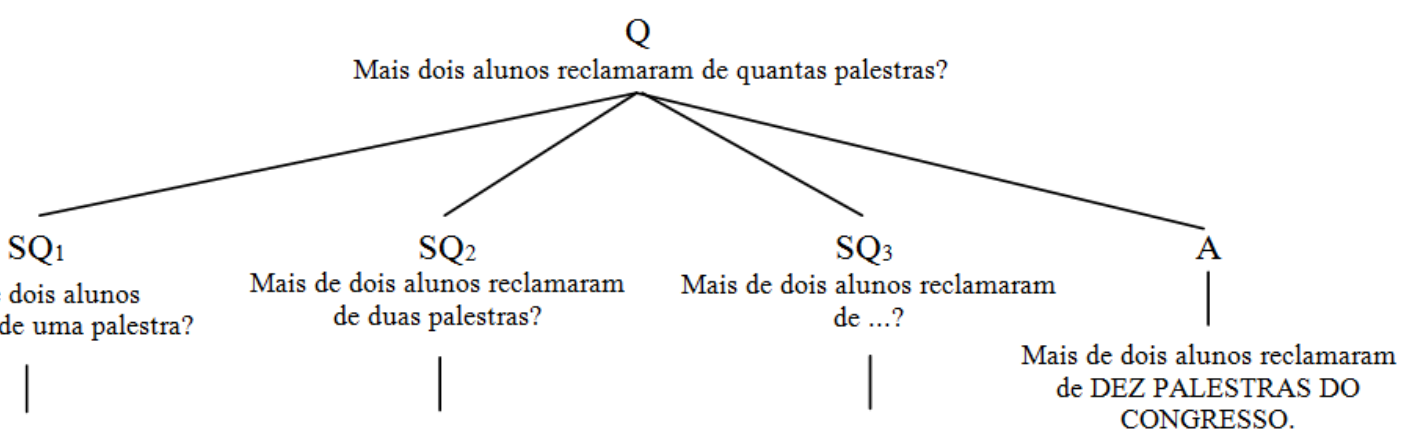

A

A

A

CONGRESSO.

Não. Não. Não.

Na $d$-tree acima, as sub-questões são relacionadas à cardinalidade dos elementos em discussão, no caso acima, "as palestras". Isto porque a resposta dada refere-se à quantidade de palestras que foram alvo da reclamação de mais de dois alunos. Ainda, por se tratar da cardinalidade e como a interpretação dada aos numerais nesta pesquisa é de que são exaustivos, a resposta para cada sub-questão é negativa. Vale lembrar também que logicamente a resposta "Mais de dois alunos reclamaram DEZ PALESTRAS DO CONGRESSO.” não acarreta que a palestra do professor A foi alvo de reclamação, em (12), já que as dez palestras em questão não necessariamente devem incluir a palestra em discussão. No entanto, como o professor A já havia inserido no common ground a informação de que tal palestra foi alvo da reclamação de mais de dois alunos, o falante B, ao proferir o enunciado, já havia aceitado tal asserção. Neste exemplo podemos ver que a resposta não necessariamente precisa ser relacionada a todos os indivíduos de certo conjunto, e responder completamente à super-questão, mas sim se referir uma quantidade relevante de elementos, tal que a resposta à determinada sub-questão acarrete outras sub-questões.

Assim como as demais estruturas sintáticas vistas até aqui, a estrutura abaixo mantém a estrutura aberta da sentença, além de contemplar a composição semântica para uma leitura de escopo inverso. 


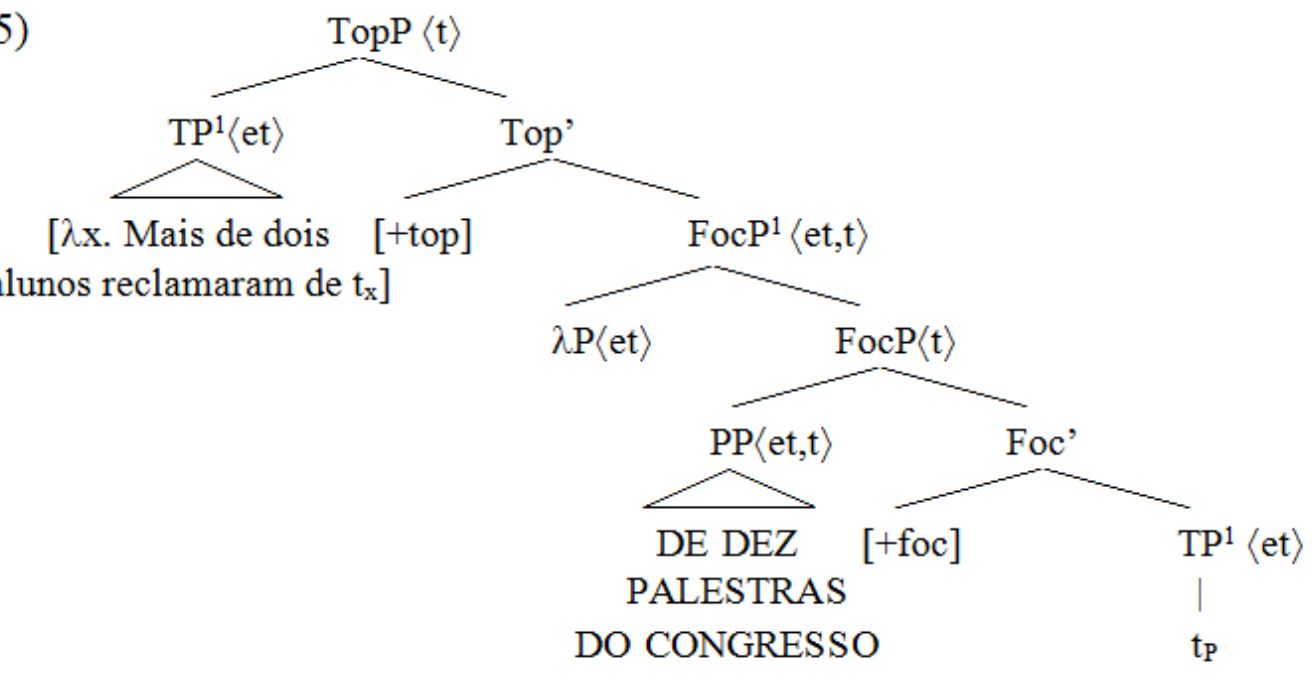

Observemos agora uma sentença com um GQP existencial como "alguns" na posição de objeto. Veremos tal sentença tanto em contexto neutro, quanto em um contexto em que haja uma estratégia sobreinformativa.

(16) Mais de dois alunos reclamaram de algumas palestras do congresso.

Na sentença (16), em um contexto neutro, em que a pergunta, implícita ou explícita que a introduz seja do tipo “o que aconteceu?", temos a leitura é a de escopo linear, respeitando a sintaxe aberta, em que um grupo de alunos, cuja quantidade é maior que dois, reclamou de um grupo de palestras, cuja quantidade é indefinida. A representação formal para tal leitura está abaixo, em (17):

(17) $\mid\{$ y: y é aluno $\} \cap\{\mathrm{y}: \exists \mathrm{x}: \mathrm{x}$ é palestra $\&[\mathrm{y}$ reclamou de $\mathrm{x}]\} \mid>2$

Paráfrase: O número de alunos que reclamou de um conjunto de palestras é maior que 2.

Esta leitura, de escopo linear apresenta uma estrutura sintática similar às anteriormente apresentadas para leituras de contexto neutro, em que o sintagma na posição de sujeito se mantém em uma posição acima do sintagma na posição de objeto. 


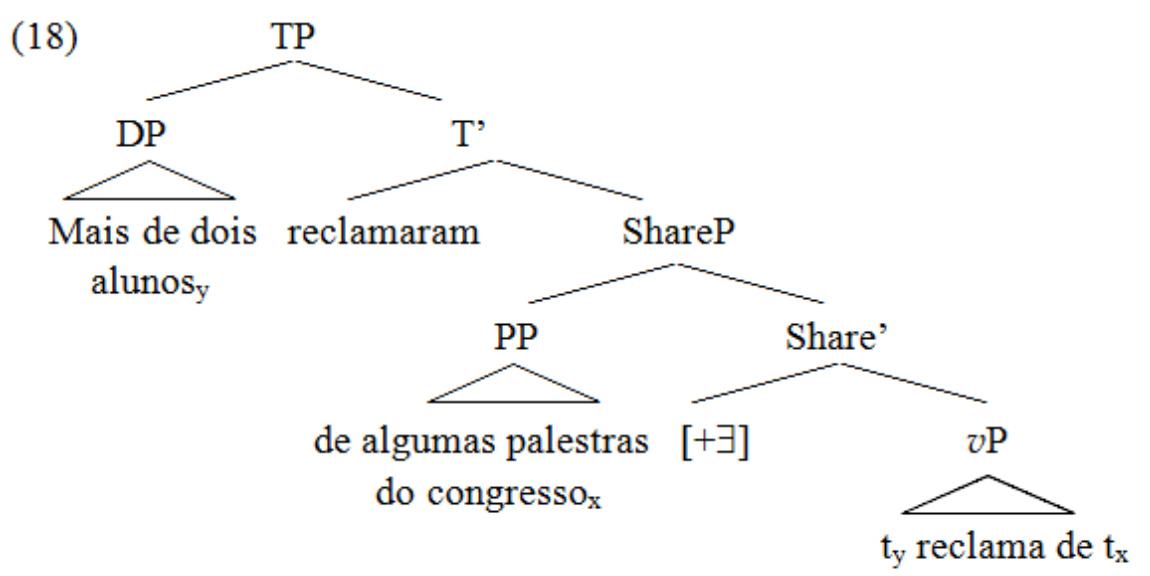

Vejamos, porém, o que ocorre se a sentença em (16) for proferida em um contexto em que o falante faça uso de uma estratégia de resposta sobreinformativa. Imaginemos uma situação em que dois professores estão conversando:

(19) A: Estou chateado porque mais de dois alunos reclamaram da minha palestra, B: Não se preocupe, pois mais de dois alunos reclamaram de $\operatorname{ALGUMAS}_{F S}$ PALESTRAS DO CONGRESSO.

No diálogo acima, o professor B, em uma tentativa de mostrar que "mais de dois alunos reclamarem de palestra" não é uma propriedade exclusiva da palestra do professor A, faz uso da estratégia de resposta sobreinformativa. O falante responde implicitamente a uma questão mais ampla do tipo "Mais de dois alunos reclamaram de quantas palestras?". No entanto, mesmo com o uso desta estratégia que coloca em evidência o conjunto a que a palestra em discussão faz parte, e marca o sintagma quantificado na posição de objeto com foco sobreinformativo, parece que a única leitura possível será a de escopo linear. A estrutura abaixo não parece possível nem mesmo com marcação de FS no sintagma na posição de objeto: 
$(20)$

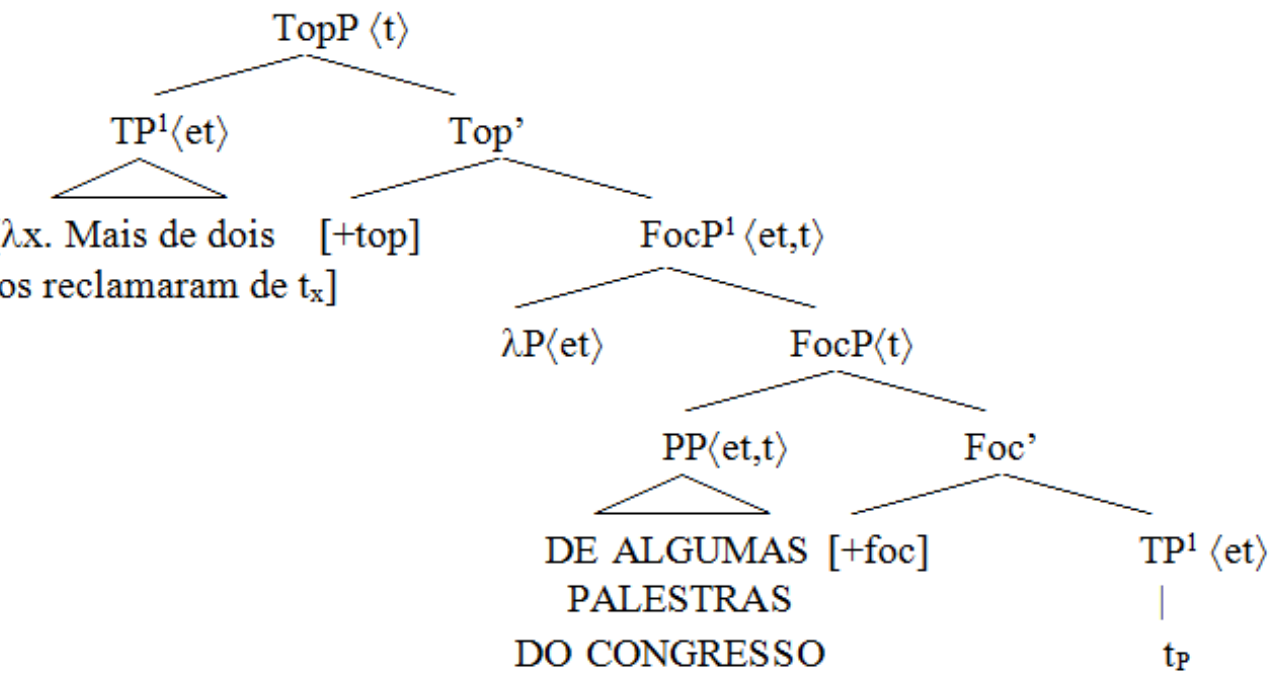

A mesma estrutura que foi utilizada para representar sentenças com o DQP-todo na posição de objeto com traço de foco sobreinformativo (FS) não é adequada para o contexto em (19), em que o sintagma que recebe o traço FS é um GQP “Algumas palestras". Primeiramente, é importante lembrar que nos contextos anteriores, o falante fazia uso ou de um quantificador universal "todo" que realizava um processo de colocar em evidência todo o conjunto, ou um quantificador cardinal como "dez palestras", que também responde completamente a super-questão. O sintagma quantificado "alguns", não pode realizar uma função de evidenciar o conjunto, mas apenas um sub-conjunto deste que, por sua vez, não representa uma quantidade expressiva no contexto. Esta característica semântico-pragmática própria do sintagma quantificado existencial pode estar impossibilitando-o de receber uma marcação de foco sobreinformativo. Vejamos como se daria a $d$-tree para o contexto dado:

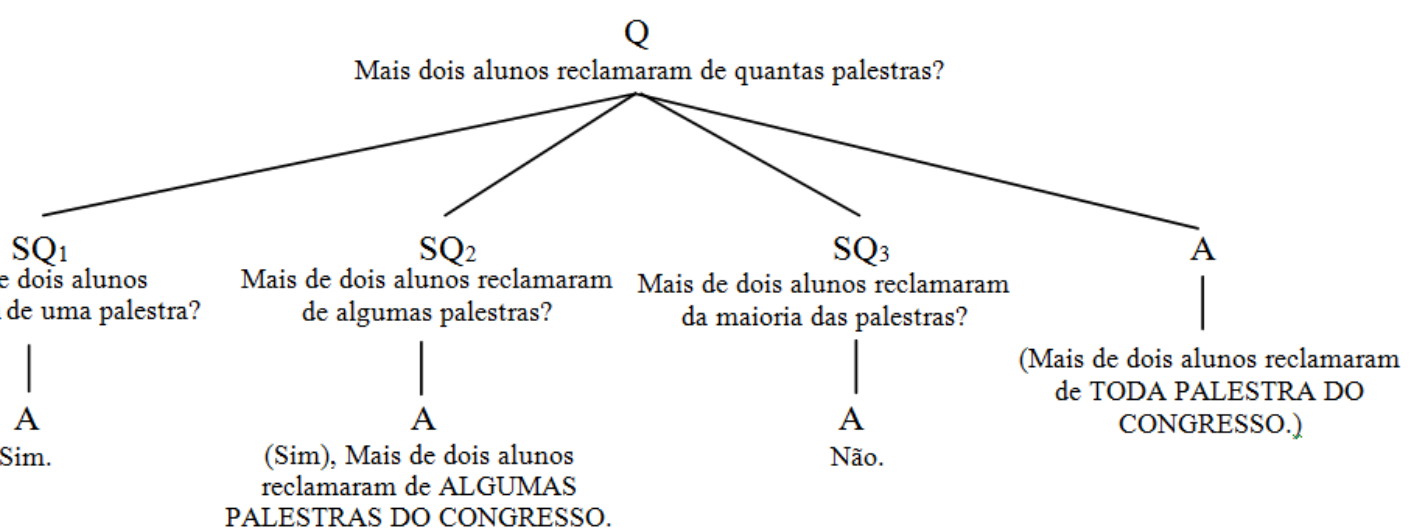

A estrutura em (21) demonstra que a resposta em (19)B não representa uma resposta completa para a super-questão Q. Se considerarmos as sub-questões estão organizadas a partir 
de uma escala de quantidade, em que o QP "toda palestra" representa o ponto mais alto da escala, (19)B, por responder positivamente à $\mathrm{SQ}_{2}$, acarreta apenas $\mathrm{SQ}_{1}$ e não as demais. Quando o falante diz "Mais de dois alunos reclamaram de ALGUMAS PALESTRAS DO CONGRESSO” está respondendo apenas a uma sub-questão implícita e não faz uso de uma estratégia de responder a uma questão maior que acarreta, além da questão sob discussão, a maioria das sub-questões, conforme demonstra a estrutura de d-tree acima.

Diante disso parece que GQP “Algumas palestras do congresso” não é adequado para receber marcação de foco sobreinformativo, visto que esta marcação prosódica é adequada em contextos em o falante se utilize da estratégia de demonstrar que determinada propriedade não é exaustiva em relação ao elemento dado, mas a uma quantidade expressiva de elementos, senão, à totalidade. Sem a marcação de FS, o constituinte não se move em LF para uma posição em FocP na periferia esquerda da sentença. Desta forma, o GQP "algumas palestras do congresso" move-se para uma posição no domínio da periferia esquerda da sentença e se mantém sob o escopo do sintagma quantificado na posição de sujeito, de acordo com a sintaxe aberta. A estrutura sintática para o contexto em (19), então é a mesma anteriormente apresentada para contextos neutros, em (18). ${ }^{42}$

Se em vez de um GQP indefinido ocupar a posição de objeto, um quantificador como "a maioria das", "várias" ou "quase todas", a estratégia de resposta sobreinformativa parece possível. Vejamos os contextos abaixo:

(22) A: Estou chateado porque Mais de dois alunos reclamaram da minha palestra. B: Não é nada pessoal, porque mais de dois alunos reclamaram $\backslash$ DA MAIORIA $F S$ DAS PALESTRAS DO CONGRESSO.

(23) A: Estou chateado porque Mais de dois alunos reclamaram da minha palestra. B: Não é nada pessoal, porque mais de dois alunos reclamaram $\backslash$ DE VÁRIAS VS PALESTRAS DO CONGRESSO.

\footnotetext{
${ }^{42}$ Alguns falantes aceitam uma leitura de escopo inverso mesmo em contexto neutro. Isso porque os dois QPs da sentença (16) admitem leitura cumulativa. Tal leitura pode ser parafraseada por: existe um conjunto de alunos cuja cardinalidade é maior do que dois, esses alunos reclamaram de um conjunto indefinido de palestras. No entanto, em contextos como os discutidos neste trabalho, com respostas sobreinformativas, o sintagma quantificado existencial na posição de objeto parece não ser adequado para receber uma marcação de foco sobreinformativo, o que o habilitaria a se mover para a posição de Spec de FocP. Por isso, descartaremos aqui a leitura cumulativa que a sentença (16) possa apresentar.
} 
(24) A: Estou chateado porque Mais de dois alunos reclamaram da minha palestra.

B: Não é nada pessoal, porque mais de dois alunos reclamaram $\backslash$ DE QUASE TODAS $_{F S}$ AS PALESTRAS DO CONGRESSO.

O uso da estratégia sobreinformativa nos contextos acima é apropriado. Esta possibilidade se dá pela força pragmática dos sintagmas quantificados "quase todos", "a maioria de" e "vários", que acarretam sintagmas quantificados como "alguns", "pelo menos um" e "um". Vejamos como é representada a $d$-tree do contexto dado em (22), por exemplo:

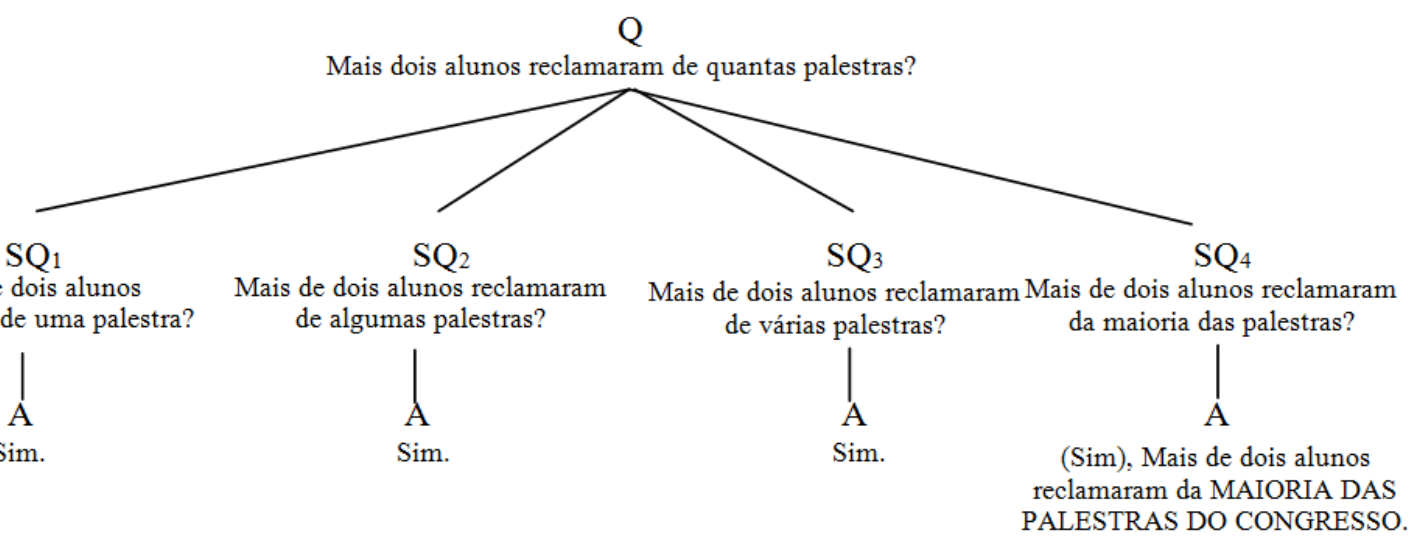

É importante ressaltar que neste caso, a resposta não é uma resposta completa a super-questão e sim uma resposta à sub-questão $\left(\mathrm{SQ}_{4}\right)$. Como as sub-questões estão organizadas a partir de uma escala de quantidade, $\mathrm{SQ}_{4}$ acarreta as demais sub-questões, pois representa um ponto da escala relativamente alto. Então, tal resposta parece ser uma boa estratégia sobreinformativa para o contexto dado. Com o uso de tal estratégia, indicada pela marcação de foco sobreinformativo no sintagma quantificado na posição de sujeito, o falante pretende amenizar a propriedade negativa de "mais de dois alunos reclamar" que recai sobre a palestra do professor A, demonstrando que tal propriedade não é exclusiva de sua palestra, e sim de uma grande quantidade de palestras. Lembremos que, como mencionado anteriormente, a palestra do professor A não é acarretada logicamente pela resposta dada pelo professor B, mas aceita pelos participantes e acomodada no common ground. A marcação de foco sobreinformativo no determinante que passou por um processo de focalização complexo, de alargamento de domínio, mostra que este assume uma posição que c-comanda o sintagma quantificado na posição de sujeito, como mostra a árvore sintática abaixo. 
(26)

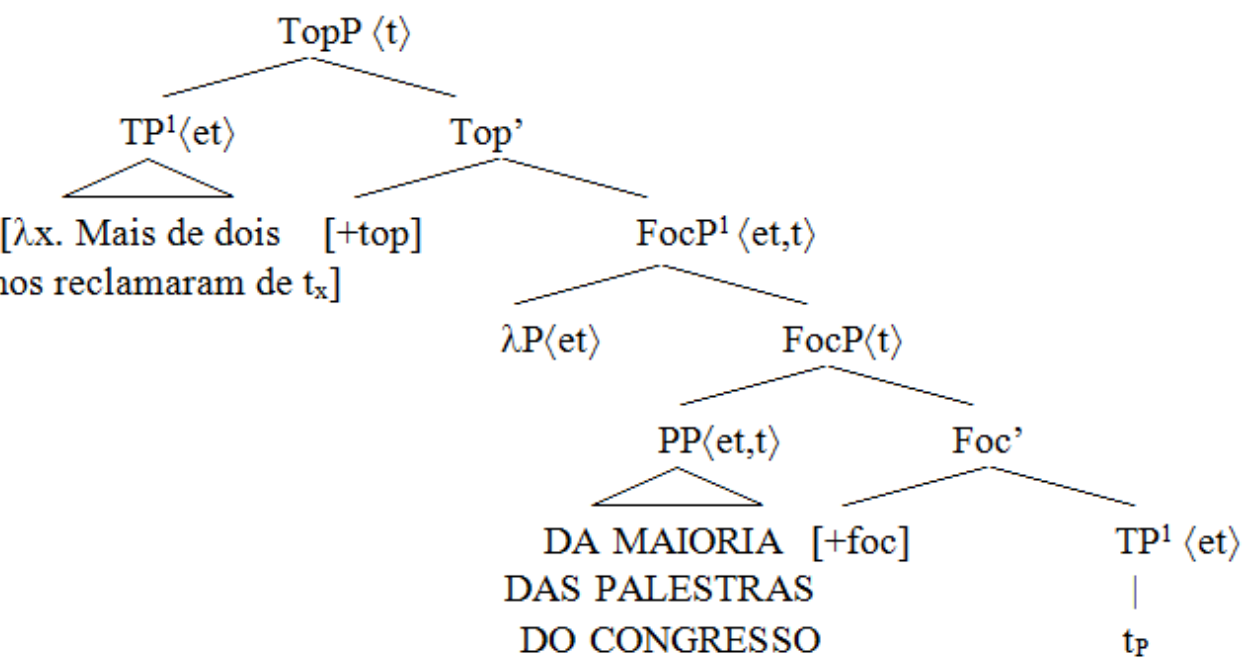

Assim como os demais exemplos, calculando passo a passo a composição semântica desta estrutura, chegaremos à seguinte formulação lógica, que representa a leitura de escopo invertido.

(27) $\mid\{x: x$ é palestra $\} \cap \mid\{$ y: y é aluno $\} \cap\{$ y: [y reclamou de $\mathrm{x}]\} \mid>2\}|>|\{x: \mathrm{x}$ é palestra $\} \cap \mid\{$ y: y é aluno $\} \cap\{\mathrm{y}:[$ y não reclamou de $\mathrm{x}]\} \mid>2\} \mid$

Paráfrase: $O$ número de palestras que foi alvo da reclamação de mais de dois alunos maior do que o número de palestras que não foi alvo da reclamação de mais de dois alunos.

Dado o exemplo acima com o sintagma quantificado "a maioria de", podemos concluir que a estratégia discursiva de resposta sobreinformativa será válida somente com o uso de um quantificador que tenha força pragmática no contexto e que acarrete uma quantidade relevante de outros quantificadores. Somente assim, o argumento terá força suficiente para ser usado como uma resposta que amenize ou enfatize a propriedade dada ao elemento em questão. Somente o uso dos sintagmas quantificados "todo", "a maioria de", "quase todos", "vários" e um cardinal como "dez palestras" será capaz de produzir a implicatura de que o falante, ao demonstrar que a propriedade negativa de "mais de dois alunos reclamar" não é exclusiva das palestras em discussão, mas de um número significativo de palestras, quer amenizar a situação posta. Vale ressaltar que o sintagma cardinal só será adequado para a estratégia se for um numeral expressivo para o contexto. No caso dos exemplos anteriores com o sintagma "dez palestras", a marcação de foco sobreinformativo só é possível em contextos em que a quantidade "dez" seja relevante e capaz de justificar o uso 
de tal resposta para amenizar a carga negativa da propriedade recaída sobre a palestra em questão. Do contrário, não receberá marcação de FS, e consequentemente, não poderá assumir uma posição que gere a leitura de escopo invertido. Compare com o contexto abaixo:

(28) A: Estou chateado porque mais de dois alunos reclamaram da minha palestra.

B: \#Não fique chateado! Não é nada pessoal, mais de dois alunos reclamaram de $\backslash_{\text {DUAS }}^{F S}$ PALESTRAS.

A estratégia aqui, assim como com o GQP "Alguns", parece não funcionar, pois o argumento "duas palestras" não tem uma representação forte suficiente no contexto para que a resposta sobreinformativa produza a implicatura desejada, na qual o falante B deseja amenizar a situação do falante A. Vejamos, na próxima seção, se na posição de sujeito o sintagma quantificado indefinido permite leitura de escopo inverso ou a sentença permanece imune à marcação de foco sobreinformativo.

\subsubsection{Sintagmas quantificados existenciais}

Já vimos que um GQP indefinido “alguns" na posição de objeto não é pragmaticamente adequado para receber marcação de foco sobreinformativo, e consequentemente, não pode se mover para uma posição de c-comande o QP na posição de sujeito. Vejamos agora se uma sentença com esse GQP indefinido na posição de sujeito pode apresentar leitura de escopo invertido. Considere, por exemplo, a sentença abaixo:

(29) Alguns alunos reclamaram de toda palestra do congresso.

Novamente, em um contexto dito neutro, a única interpretação possível é a de escopo linear. O quantificador existencial correspondente ao sintagma indefinido (GQP) na posição de sujeito tem escopo sobre o quantificador universal (DQP) que ocupa a posição de objeto. Em termos formais, apresentamos a interpretação lógica da sentença acima em (30) e estrutura sintática em (31):

(30) $\exists \mathrm{Y}$ : Y são alunos \& [ $\forall \mathrm{x}: \mathrm{x}$ é palestra do congresso $\rightarrow[\mathrm{Y}$ reclamou de $\mathrm{x}]]$ Paráfrase: existe um grupo de alunos, sendo que estes reclamaram de todas as palestras do congresso. 
(31)

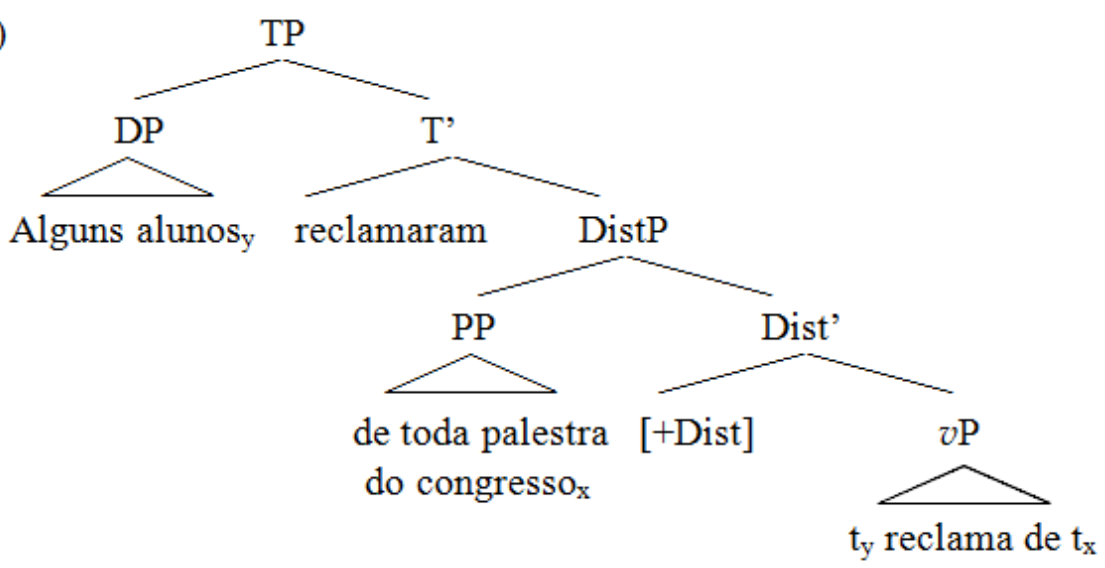

De acordo com (30), para que (29) seja verdadeira é preciso que haja um grupo de alunos tal que cada um deles tenha reclamado de todas as palestras do congresso. A representação sintática em LF apresenta a mesma hierarquia que a estrutura da sintaxe aberta, como nos exemplos anteriores.

Tentemos agora criar um contexto que facilitaria a leitura de escopo invertido de acordo com a qual todas as palestras do congresso foram alvo de reclamação de alguns alunos, sem que tenha havido necessariamente alunos que reclamaram de todas as palestras. Essa leitura potencial está representada em (32):

(32) $[\forall \mathrm{x}: \mathrm{x}$ é palestra do congresso $\rightarrow[\exists \mathrm{Y}: \mathrm{Y}$ são alunos \& Y reclamou de $\mathrm{x}]]$ Paráfrase: Para cada palestra $x$, existe um grupo de alunos que reclamou de $x$.

Imagine que um professor se queixe com um colega de que alguns alunos reclamaram da palestra dele, como no diálogo a seguir:

(33) A: Estou chateado: Alguns alunos reclamaram da minha palestra.

B: Não pense que seja pessoal, porque alguns alunos reclamaram de $\backslash \mathrm{TODA}_{F S}$ PALESTRA DO CONGRESSO.

Nesse caso, mesmo diante de um contexto que, como vimos mais acima, favorece a inversão de escopo, a leitura em (32), de escopo inverso não parece possível. O problema desta vez não parece ser o uso da estratégia de resposta sobreinformativa, visto que o sintagma quantificado que recebe a marcação de foco sobreinformativo (FS) é o quantificador universal "todo". Como vimos anteriormente, tal quantificador é adequado para o uso desta 
estratégia. O bloqueio da inversão de escopo, assim como a proposta dada para sintagmas cardinais interpretados como GQPs, está na estrutura sintática. Segundo Beghelli e Stowell (1997), um GQP pode ocupar duas posições distintas na árvore. Se o GQP tem apenas um traço existencial [+existencial], este vai se mover para a posição de Spec de ShareP, que se localiza dentro da categoria CP. No entanto, se além do traço [+existencial], o GQP tiver um traço [+referência de grupo], ou seja, tal sintagma quantificado seja identifique um grupo específico de elementos, este se move para a Spec RefP, uma posição fora do domínio de CP. Tal posição também pode ser considerada posição de tópico. Segundo Negrão (1999), essa posição que em PB é ocupada pelo sujeito da predicação na sintaxe aberta, é preenchida pelo GQP indefinido "Alguns" quando este está na posição de sujeito. Neste caso, se o GQP vai pra uma posição fora do $\mathrm{CP}$, consequentemente, está fora do domínio de FocP, portanto, a leitura de escopo invertido torna-se impossível, mesmo em contextos de foco sobreinformativo. A estrutura sintática para o contexto (33), então é a mesma dada na seção anterior para do QP "dois alunos" interpretado como GQP. ${ }^{43}$

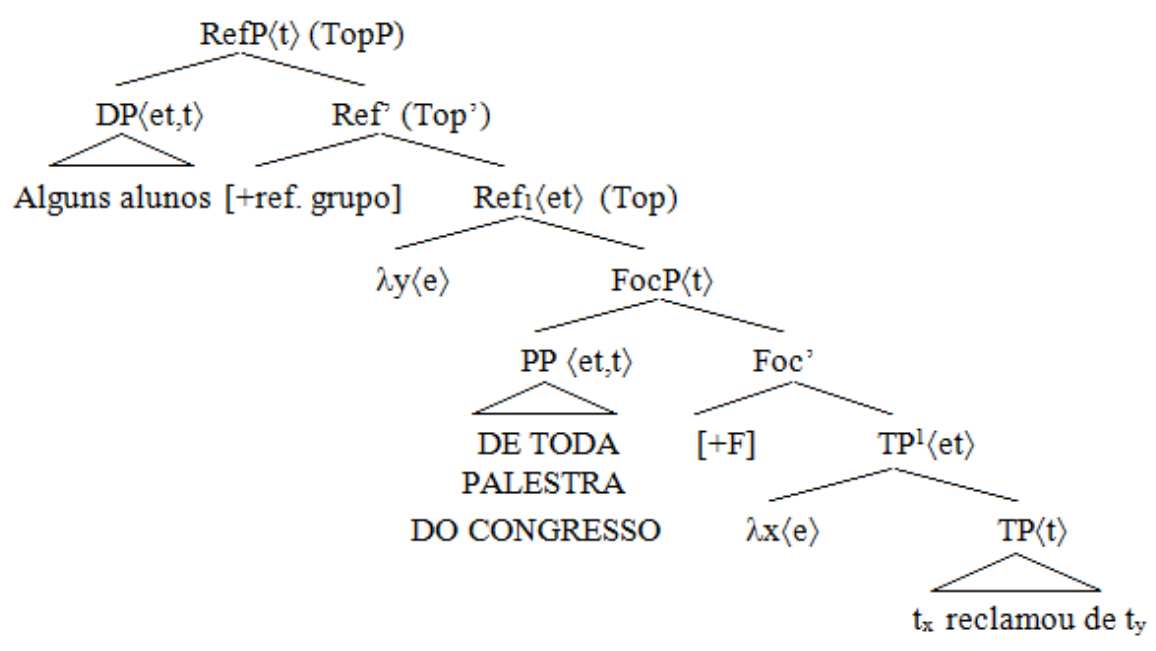

$\mathrm{Na}$ estrutura apresentada acima, o quantificador na posição de objeto entra na derivação com um traço de foco e se move para a posição de Spec de FocP, a fim de checar este traço. Ainda, o sintagma na posição de sujeito, "alguns alunos" entra na derivação com um traço não valorado de [+ referência de grupo]. Tal traço indica que o QP tem a função lógica de sujeito da predicação e denota um grupo determinado de entidades ou indivíduos. Para checar seu traço, o GQP na posição de sujeito se move para a posição de Spec de RefP e

\footnotetext{
${ }^{43}$ Não é claro que indefinidos como "alguns alunos" possam assumir posição de tópico. Não há consenso na literatura em relação a isso. Também não é óbvio que a categoria RefP esteja na mesma posição sintática que a categoria TopP. Tais questões são bastante pertinentes e devem ser mais bem aprofundadas em trabalhos futuros.
} 
deixa um vestígio em TP. Se fizermos a derivação semântica passo a passo, veremos que o sintagma GQP na posição de sujeito mantém seu domínio sobre o QP na posição de objeto. O que impede de gerar uma leitura de escopo inverso. Desta maneira, o sintagma quantificado com traço de foco sobreinformativo não pode exercer domínio sobre o GQP na posição de sujeito e por este motivo não podemos ter leitura de escopo invertido em sentenças com GQP indefinido na posição de sujeito nem mesmo em contextos de não-exaustividade, que como vimos nos exemplos anteriores, facilitam a inversão de escopo.

Ainda com relação ao contexto (33), alguns falantes do PB aceitam uma leitura de escopo invertido para a sentença (33)B. Uma possível explicação seria que estes falantes estão interpretando o QP "alguns alunos" como um sintagma de contagem como "mais de um aluno". A leitura, então, seria que para cada palestra do congresso x, uma quantidade de alunos maior do que um reclamou de x. Em termos formais:

(35) $\forall \mathrm{x}$ : $\mathrm{x}$ é palestra do congresso $\rightarrow \mid\{\mathrm{y}: \mathrm{y}$ é aluno $\} \cap\{\mathrm{y}:[\mathrm{y}$ reclamou de $\mathrm{x}]\} \mid>1$

Paráfrase: para cada palestra do congresso $x$, a quantidade de alunos que reclamou x é maior do que um.

Desta forma, seria possível, então a inversão de escopo, já que "alguns" está sendo interpretado como um CQP, que permite inversão de escopo, e não como um GQP com traço [+ referência de grupo], que necessariamente move-se para a posição de Spec de TopP, posição que c-comanda FocP e não permite inversão nem mesmo em contexto de respostas sobreinformativas.

Nesta seção pudemos observar que há uma restrição sintática para GQPs indefinidos "alguns" ou cardinais interpretados como denotadores de grupo na posição de sujeito. Pudemos perceber que tais GQPs não vão permitir leitura de escopo invertido nem mesmo em contextos de marcação de foco. Isto porque GQPs nesta posição em PB assumem a posição de sujeito da predicação e necessariamente são dotados de um traço [+ ref. de grupo] que indica que se referem a um grupo específico no contexto. Nestes casos, mesmo em um contexto com estratégia de resposta sobreinformativa, que facilita a inversão de escopo, tal leitura não é possível. Isto porque o GQP, para checar seu traço [+ referência de grupo], move-se para Spec de RefP ou TopP, onde o sintagma com traço de foco não pode exercer domínio sobre ele. Porém se o falante atribuir ao QP "alguns" uma interpretação de sintagma de contagem (CQP), a leitura de escopo inverso, assim como com os demais CQPs.

Vejamos nas seções seguintes se outros tipos de sintagmas quantificados na posição 
de sujeito apresentam algum tipo de restrição para a leitura de escopo invertido.

\subsubsection{Sintagmas quantificados distributivos}

Até agora vimos que sentenças com CQPs na posição de sujeito interagindo com quantificadores como "todo", “a maioria de", "vários", "quase todos”, cardinais como "dez" podem apresentar leitura de escopo invertido em um contexto em que o falante deseje mostrar que determinada propriedade não é exaustiva em relação ao elemento em discussão. O GQP indefinido "alguns" na posição de objeto, no entanto, não é capaz de tomar escopo amplo sobre o sintagma quantificado na posição de sujeito. Tal impossibilidade é de natureza semântico-pragmática, pois se dá pelo motivo de "alguns" não ser adequado contextualmente para ser aplicado em uma estratégia de respostas sobreinformativas. Este mesmo sintagma quantificado na posição de sujeito, se interpretado como um sintagma denotador de grupo não permite inversão de escopo mesmo em contextos marcados por foco sobreinformativo. Neste caso, a restrição é sintática, pois o GQP "alguns" na posição de sujeito se move para a posição de Spec de RefP, fora do domínio da categoria funcional FocP, a fim de checar seu traço [+ referência de grupo]. Isto também ocorre com sintagmas quantificados numerais que são interpretados como denotadores de grupo (GQPs). Vejamos agora o que ocorre com sentenças que apresentam o DQP-todo na posição de sujeito.

(36) Todo aluno de lingüística reclamou de mais de dez palestras do congresso.

Em um contexto neutro, em que a questão sob discussão seja do tipo "O que aconteceu?", a leitura mais saliente para a sentença acima é de que cada um dos alunos reclamou de mais de cinco palestras. Estas podem ser distintas para cada um dos alunos ou coincidirem de serem as mesmas. A leitura de escopo linear pode ser representada como segue.

(37) $\forall$ y: y é aluno $\rightarrow \mid\{x: x$ é palestra $\} \cap\{x:[y$ reclamou de $\mathrm{x}]\} \mid>10$

Paráfrase: Para cada aluno $x$, o número de palestras que $x$ reclamou é maior do que dez.

No entanto, podemos imaginar um contexto em que um professor ao comentar que "Todo aluno de linguística reclamou de sua palestra", é consolado pelo colega quando este diz: 
(38) Não fica chateado porque todo aluno de linguística reclamou de $\backslash$ MAIS DE DEZ $F S$ PALESTRAS DO CONGRESSO.

Neste contexto, o professor faz uso de uma estratégia discursiva de resposta sobreinformativa. Na tentativa de mostrar que a propriedade de todo aluno reclamar não é exclusiva do colega, mas sim de um conjunto de palestras, cuja quantidade é maior do que dez, o falante responde a uma pergunta implícita mais ampla do tipo "Quantas palestras x são tais, tal que todo aluno reclamou de $x$ ?”. Tal leitura tem sua representação formal apresentada em (39):

(39) $\mid\{x: x$ é palestra $\} \cap\{x: \forall y:$ y é aluno $\rightarrow[$ y reclamou de $\mathrm{x}]\} \mid>10$

Paráfrase: o número de palestras que todos os alunos reclamaram é maior do que dez.

$\mathrm{Na}$ estrutura sintática para a leitura de escopo invertido relativa ao contexto (38), como nas demais, aqui vistas, o sintagma quantificado com acento de foco sobreinformativo se move para uma posição que tenha domínio sobre o sintagma quantificado na posição de sujeito, a fim de checar seu traço de foco. Teremos então a seguinte estrutura:

(40)

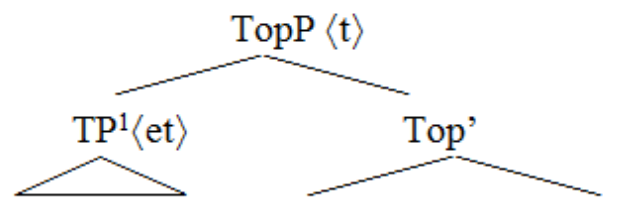

$[\lambda x$. Todo aluno de $[+$ top $]$ linguística reclamou de $t_{\mathrm{x}}$ ]

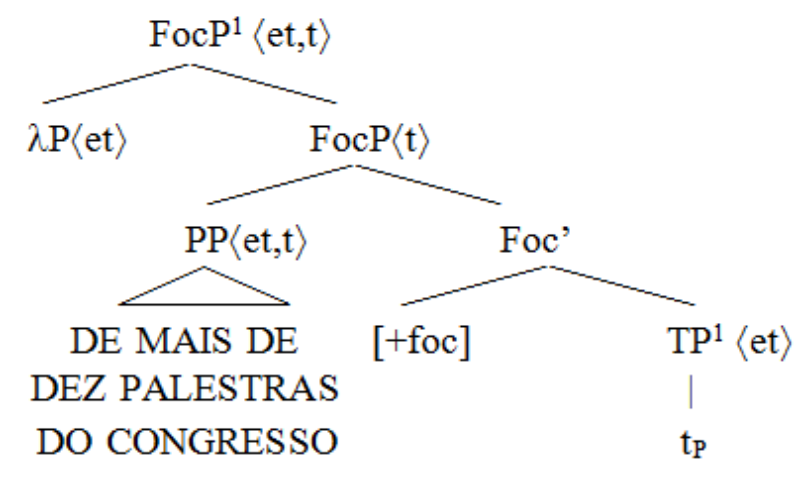

O mesmo ocorre se tivermos um CQP cardinal como "dez palestras" na posição de objeto, como exemplo abaixo. Em contexto neutro, a leitura de escopo linear prevalece. 
Porém, em um contexto em que o falante faça uso da estratégia de resposta sobreinformativa, deixando claro que a propriedade em discussão não é exclusiva do elemento dado, a interpretação de que existem dez palestras que foram alvo da reclamação de todos os alunos pode ocorrer.

(41) A: Todo aluno de linguística reclamou da minha palestra.

B: Não é nada pessoal, pois todo aluno reclamou de $\backslash D_{E Z}$ PALESTRAS DO CONGRESSO.

No contexto dado acima, o falante $\mathrm{B}$, ao utilizar a estratégia de resposta sobreinformativa, quer enfatizar que a propriedade negativa de "todo aluno reclamar" não é específica da palestra do falante B, mas de "dez palestras do congresso". Lembremos que tal estratégia será adequada somente se a quantidade de dez palestras for um número expressivo no contexto. A representação formal da interpretação de escopo invertido é apresentada abaixo, bem como sua $d$-tree.

(42) $\mid\{\mathrm{x}: \mathrm{x}$ é palestra $\} \cap\{\mathrm{x}: \forall \mathrm{y}: \mathrm{y}$ é aluno $\rightarrow[\mathrm{y}$ reclamou de $\mathrm{x}]\} \mid=10$

O número de palestras que todos os alunos reclamaram é igual a dez.

(43)

Q Todo aluno de linguística reclamou de quantas palestras?

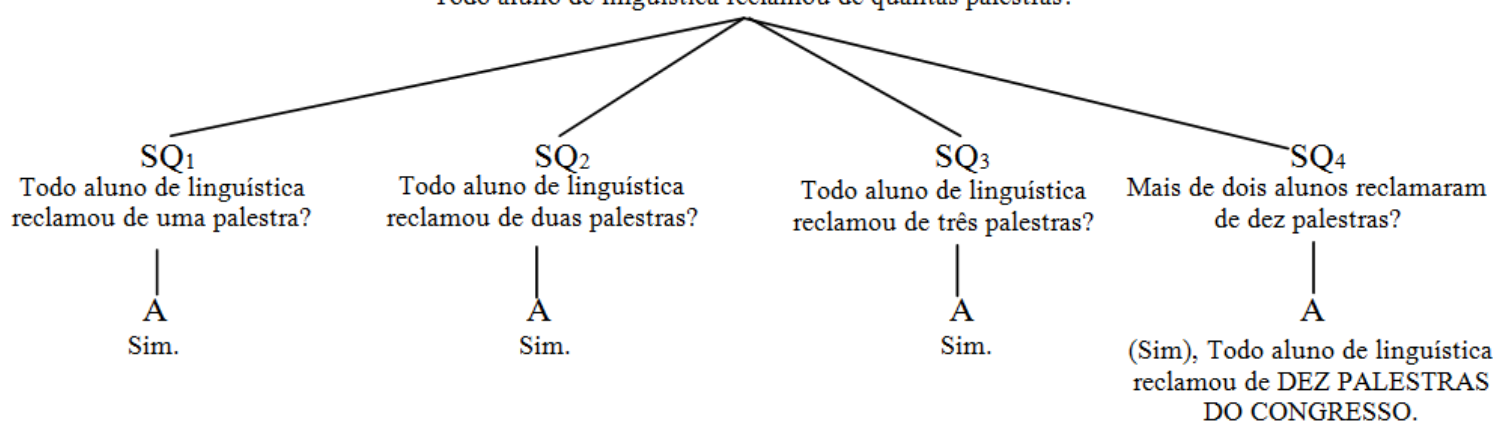

$\mathrm{Na}$ árvore do discurso acima, podemos perceber que a resposta dada pelo falante em (41) representa uma resposta completa para a super-questão Q. Tal resposta é adequada para o uso da estratégia de resposta sobreinformativa. No contexto dado, como já discutimos anteriormente, a resposta do professor B não acarreta logicamente a asserção de A, mas é aceita pelos falantes e acomodada no common ground.

Continuando com testes com DQP-todo na posição de sujeito, se o sintagma 
quantificado na posição de objeto for um GQP existencial como na sentença abaixo, pelo mesmo motivo visto anteriormente, tal sintagma não tem força semântico-pragmática para tomar escopo sobre o sintagma quantificado na posição de sujeito.

(44) A: Todo aluno de linguística reclamou da minha palestra.

B: Todo aluno de linguística reclamou de $\backslash$ ALGUMAS ${ }_{F S}$ PALESTRAS DO CONGRESSO.

Se pensarmos em uma situação como as anteriores de que há dois professores conversando sobre o congresso que participaram e um deles comenta que todo aluno de linguística reclamou de sua palestra. $\mathrm{O}$ outro para tentar amenizar a situação diz: Não fica chateado porque todo aluno de linguística reclamou de ALGUMAS PALESTRAS DO CONGRESSO. Neste contexto, parece não ser adequado o uso da marcação de foco sobreinformativo no GQP indefinido na posição de objeto. No contexto dado, não podemos obter a leitura de escopo invertido porque o GQP indefinido, como já vimos nas seções anteriores, não é um quantificador pragmaticamente adequado para o uso da estratégia de resposta sobreinformativa, pois não representa um ponto alto da escala que acarrete uma quantidade expressiva de elementos. A leitura que prevalece, então, é a de escopo linear, representada formalmente em (45), em que o DQP universal permanece em uma posição mais alta que o GQP existencial.

(45) $\forall$ y: y é aluno $\rightarrow \exists x$ : x é palestra \& [y reclamou de $\mathrm{x}]$

Paráfrase: Para cada aluno $x$, existe um conjunto de palestras que $x$ reclamou.

É importante salientar que a sentença "Todo aluno de linguística reclamou de algumas palestras", em um contexto neutro, pode apresentar uma leitura compatível com a situação em que o mesmo conjunto de palestras foi alvo da reclamação de todos os alunos de linguística. No entanto, nossa proposta é que em contextos de resposta sobreinformativa, como o dado acima, em (44), a leitura de escopo inverso não é possível porque GQPs indefinidos não são adequados pragmaticamente para receber marcação de foco sobreinformativo. ${ }^{44}$

\footnotetext{
${ }^{44}$ Além do DQP “todo", temos em PB o DQP “cada”, que segundo Negrão (1999) é um quantificador distributivo forte no português brasileiro. Tal quantificador, entretanto, parece não ser adequado em respostas sobreinformativas. Observe o contexto abaixo:
} 


\subsection{RESUMO DO CAPÍTULO}

Neste capítulo pudemos observar ao menos uma possibilidade de inversão de escopo no português brasileiro: em contextos de estratégias discursivas de respostas sobreinformativas, em que o falante deixa claro que a propriedade em discussão não é exaustiva em relação ao elemento dado. Nestes contextos, o sintagma quantificado recebe uma marcação prosódica de foco sobreinformativo (FS) e tal marcação indica que este constituinte ocupa a posição de especificador de FocP, na periferia esquerda da sentença. Tal posição c-comanda a posição para qual o sintagma quantificado sujeito se move e gera uma leitura de escopo inverso. No entanto, pudemos observar que há sintagmas que são imunes à inversão de escopo, mesmo em contextos em que o falante faz uso de respostas sobreinformativas, o que facilitaria tal inversão.

Um exemplo de sintagma quantificado que é resistente à marcação de foco sobreinformativo e não permite a inversão de escopo são os GQPs indefinidos como "alguns". Sentenças com esse tipo de sintagma, estando na posição de sujeito ou de objeto e interagindo com qualquer tipo de sintagma quantificado, apresentam tanto em contextos neutros como em marcados por foco sobreinformativo uma leitura de escopo linear. Tal restrição se dá por dois motivos. Em posição de objeto, a restrição se dá no nível semântico-pragmático. Sentenças com o GQP “alguns” na posição de objeto não possuem leitura de escopo invertido porque este tipo de sintagma quantificado não representa um argumento forte no contexto para ser utilizado em uma estratégia de resposta sobreinformativa. Na posição de sujeito, "alguns" é imune à inversão de escopo por apresentar um traço [+referência de grupo]. Este traço o fará mover para a posição de Spec de TopP (ou RefP). Segundo a hierarquia proposta por Beghelli \& Stowell (1997), esta categoria localiza-se acima de CP, ou seja, fora do domínio de FocP, categoria que abriga sintagmas com marcação de foco. Desta maneira, mesmo em um contexto em que o constituinte na posição de objeto receba marcação de FocP, o GQP

(i)A: Estou chateado: mais de dois alunos reclamaram da minha palestra.

B: Não se preocupe, não é nada pessoal, pois mais de dois alunos reclamaram de $\backslash$ CADA ${ }_{F S}$ PALESTRA DO CONGRESSO.

A sequência acima, diferentemente do contexto com o QP "todo" parece não soar naturalmente. A resposta mais natural seria algo do tipo: "Mais de dois alunos reclamaram de TODA PALESTRA DO CONGRESSO". Essa estranheza pode ser explicada pelo motivo de que o quantificador "cada" não faz parte de uma escala de quantidade como "todo", que representa o ponto mais alto da escala. Partindo do pressuposto que contextos de respostas sobreinformativas com o DQP cada não são naturais, não apresentaremos análise com este tipo de quantificador. 
"alguns" vai se mover para uma posição mais alta na estrutura, que c-comanda o constituinte com marcação de foco.

CQPs cardinais (dez) e CQPs cardinais modificados (mais de cinco) são sensíveis à marcação de foco e, em posição de sujeito permitem leitura de escopo invertido nos casos em que interage com DQPs ou outro CQP. Com GQPs indefinidos, a leitura de escopo invertido não é possível, pelos motivos que já apresentamos acima. Na posição de objeto, sintagmas cardinais, se recebem marcação de foco sobreinformativo, podem apresentar leitura de escopo invertido. No entanto é importante salientar que tais sintagmas só receberão marca de foco sobreinformativo em contextos em que sejam representativos, a ponto de poderem ser usados em estratégias de resposta sobreinformativa. Do contrário, assim como GQPs indefinidos, não serão pragmaticamente fortes suficientes para receber marcação de foco sobreinformativo. Ainda, se o sintagma numeral cardinal na posição de sujeito ser interpretado como denotador de grupo, um GQP, este, assim como o GQP indefinido não permitirá leitura de escopo inverso pelo mesmo motivo que "alguns".

DQPs todo na posição de sujeito permitem inversão de escopo com CQPs, mas não com GQPs, como com os demais sintagmas quantificados, o que indica certa regularidade no comportamento de sintagmas quantificados em contextos marcados por foco sobreinformativo. 
A partir desta análise preliminar, podemos observar que é possível haver inversão de escopo em sentenças quantificadas do português brasileiro. No entanto tal inversão não ocorre em contextos neutros, como já havia afirmado Negrão (1999), pois nossa língua privilegia marcar na sintaxe aberta as relações que em outras línguas ocorrem em forma lógica. A inversão de escopo pode ocorrer em contextos em que elementos discursivos como tópico e foco são marcados.

Nestes dados, pudemos observar pelo menos uma possibilidade de contexto em que pode haver inversão de escopo em PB. Em contextos nos quais o falante faz uso de uma estratégia discursiva, a que chamamos de resposta sobreinformativa, vimos que é possível ter uma leitura de inversão em que o sintagma quantificado na posição de objeto c-comanda o sintagma quantificado na posição de sujeito. Tal estratégia ocorre quando o participante da conversa deseja deixar claro que a propriedade em discussão não é exaustiva em relação ao elemento dado no contexto. Com isso, o participante quer exaltar tal propriedade, se esta tem carga positiva, ou amenizar, se a propriedade possui carga negativa.

Com o uso desta estratégia, o sintagma na posição de objeto recebe uma marcação prosódica peculiar, de foco sobreinformativo. Foco sobreinformativo neste estudo possui um conceito diferente dos apresentados por outros autores como Zubizarreta (1998), ErteschikShir (1998); (2007), Mioto (2003). O conceito proposto não se refere a um contexto em que o elemento focalizado nega o elemento dado, mas a contextos de respostas sobreinformativas, em que o elemento dado é incluído no elemento ou conjunto de elementos focalizado. Nestes contextos, a contrastividade se dá pela não exaustividade da propriedade em discussão.

Mais especificamente, a marcação de foco sobreinformativo recai sobre o determinante quantificado, que representa a informação nova no discurso, já que o NP, a propriedade em questão, já foi dada. Esta marcação no determinante realiza uma operação complexa de focalização em que, a partir do elemento de tópico ocorre um alargamento de domínio em que todo conjunto ou parte do conjunto a que este elemento faz parte, é evidenciado e passa a ser focalizado no contexto.

Com a marcação de foco sobreinformativo, o sintagma quantificado objeto, que se encontra em sua posição de caso, inferior ao QP sujeito, passa a assumir uma posição em LF 
que c-comanda o último, a posição de Spec de FocP na periferia esquerda da sentença (cf. Rizzi (1997), Belletti(2001), Mioto (2003)).

Entretanto, não é em todos os casos nem com todos os tipos de QPs que ocorre inversão de escopo. Há sintagmas quantificados que não apresentam leitura de inversão mesmo em contextos em que este sintagma é evidenciado a partir de uma marcação prosódica de foco sobreinformativo. É o caso do GQP existencial "alguns" que tanto na posição de sujeito quanto na posição de objeto permanece imune à inversão de escopo. Na posição de objeto, a impossibilidade se dá por restrições semântico-pragmáticas. O GQP "alguns" não pode receber marcação de foco sobreinformativo por não representar, pragmaticamente, força e expressividade para ser usado como estratégia de resposta sobreinformativa. Isto porque tal QP não se localiza em um ponto relativamente alto da escala e, portanto não acarreta outros QPs. O mesmo ocorre com sintagmas quantificados cardinais como "dois alunos" se estes não forem representativos suficientes para serem usados na estratégia de resposta sobreinformativa. Se o GQP “alguns” estiver na posição de sujeito, a impossibilidade de inversão se dá por restrições sintático-semânticas. Nesta posição, tal GQP possui um traço semântico [+referência de grupo] que deve ser checado. Para checá-lo o QP se move para a posição de Spec de RefP, que segundo a hierarquia proposta por Beghelli \& Stowell (1997), se localiza em uma posição acima de CP. Nesta posição, o QP que está em Spec de FocP não pode exercer domínio sobre o GQP existencial. Desta maneira, a leitura de inversão de escopo torna-se impossível. Sintagmas quantificados cardinais na posição de sujeito que são interpretados como denotadores de grupo também não permitem inversão pela mesma restrição ocorrida com o GQP existencial.

Outros QPs como DQPs (todo), CQPs cardinais modificados (mais de dois), CQPs cardinais (dez) são mais sensíveis à marcação de foco sobreinformativo, e aceitam tal marcação prosódica quando na posição de objeto. Na posição de sujeito, movem-se para uma posição abaixo da categoria funcional FocP, em que são c-comandados pelo QP que tenha tal traço. Desta maneira, permitem inversão de escopo em quaisquer das duas posições sintáticas, desde que não interajam com GQPs existenciais ou cardinais na posição de objeto que não possam receber marcação de foco sobreinformativo, como vimos acima.

O QP indefinido "alguns", se for interpretado como um sintagma de contagem, em que lhe é atribuída uma leitura cardinal como "mais de um", pode permitir inversão de escopo, isso porque ele será neste contexto um CQP.

Diante destas constatações, podemos afirmar que o Português Brasileiro permite inversão de escopo em sentenças que apresentem interação de sintagmas quantificados quando 
estas são inseridas em contextos marcados por elementos discursivos como tópico e foco. Nesta pesquisa, pudemos observar pelo menos um contexto possível, em que o falante faz uso de uma estratégia discursiva de resposta sobreinformativa e marca prosodicamente o sintagma na posição de objeto a fim de evidenciá-lo no contexto. Isto mostra que em contextos marcados, nossa língua pode apresentar leituras de inversão de escopo, que não correspondem à ordem linear da sentença. 


\section{TIPOS DE FOCO}

\section{- Foco informacional, de Zubizarreta (1998)}

Tem a função de identificar a informação nova, requerida pelo contexto.

Exemplo:

A: Quem foi pra festa?

B: O JOÃO $F$ foi (pra festa).

\section{- Foco contrastivo, de Zubizarreta (1998)}

Tem a função de negar a informação sobre um elemento dado pelo contexto e trazer informação sobre um novo elemento.

Exemplo:

A: Quem foi pra festa?

B: O JOÃO ${ }_{F}$ foi (pra festa).

\section{- Foco identificacional, de Kiss (1998)}

Tem um traço de exaustividade. Elementos marcados por este tipo indicam que são os únicos que possuem a propriedade em discussão.

Exemplo:

A: Quem comprou esse livro?

$\mathrm{B}$ : Foi O JOÃO ${ }_{F}$ que comprou. (e ninguém mais)

\section{- Foco contrastivo, de Erteschik-Shir (2007)}

Realiza uma operação complexa de focalização, em que dentro de um conjunto determinado pelo contexto, focaliza um elemento e descarta os demais. 
Exemplo:

A: Quem foi pra festa, o João ou o Pedro?

B: O JOÃO $F$ foi (e não o Pedro).

\section{- Foco restritivo, de Erteschik-Shir (2007)}

Focaliza um elemento de certo conjunto não delimitado pelo contexto, portanto, não descarta os demais elementos.

\section{Exemplo:}

A: Quais de seus amigos foram pra festa?

B: O JOÃO ${ }_{F}$ foi.

\section{- Foco sobreinformativo, proposto nesta pesquisa}

Contrasta a não exaustividade de uma propriedade em relação a determinado elemento, sem necessariamente negá-lo ou descartá-lo e inclui outros elementos pertencentes ao mesmo conjunto do elemento dado.

Exemplo:
A: O João foi pra festa?
B: TODO $\mathrm{MUNDO}_{F}$ foi festa (inclusive o João). 


\section{TIPOS DE TÓPICO}

\section{- Tópico restritivo, de Erteschik-Shir (2007)}

O constituinte que destaca um elemento de um conjunto dado no contexto. Diferentemente dos casos de foco restritivo, que apresentam uma pressuposição de que há pelo um indivíduo com a propriedade em questão, tópico restritivo não carrega esta pressuposição.

Exemplo:

A: Os alunos foram pra festa?

B: O João $T$ foi.

\section{- Tópico parcial, de Büring (1999)}

O falante não responde completamente ao que foi questionado e sim sobre um indivíduo do conjunto em questão.

Exemplo:

A: Que livro os alunos compraram?

B: O João ${ }_{T}$ comprou o de LINGUÍSTICA . $_{\text {. }}$

\section{- Tópico contrastivo, de Büring (1999)}

O falante move a conversação para uma entidade diferente da dada no discurso.

Exemplo:
A: Que livro o João comprou?
B: (Bom, $\mathrm{O} \mathrm{Marcos}_{T}$ comprou o de LINGUÍSTICA $F$. 
BEGHELLI, F. \& STOWELL, T. (1997) Distributivity and Negation: the Syntax of EACH and EVERY. In: A. Szabolcsi (ed.) Ways of Scope Taking. Dordrecht, Kluwer, p. 71-109.

BELLETTI, A. (2004) Aspects of the low IP area. In: Rizzi, L. (ed) The Structure of CP and IP. Oxford: Oxford University Press, p. 16-51.

BÜRING, D. (1999) Topic. In: Bosch, P. \& van der Sandt, R. (eds) Focus - Linguistic, Cognitive, and Computation Perspectives. Cambridge: Cambridge University Press, p. 142-165.

BÜRING, D. (2003) On D-trees, beans, and B-accents. Linguistics \& Philosophy 26 (5): 511 545.

CARLSON, L. (1983) Dialogue Games: An Approach to Discourse Analysis. Reidel, Dordrecht.

CHOMSKY, N. (1971) Deep Structure, Surface Structure and Semantic Interpretation. In: Steinberg, D. \& Jakobovits,lçm,lm, L. (eds.) Semantics: An Interdisciplinary Reader in Philosophy, Linguistics and Psychology. Cambridge: Cambridge University Press, p. 183216.

CHOMSKY, N. (1995) The Minimalist Program. Cambridge, Mass.: MIT Press.

CINQUE, G. \& RIZZI, L. (2008). The Cartography of Syntactic Structures. In: STiL - Studies in Linguistics, CISCL Working Papers, vol 2, p. 43-59.

DAVIDSON, D. (1967) The logical form of action sentences. In: Rescher, N. (ed.) The Logic of Decision and Action. Pittisburgh: University of Pittsburgh Press.

ERTESCHIK-SHIR, N. (1997). The Dynamics of Focus Structure. Cambridge: Cambridge University Press.

ERTESCHIK-SHIR, N. (2007). Information Structure: The Syntax-Discourse Interface. Oxford: Oxford University Press

GAZDAR, G. (1979). Pragmatics: Implicature, Presupposition and Logical Form. New York: Academic Press.

GRICE, H. P. (1975). Logic and conversation. In: Cole, P. \& Morgan, J. (eds.) Syntax and Semantics, vol. 3. New York: Academic Press, p. 41-58.

GROENENDIJK, J. \& STOKHOF, M. (1984) Studies on the Semantics of Questions and the Pragmatics of Answers. Tese de Doutorado, University of Amsterdam.

HALLIDAY, M. A. K. (1967). Notes on Transitivity and Theme in English: Part 2. Journal of Linguistics 3: 199-244. 
HAMBLIN, C. (1973) Questions in Montague English. Foundations of Language 10: 41-53 (Reprinted in Partee. B. (ed.) (1976) Montague Grammar, Texas: University of Texas Press).

HEIM I. \& KRATZER A. (1998) Semantics in Generative Grammar. Oxford: Blackwell Publishers.

HORNSTEIN, N. (1995). Logical Form. Oxford: Blackwell Publishers.

HORNSTEIN, N., NUNES, J. \& GROHMANN, K. (2005) Understanding Minimalism. Cambridge: Cambridge University Press.

JACKENDOFF, R. (1972) Semantics Interpretation in Generative Grammar. Cambridge, MA: MIT Press.

KAYNE, R. S. (1994) The antisymmetry of syntax. Cambridge. Mass: MIT Press

KISS, K. (1998). Identificational Focus versus Information Focus. Language, v. 74 (2): 245273.

KRATZER, A. (2003) The Event Argument and the Semantics of Verbs - Manuscript

MAY, R. (1977) The Grammar of Quantification. Tese de Doutorado. MIT

MAY, R. (1985) Logical Form. Its Structure and Derivation. Cambridge, MA: MIT Press.

MILSARK, G. (1974) Existencial Sentences in English. Tese de Doutorado. MIT

MIOTO, C. (2001). Sobre o sistema CP no Português Brasileiro. Revista Letras 56: 97-139.

MIOTO, C. (2003). Focalização e Quantificação. Revista Letras 61: 169-189.

NEGRÃO, E. V. (1999) O Português Brasileiro: uma língua voltada para o discurso. Tese de Livre Docência. USP.

PARSONS, T. (1990) Events in the Semantics of English. Cambridge: MIT Press.

PIERREHUMBERT, J. \& HIRSCHBERG J. (1990) The meaning of intonational contours in the interpretation of discourse. In: Cohen, P.; Morgan, J. \& Pollack M. (eds.) Intentions in Communication. Cambridge, MA: MIT Press, p. 271-311.

POLLOCK, J. (1989) Verb Movement, Universal Grammar, and the Structure of IP. Linguistic Inquiry 20: 365-424.

QUAREZEMIN, S. (2009) Estratégias de Focalização no Português Brasileiro. Tese de Doutorado. UFSC.

REINHART, T. (1981) Pragmatics and Linguistics: An Analysis of Sentence Topics. Philosophica 27: 53-94.

RIZZI, L. (1997) The fine structures of left periphery. In: Haegeman, L. (ed.) Elements of Grammar. Dordrecht: Kluwer Academic Publishers, p. 281-337.

ROBERTS, C. (1996) Information Structure in Discourse: Towards an Integrated Formal Theory of Pragmatics. In: Yoon, J. H. \& Kathol, A. (eds.) OSU Working Papers in 
Linguistics 49: Papers in Semantics, pp. 91-136.

ROOTH, M. (1985) Association with Focus. Tese de Doutorado. University of Massachusetts, Amherst.

SCHWARZSCHILD, R. (1999) GiVENness, AvoidF and Other Constraints on the Placement of Accent. Natural Language Semantics 7(2), 141-177.

STALNAKER, R. (1978). Assertion. In: Cole, P. (ed.) Pragmatics - Syntax \& Semantics, Vol. 9. New York: Academic Press, p. 315-332.

von STECHOW, A. (1989) Focusing and backgrounding operators. Arbeitspapier 6, Fachgruppe Sprachwissenschaft, Universität Konstanz. 